FY 2005

\title{
INTERIOR PERMANENT MAGNET RELUCTANCE MACHINE WITH BRUSHLESS FIELD EXCITATION
}

Prepared by:

Oak Ridge National Laboratory

Mitch Olszewski, Program Manager

Submitted to:

Energy Efficiency and Renewable Energy

FreedomCAR and Vehicle Technologies

Vehicle Systems Team

Susan A. Rogers, Technology Development Manager

September 2005 
NATIONAL LABORATORY

MANAGED BY UT-BATTELLE

FOR THE DEPARTMENT OF ENERGY

\section{INTERIOR PERMANENT MAGNET RELUCTANCE MACHINE WITH BRUSHLESSS FIELD EXCITATION}

\author{
R. H. Wiles \\ C. L. Coomer \\ J. S. Hsu
}

Publication Date: September 2005

Prepared by the

\author{
OAK RIDGE NATIONAL LABORATORY \\ Oak Ridge, Tennessee 37831 \\ managed by \\ UT-BATTELLE, LLC \\ for the \\ U.S. DEPARTMENT OF ENERGY \\ Under contract DE-AC05-00OR22725
}


This report was prepared as an account of work sponsored by an agency of the United States Government. Neither the United States Government nor any agency thereof, nor any of their employees, makes any warranty, express or implied, or assumes any legal liability or responsibility for the accuracy, completeness, or usefulness of any information, apparatus, product, or process disclosed, or represents that its use would not infringe privately owned rights. Reference herein to any specific commercial product, process, or service by trade name, trademark, manufacturer, or otherwise, does not necessarily constitute or imply its endorsement, recommendation, or favoring by the United States Government or any agency thereof. The views and opinions of authors expressed herein do not necessarily state or reflect those of the United States Government or any agency thereof. 


\section{TABLE CONTENTS}

Page

LIST OF FIGURES ……........................................................................................ iii

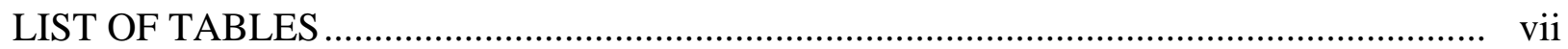

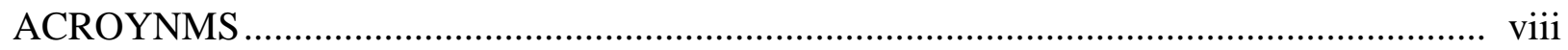

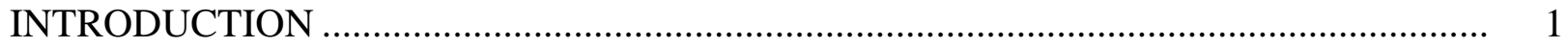

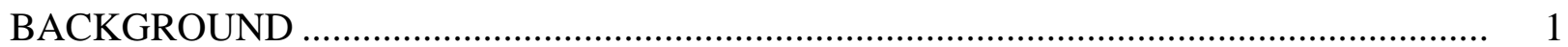

DESIGN DESCRIPTION OF THE RIPM-BFE MACHINE .................................................. 1

PERFORMANCE DATA OF THE 0.100 INCH MAGNET ROTOR....................................... 9

PERFORMANCE DATA OF THE 0.240 INCH MAGNET ROTOR.................................... 20

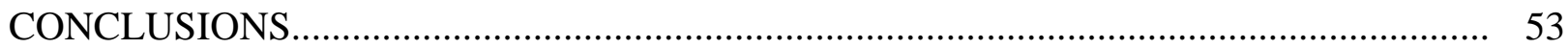

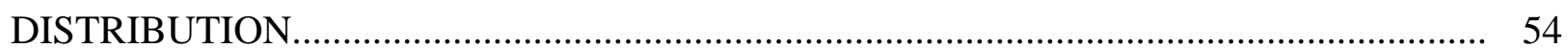




\section{LIST OF FIGURES}

Figure

Page

1

RIPM-BFE rotor lamination

RIPM-BFE stator and THS II stator .....

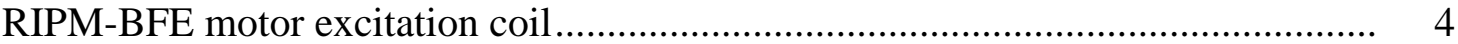

RIPM-BFE rotor

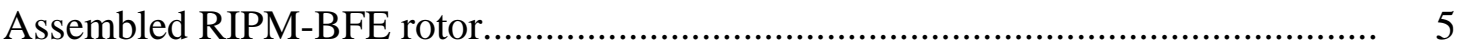

Comparison of THSII rotor to RIPM-BFE rotor ............................................ 6

RIPM-BFE motor housing with excitation coil and spray ring ............................. 7

Air-gap flux density distribution of RIPM-BFE 2.5 inch core-length motor ........... 8

Air-gap flux density distribution of THSII 3.3 inch core-length motor ................... 8

10 Back-emf at 2000 rpm, phase-to-neutral reading with no field weakening/ enhancement

11 Back-emf at 1500 rpm, phase-to-neutral reading with no field weakening/ enhancement

Back-emf at 1000 rpm, phase-to-neutral reading with no field weakening/ enhancement

Back-emf at 500 rpm, phase-to-neutral reading with no field weakening/

enhancement

Back-emf with field weakening $500 \mathrm{rpm}, 200 \mathrm{Vdc}$, and 4.5 Adc

Back-emf with field weakening $1000 \mathrm{rpm}, 200 \mathrm{Vdc}$, and 4.49 Adc

Back-emf with field weakening 1000 rpm, 113.98 Vdc, and 2.5 Adc .................... 12

Back-emf with field weakening 1500 rpm, $200 \mathrm{Vdc}$, and 4.51 Adc

Back-emf with field weakening 1500 rpm, 113.74 Vdc, and 2.56 Adc .......

Back-emf with field weakening 2000 rpm, 200 Vdc, and 4.54 Adc.

Back-emf with field weakening 2000 rpm, 113.97 Vdc, and 2.57 Adc ......

Back-emf with field enhancement 500 rpm, $200 \mathrm{Vdc}$, and 4.8 Adc....................... 15

Back-emf with field enhancement 500 rpm, 102 Vdc, and 2.4 Adc.

Back-emf with field enhancement 1000 rpm, $200 \mathrm{Vdc}$, and 4.7 Adc...................... 16

Back-emf with field enhancement 1000 rpm, $104 \mathrm{Vdc}$, and 2.5 Adc.....

Back-emf with field enhancement 1500 rpm, 200 Vdc, and 4.7 Adc...................... 17

Back-emf with field enhancement 1500 rpm, $101 \mathrm{Vdc}$, and 2.3 Adc...................... 17

Back-emf with field enhancement 2000 rpm, 200 Vdc, and 4.7 Adc...................... 18

Back-emf with field enhancement 2000 rpm, 103 Vdc, and 2.4 Adc.

290.240 in. thick magnet rotor back-emf at $500 \mathrm{rpm}$ without field weakening/enhancement....

$30 \quad 0.240$ in. thick magnet rotor back-emf at $1000 \mathrm{rpm}$ without field weakening/enhancement

$310.240 \mathrm{in}$. thick magnet rotor back-emf at $1500 \mathrm{rpm}$ without field weakening/enhancement

$320.240 \mathrm{in}$. thick magnet rotor back-emf at $2000 \mathrm{rpm}$ without field weakening/enhancement

$330.240 \mathrm{in}$. thick magnet rotor back-emf at $500 \mathrm{rpm}$ with field weakening at 1 Adc. 


\section{LIST OF FIGURES (cont'd)}

Figure

Page

340.240 in. thick magnet rotor back-emf at $500 \mathrm{rpm}$ with field weakening at 2 Adc

350.240 in. thick magnet rotor back-emf at $500 \mathrm{rpm}$ with field weakening at 3 Adc

$36 \quad 0.240$ in. thick magnet rotor back-emf at $500 \mathrm{rpm}$ with field weakening at 4 Adc.....

$37 \quad 0.240 \mathrm{in}$. thick magnet rotor back-emf at $500 \mathrm{rpm}$ with field weakening at 5 Adc 25 0.240 in. thick magnet rotor back-emf at $1000 \mathrm{rpm}$ with field weakening at 1 Adc

$390.240 \mathrm{in}$. thick magnet rotor back-emf at $1000 \mathrm{rpm}$ with field weakening at 2 Adc

0.240 in. thick magnet rotor back-emf at $1000 \mathrm{rpm}$ with field weakening at 3 Adc

$410.240 \mathrm{in}$. thick magnet rotor back-emf at $1000 \mathrm{rpm}$ with field weakening at 4 Adc.

$42 \quad 0.240$ in. thick magnet rotor back-emf at $1000 \mathrm{rpm}$ with field weakening at 5 Adc.

$43 \quad 0.240 \mathrm{in}$. thick magnet rotor back-emf at $1500 \mathrm{rpm}$ with field weakening at 1 Adc.....

$44 \quad 0.240$ in. thick magnet rotor back-emf at $1500 \mathrm{rpm}$ with field weakening at 2 Adc

0.240 in. thick magnet rotor back-emf at $1500 \mathrm{rpm}$ with field weakening at 3 Adc

0.240 in. thick magnet rotor back-emf at $1500 \mathrm{rpm}$ with field weakening at 4 Adc

$47 \quad 0.240 \mathrm{in}$. thick magnet rotor back-emf at $1500 \mathrm{rpm}$ with field weakening at 5 Adc

$48 \quad 0.240 \mathrm{in}$. thick magnet rotor back-emf $2000 \mathrm{rpm}$ with field weakening at 1 Adc

$49 \quad 0.240$ in. thick magnet rotor back-emf $2000 \mathrm{rpm}$ with field weakening at 2 Adc

$50 \quad 0.240$ in. thick magnet rotor back-emf $2000 \mathrm{rpm}$ with field weakening at 3 Adc.

$510.240 \mathrm{in}$. thick magnet rotor back-emf $2000 \mathrm{rpm}$ with field weakening at 4 Adc.

$520.240 \mathrm{in}$. thick magnet rotor back-emf $2000 \mathrm{rpm}$ with field weakening at 5 Adc.

530.240 in. thick magnet rotor back-emf at $500 \mathrm{rpm}$ with field enhancement at 1 Adc

$54 \quad 0.240$ in. thick magnet rotor back-emf at $500 \mathrm{rpm}$ with field enhancement at 2 Adc. 


\section{LIST OF FIGURES (cont'd)}

Figure

Page

$55 \quad 0.240 \mathrm{in}$. thick magnet rotor back-emf at $500 \mathrm{rpm}$ with field enhancement at 3 Adc....

$56 \quad 0.240$ in. thick magnet rotor back-emf at $500 \mathrm{rpm}$ with field enhancement at 4 Adc

$57 \quad 0.240$ in. thick magnet rotor back-emf at $500 \mathrm{rpm}$ with field enhancement at 5 Adc

580.240 in. thick magnet rotor back-emf at $1000 \mathrm{rpm}$ with field enhancement at 1 Adc

$590.240 \mathrm{in}$. thick magnet rotor back-emf at $1000 \mathrm{rpm}$ with field enhancement at 2 Adc

$60 \quad 0.240$ in. thick magnet rotor back-emf at $1000 \mathrm{rpm}$ with field enhancement at 3 Adc

610.240 in. thick magnet rotor back-emf at $1000 \mathrm{rpm}$ with field enhancement at 4 Adc

620.240 in. thick magnet rotor back-emf at $1000 \mathrm{rpm}$ with field enhancement at 5 Adc.....

$630.240 \mathrm{in}$. thick magnet rotor back-emf at $1500 \mathrm{rpm}$ with field enhancement at 1 Adc.

640.240 in. thick magnet rotor back-emf at $1500 \mathrm{rpm}$ with field enhancement at 2 Adc.....

$650.240 \mathrm{in}$. thick magnet rotor back-emf at $1500 \mathrm{rpm}$ with field enhancement at 3 Adc

$66 \quad 0.240 \mathrm{in}$. thick magnet rotor back-emf at $1500 \mathrm{rpm}$ with field enhancement at 4 Adc

670.240 in. thick magnet rotor back-emf at $1500 \mathrm{rpm}$ with field enhancement at 5 Adc

$68 \quad 0.240$ in. thick magnet rotor back-emf at $2000 \mathrm{rpm}$ with field enhancement at 1 Adc

690.240 in. thick magnet rotor back-emf at $2000 \mathrm{rpm}$ with field enhancement at 2 Adc.....

$70 \quad 0.240 \mathrm{in}$. thick magnet rotor back-emf at $2000 \mathrm{rpm}$ with field enhancement at 3 Adc

710.240 in. thick magnet rotor back-emf at $2000 \mathrm{rpm}$ with field enhancement at 4 Adc....

$720.240 \mathrm{in}$. thick magnet rotor back-emf at $2000 \mathrm{rpm}$ with field enhancement at 5 Adc

73 RIPM-BFE locked rotor torque vs. rotor angular position without field enhancement/weakening.

74 RIPM-BFE locked rotor torque vs. rotor angular position with 5 amps field enhancement

75 RIPM-BFE locked rotor torque vs rotor angular position with 5 amps field weakening 


\section{LIST OF FIGURES (cont'd)}

$\begin{array}{ll}\text { Figure } & \text { Page }\end{array}$

76 Comparison of PM torque components and peak-torque components between 2.5 in. ORNL machine and 3.3 in. THSII machine 


\section{LIST OF TABLES}

Table

Page

1 Mechanical losses on 0.100 in. magnet rotor with field weakening at $2000 \mathrm{rpm}$

2 Mechanical losses on 0.100 in. magnet rotor with field enhancement at $2000 \mathrm{rpm}$

3 Mechanical losses on 0.240 in. magnet rotor at 500-2000 rpm without field enhancement/weakening....

4 Locked rotor torque of RIPM-BFE motor at 50 amps dc stator current.

5 Locked rotor torque of RIPM-BFE motor at 100 amps dc stator current.

6 Locked rotor torque of RIPM-BFE motor at 150 amps dc stator current.....

Locked rotor torque of RIPM-BFE motor at 200 amps dc stator current

8 Locked rotor torque of RIPM-BFE motor at 250 amps dc stator current

9 Locked rotor torque of RIPM-BFE motor at 50 amps dc stator current with 5 amps field excitation (enhance)....

Locked rotor torque of RIPM-BFE motor at 100 amps dc stator current with 5 amps field excitation (enhance)....

Locked rotor torque of RIPM-BFE motor at 150 amps dc stator current

with 5 amps field excitation (enhance)....

12 Locked rotor torque of RIPM-BFE motor at 200 amps dc stator current with 5 amps field excitation (enhance)...

13 Locked rotor torque of RIPM-BFE motor at 250 amps dc stator current

with 5 amps field excitation (enhance)

14 Locked rotor torque of RIPM-BFE motor at 50 amps dc stator current with 5 amps field excitation (weaken)

15 Locked rotor torque of RIPM-BFE motor at 100 amps dc stator current with 5 amps field excitation (weaken)

16 Locked rotor torque of RIPM-BFE motor at 150 amps dc stator current with 5 amps field excitation (weaken)....

17 Locked rotor torque of RIPM-BFE motor at 200 amps dc stator current with 5 amps field excitation (weaken).....

Locked rotor torque of RIPM-BFE motor at 250 amps dc stator current with 5 amps field excitation (weaken) 


\section{ACRONYMS}

amp

dc

emf

IPM

ORNL

PM

rpm

THSII

RIPM-BFE ampere
direct current
electromotive force
interior permanent magnet

Oak Ridge National Laboratory permanent magnet revolutions per minute

Toyota Prius Hybrid System (2005) Reluctance Interior Permanent Magnet with Brushless Field Excitation 


\section{INTRODUCTION}

In a conventional permanent magnet (PM) machine, the air-gap flux produced by the PM is fixed. It is difficult to enhance the air-gap flux density due to limitations of the PM in a seriesmagnetic circuit. However, the air-gap flux density can be weakened by using power electronic field weakening to the limit of demagnetization of the PMs. This paper presents the test results of controlling the PM air-gap flux density through the use of a stationary brushless excitation coil in a reluctance interior permanent magnet with brushless field excitation (RIPM-BFE) motor. Through the use of this technology the air-gap flux density can be either enhanced or weakened. There is no concern with demagnetizing the PMs during field weakening. The leakage flux of the excitation coil through the PMs is blocked. The prototype motor built on this principle confirms the concept of flux enhancement and weakening through the use of excitation coils.

\section{BACKGROUND}

The RIPM-BFE was invented at the Oak Ridge National Laboratory (ORNL). It offers a high torque per ampere (amp) by using a brushless excitation coil to enhance the flux. The motor eliminates the system need for a dc/dc boost converter at medium and high speeds. The core loss of the motor is low because the flux can be weakened through the excitation coil.

\section{DESIGN DESCRIPTION OF THE RIPM-BFE MACHINE}

The electro-mechanical simulation was completed on the RIPM-BFE showing positive results on the overall design characteristics as well as the ability to weaken/enhance the magnetic flux of the machine. Two simulations were performed, one with a magnet thickness of 0.100 in. to simulate a more cost effective way to produce the motor in a high volume manufacturing environment. The second simulation was made with the same magnet material but a magnet of 0.240 in. thickness which would produce a higher-torque output on the machine, but would be more costly to produce in a high volume manufacturing environment. Engineering drawings were completed and sent to both ORNL and outside fabrication facilities for manufacturing.

Magnets for the RIPM-BFE rotor were fabricated by vendors outside of ORNL. The two different magnet thicknesses were specified and two different rotors were fabricated with the same rotor punchings.

The rotor laminations were designed to closely match the electro-mechanical simulated lamination design as seen in Fig. 1. These laminations were fabricated from 0.014 in. thick coated silicon steel (29 Ga. M19 C5 non-oriented fully processed). The laminations were fabricated with a diameter identical to that of the 2005 Toyota Prius Hybrid System (THSII) drive system motor. The rotor inner diameter was modified from that of the Prius in order to incorporate the magnets. 


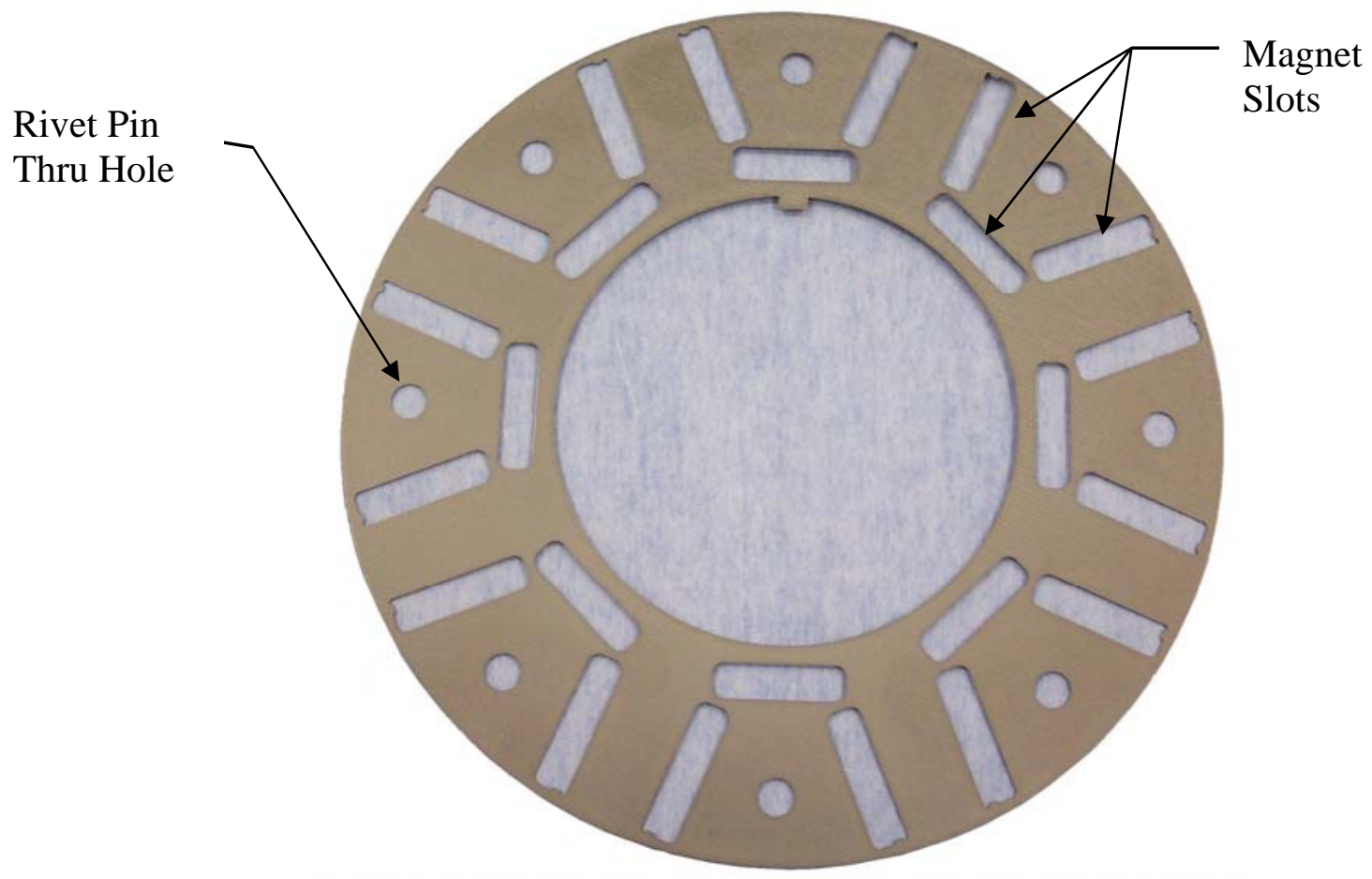

Fig 1. RIPM-BFE rotor lamination.

The stator used in the RIPM-BFE is a thinner version of the THSII traction drive motor as seen in Fig. 2. The stator lamination stack was reduced to a final thickness of 2.5 inches. The stator was re-wound and inductance and resistance measurements were recorded between each phase of the windings. This would ensure an electrically balanced stator for use in the RIPM-BFE machine.

The excitation coils were fabricated at ORNL. Each of the two coils were fabricated from 20 gauge class " $\mathrm{H}$ " magnet wire and contained 880 turns each. To check the electrical balance of each coil, a resistive measurement was taken. The coils had a resistance of 19.30 and 19.37 ohms respectively. Figure 3 shows the finished excitation coils. 


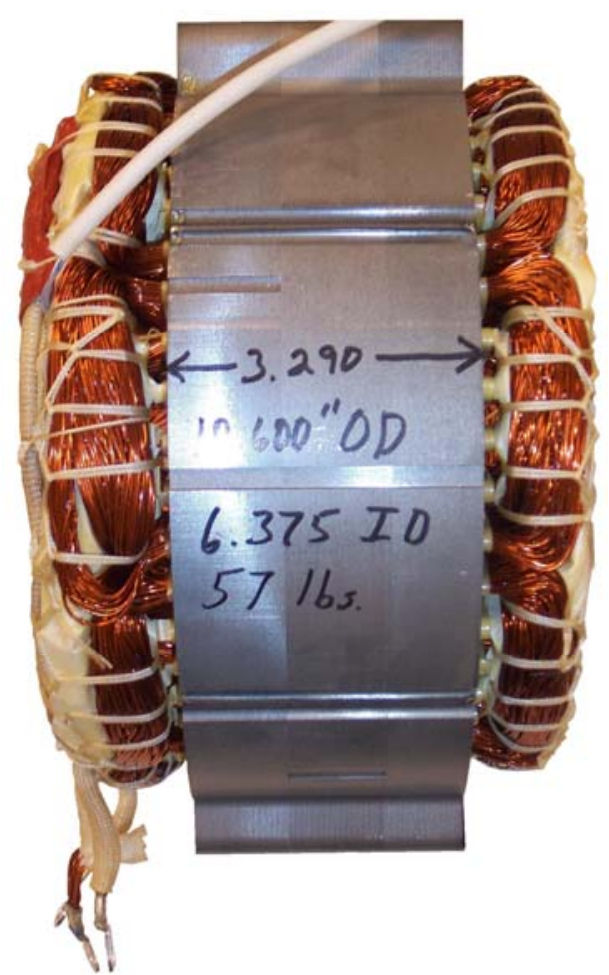

THSII stator

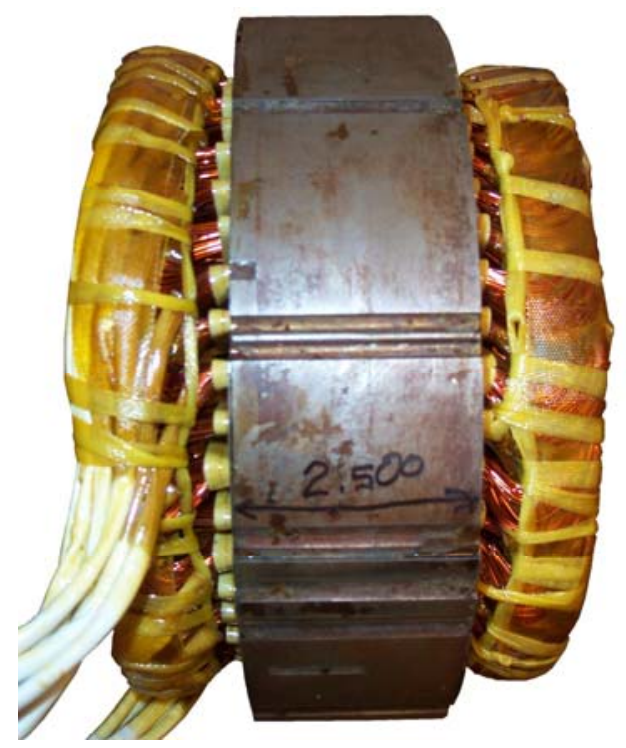

RIPM-BFE stator

Fig. 2. RIPM-BFE stator and THSII stator. 

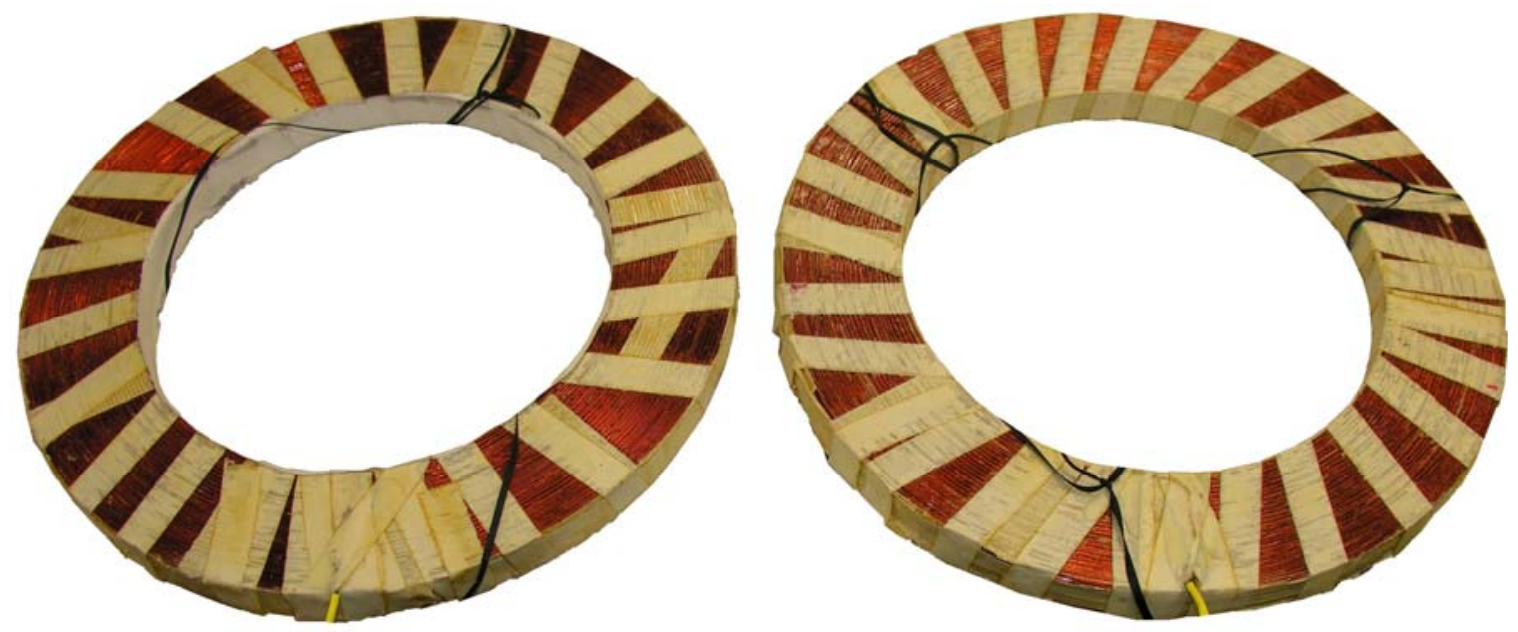

Fig. 3. RIPM-BFE motor excitation coils.

The rotor laminations were placed over the rotor hub and mechanically fastened to the hub using the aluminum "spider" shown in Fig. 4. Four non-PM pole pieces were placed equally spaced around each face of the rotor in the spider slots (Fig. 4). Additionally, the laminations were compressed together using a non-PM pole piece and a "rivet-pin". This pin passed through the laminations and was held in position with screws passing through the non-PM pole piece. The 0.100 in. thick pole magnets were placed at the locations shown in Fig. 4 and then held in position with the magnet retaining ring (see Fig. 5).

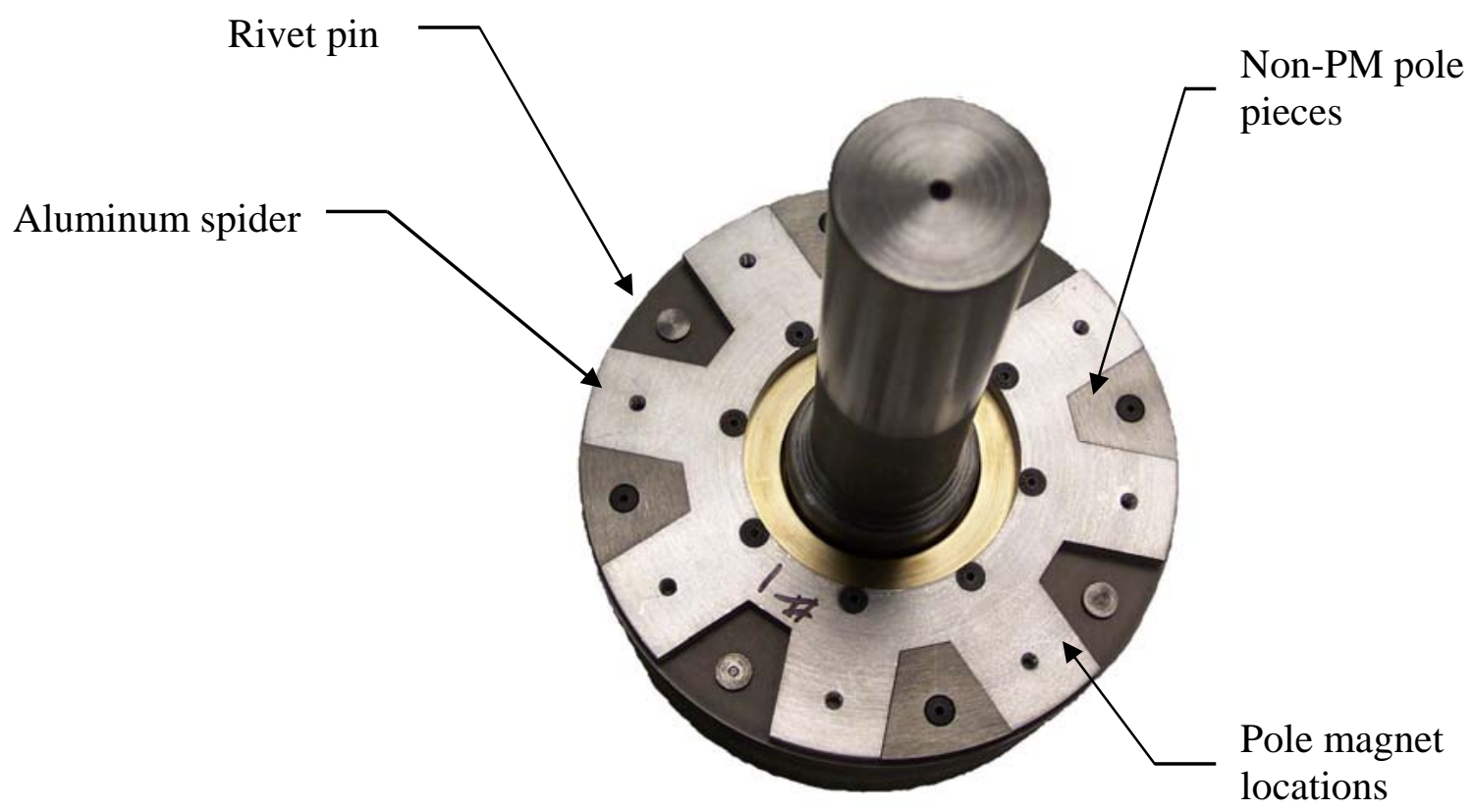

Fig. 4. RIPM-BFE rotor. 


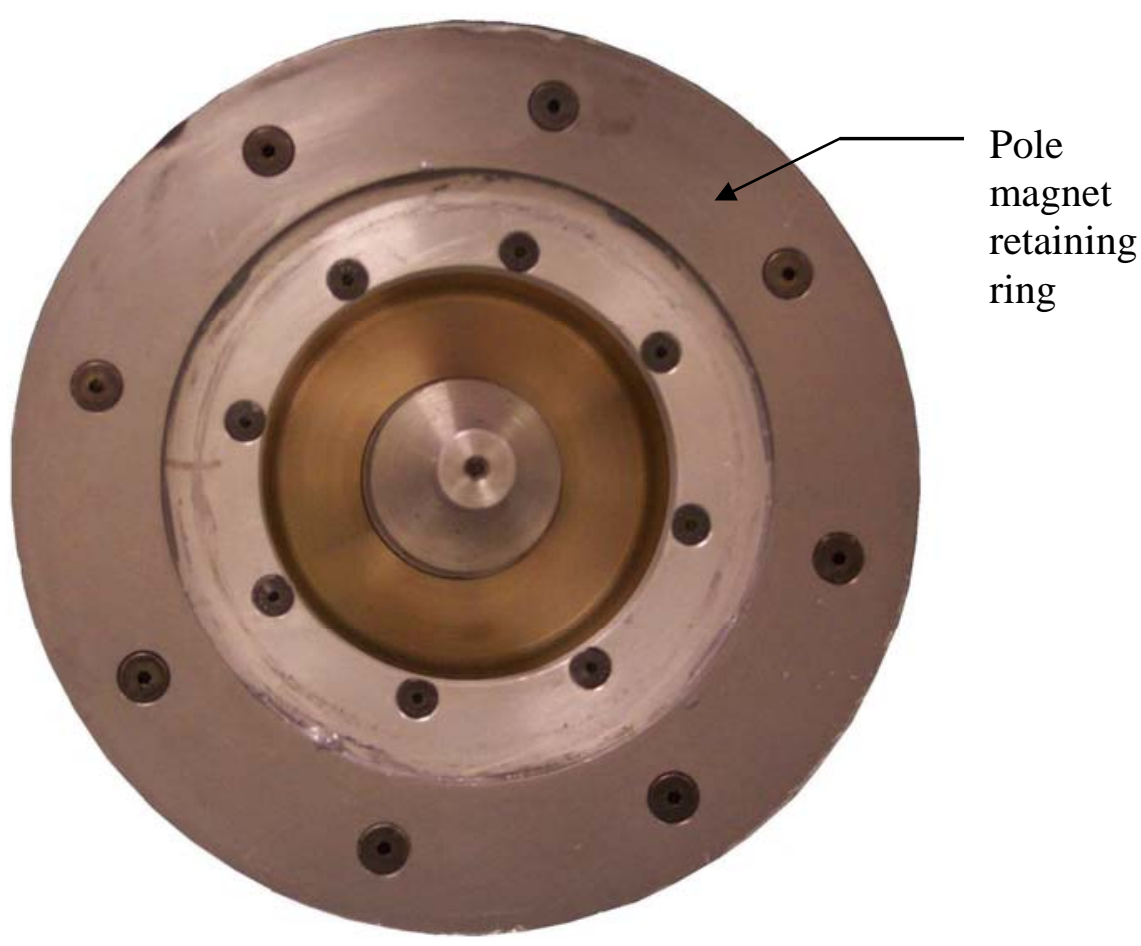

Fig. 5. Assembled RIPM-BFE rotor.

The 0.100 in. thick magnets were placed axially in the lamination slots and all side-pole and axial-lamination magnets were fixed in place with Master Bond Supreme 10HT epoxy. The epoxy was baked at $100^{\circ} \mathrm{C}$ for a minimum of 4 hours to facilitate the curing process but not at a high enough temperature to de-magnetize the PMs. Once the rotor was assembled, it was returned to the fabrication shop and each face of the rotor was trued. Non-magnetic material was machined and used as a retaining ring and placed around the circumference of each of the rotor faces with a $0.010 \mathrm{in}$. interference fit. This ring was used to prevent the pole magnets from being slung out in the event that the epoxy failed during operation. Mechanical measurements were made at each of the eight mechanical fastening positions and recorded. The mean thickness of the assembled rotor was 3.515 inches. See Fig. 6 for a comparison of the RIPM-BFE rotor to the THSII rotor. 


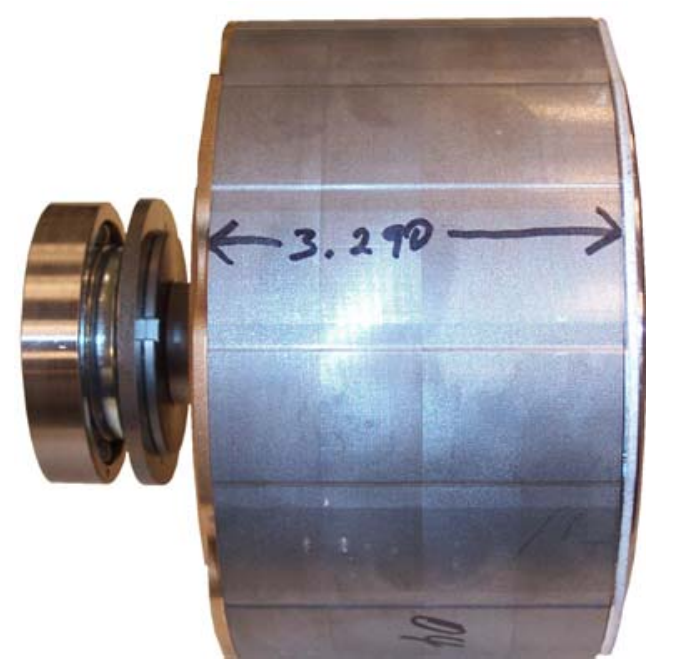

THSII rotor

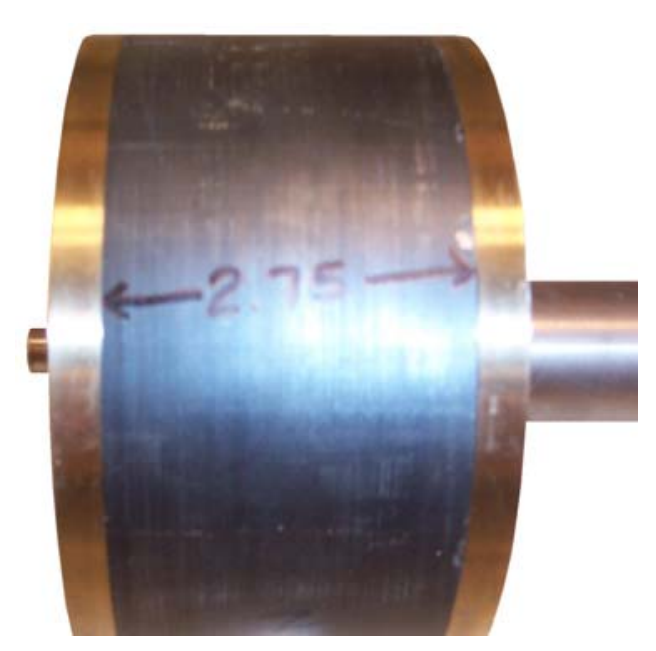

RIPM-BFE rotor

Fig. 6. Comparison of THSII rotor to RIPM-BFE rotor.

The motor housings were assembled with spray rings mounted along the inside diameter at the top edge of both the excitation coil and the stator windings as shown in Fig. 7. These spray rings will enable cooling oil to be pumped through the motor and sprayed directly onto both the excitation coil as well as the stator windings. The cooling oil will then be gravity fed to the bottom of the motor and pumped through a heat exchanger. Future tests will incorporate R134a as a coolant in the heat exchanger for cooling the oil, which is utilized to cool the windings 


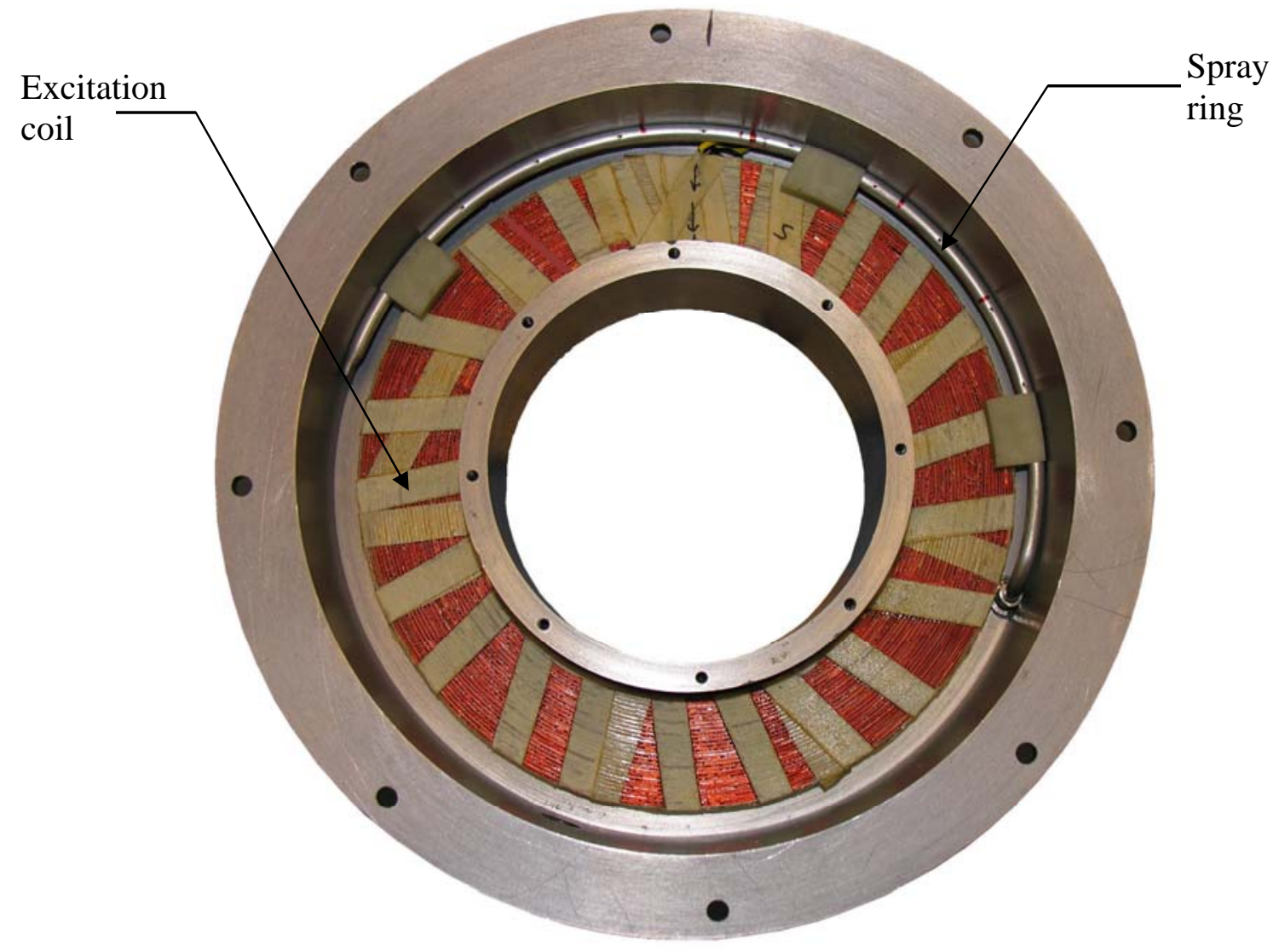

Fig. 7. RIPM-BFE motor housing with excitation coil and spray ring.

After inserting the stator and rotor into the motor housing, the radial gap between the two was measured. A total of 0.028 in. of radial gap was present. Gauss measurements were taken to record the radial air-gap magnetic flux at each stator tooth. These measurements revealed that the rotor magnetism was uniform and all magnets were in their proper orientation. The following figures show the comparison of the air-gap flux densities between the ORNL 0.240 in. thick magnet motor without field excitation and the THSII motor. The maximum air-gap flux density of the ORNL motor is 1.27 Tesla which is 1.63 times the THSII's 0.78 Tesla flux density. The axial air gap was measured between the magnetic retaining ring on the rotor face and the motor housing. Each side of the rotor had an air gap of 0.067 inches. Figures 8 and 9 represent the air-gap flux density of the ORNL RIPM-BFE motor and the THSII motor. 


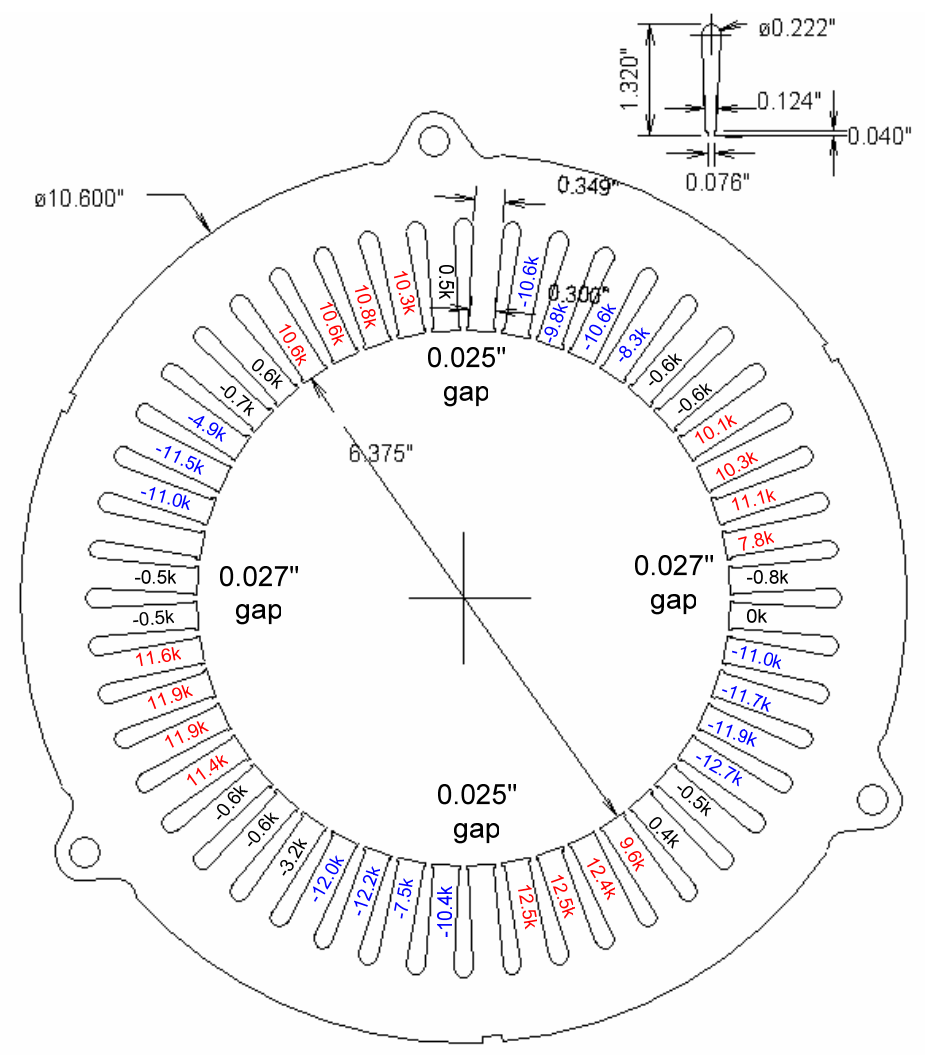

Fig. 8. Air-gap flux density distribution of RIPM-BFE 2.5 in. core-length motor.

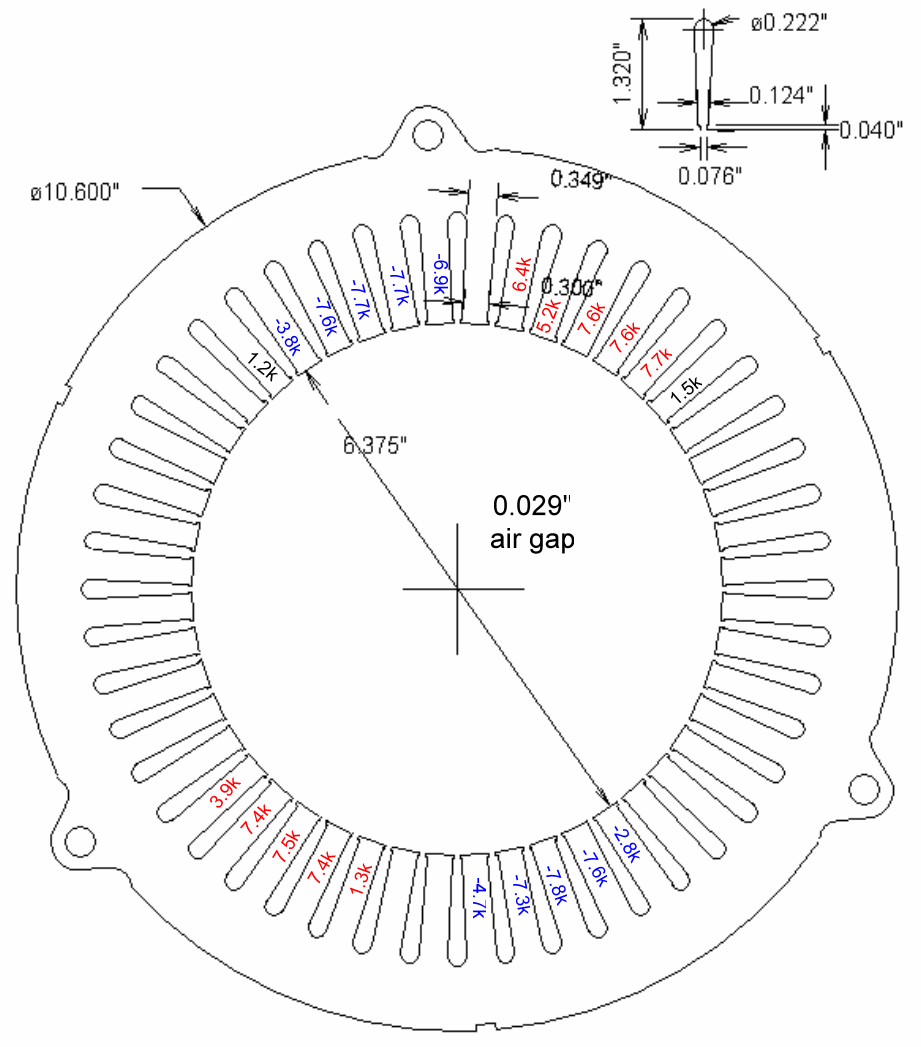

Fig. 9. Air-gap flux density distribution of THSII $3.3 \mathrm{in}$. core-length motor. 


\section{PERFORMANCE DATA OF THE O.100 INCH MAGNET ROTOR}

The RIPM-BFE motor containing the 0.100 in. thick magnet rotor was instrumented to record the back-electromotive force (emf) of each phase of the motor. Each phase was read from phase to neutral. The motor was coupled to the dynamometer and driven at revolutions per minute (rpm) set-points of 500,1000,1500, and 2000. The back-emf was measured on each phase of the motor and the results were recorded. These measurements will be used for checking demagnetization in the future. Back-emf was also recorded at each rpm set-point while both "enhancing” and "weakening” the magnetic field. The test parameters for each enhancement and weakening measurement were: 500, 1000, 1500, and 2000 rpm; 2.5 Adc; and 5.0 Adc or a maximum of $200 \mathrm{Vdc}$. Additionally, the mechanical losses were recorded (in Nm) at 1.0 Adc increments up to 5.0 Adc or a maximum of $200 \mathrm{Vdc}$. The mechanical losses were recorded at $2000 \mathrm{rpm}$ in both the enhancement and weakening state. Data recorded is presented in Figs. 1028.

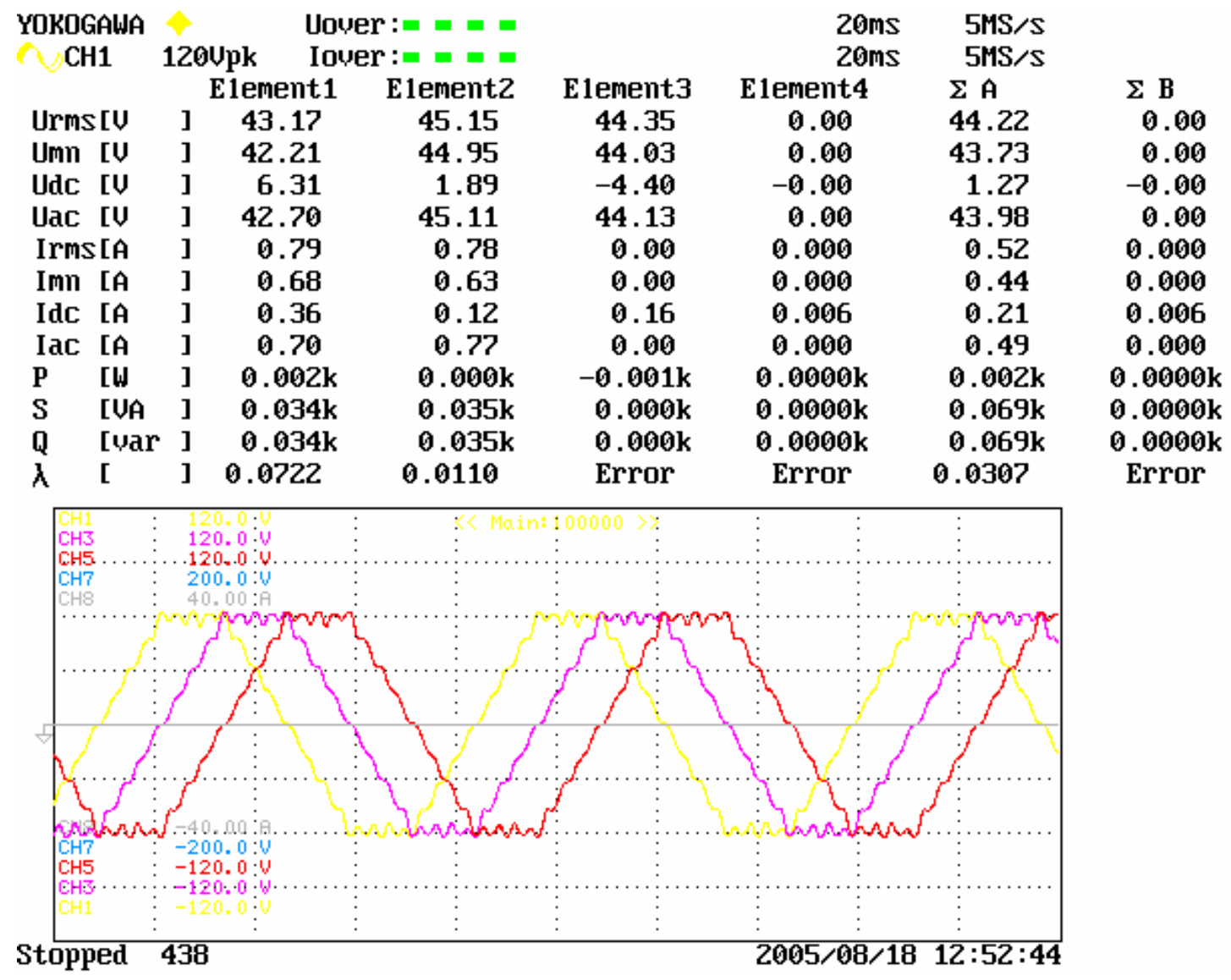

Fig. 10. Back-emf at 2000 rpm, phase-to-neutral reading with no field weakening/enhancement. 


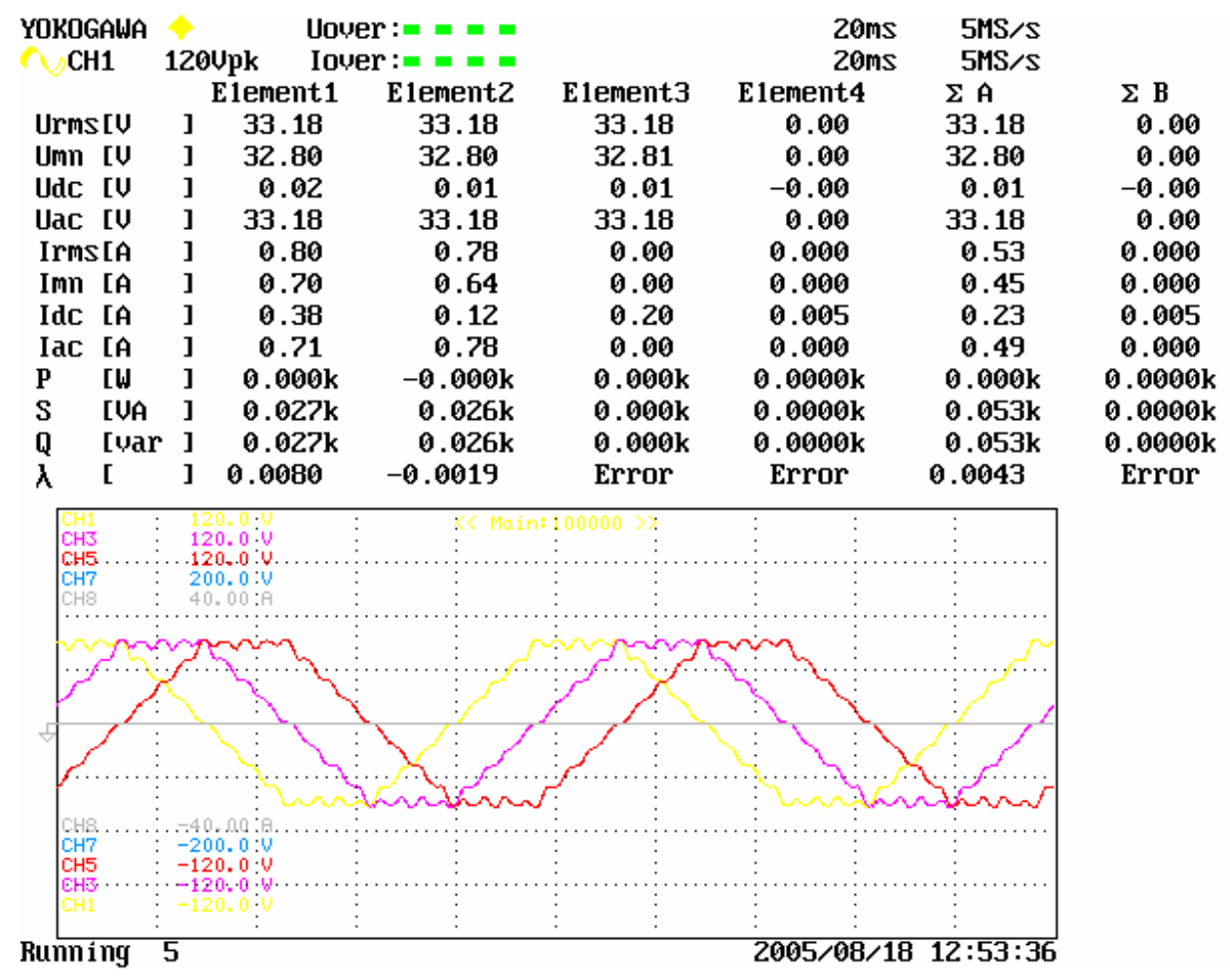

Fig. 11. Back-emf at 1500 rpm, phase-to-neutral reading with no field weakening/enhancement.

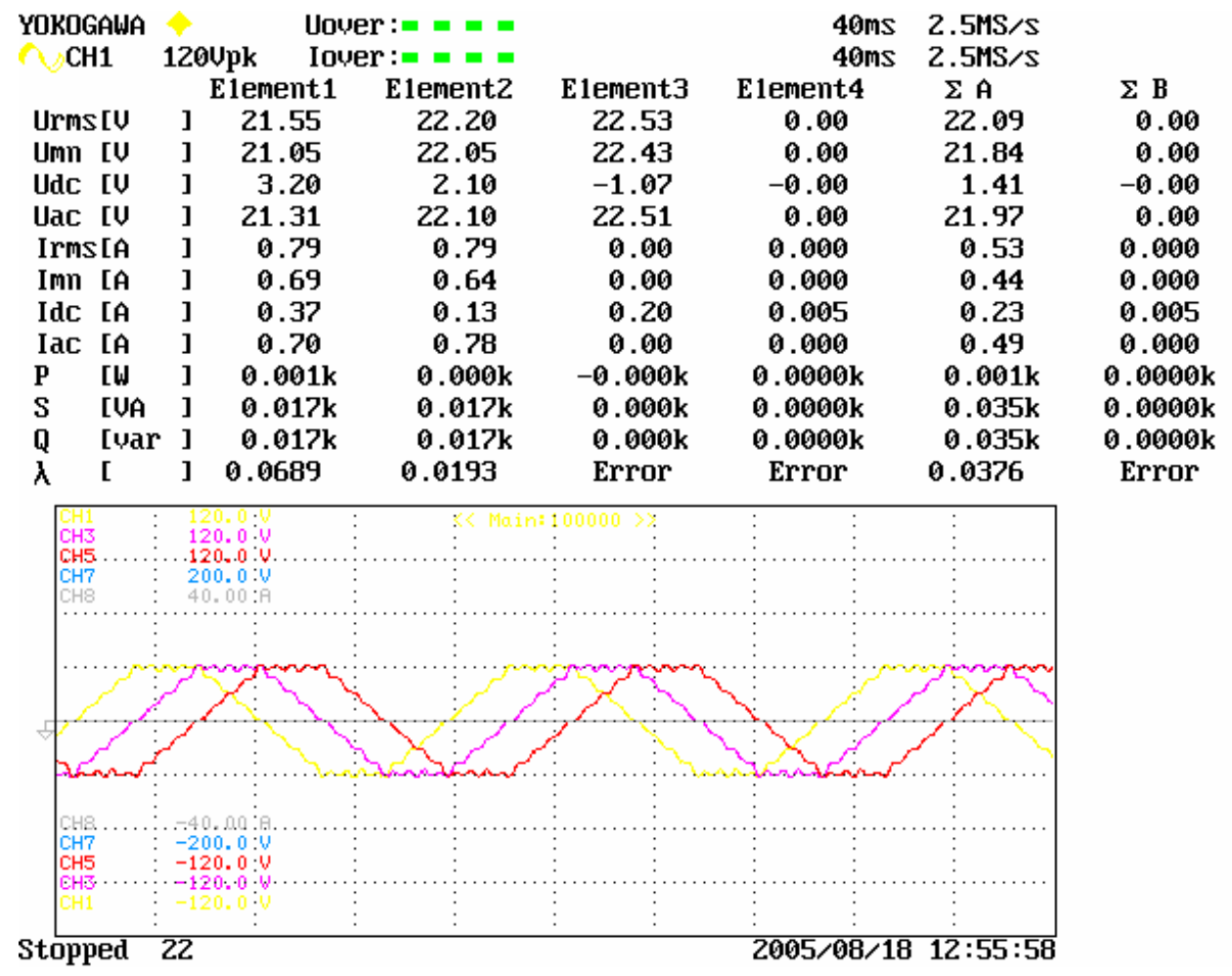

Fig. 12. Back-emf at 1000 rpm, phase-to-neutral reading with no field weakening/enhancement. 


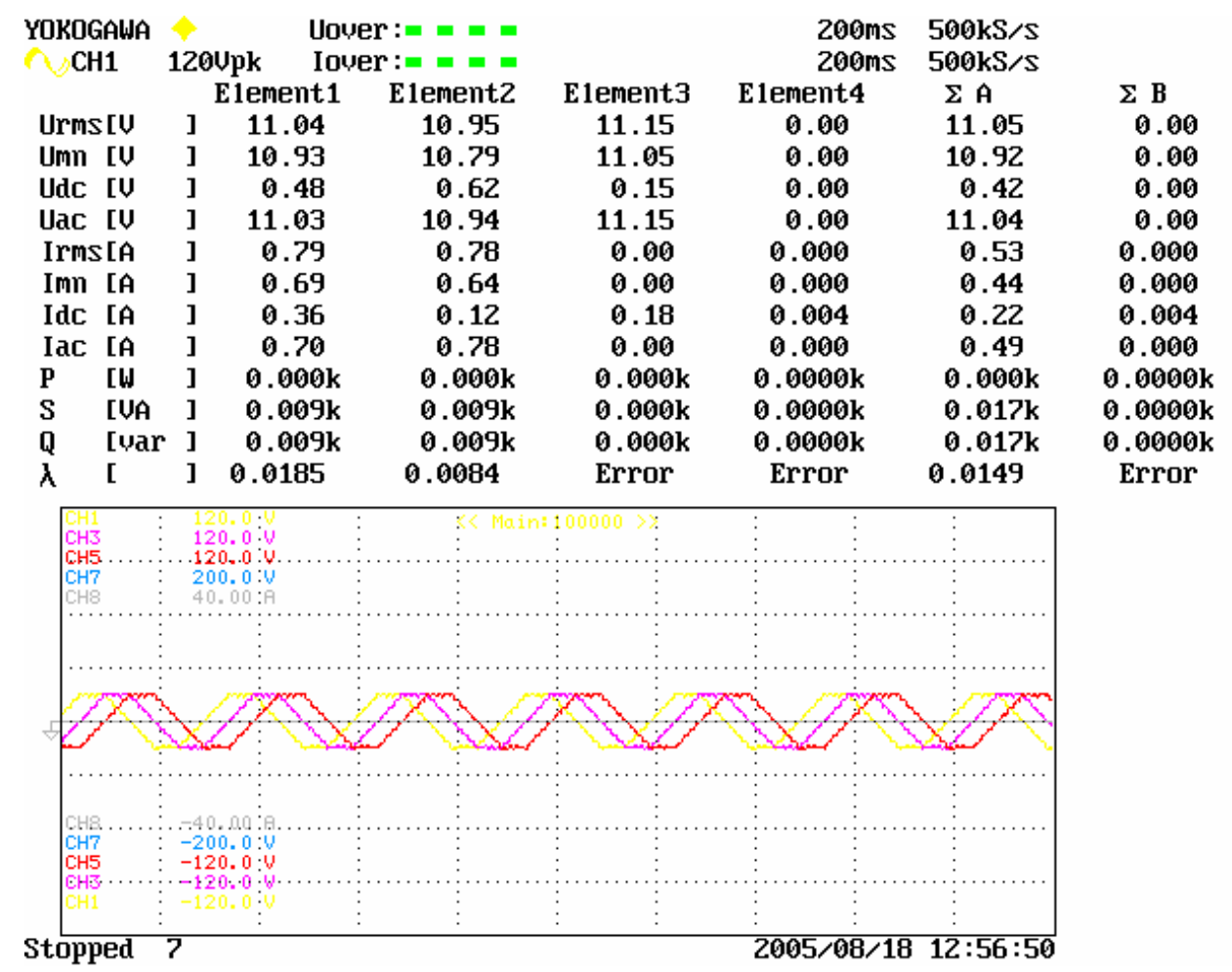

Fig. 13. Back-emf at 500 rpm, phase-to-neutral reading with no field weakening/enhancement.

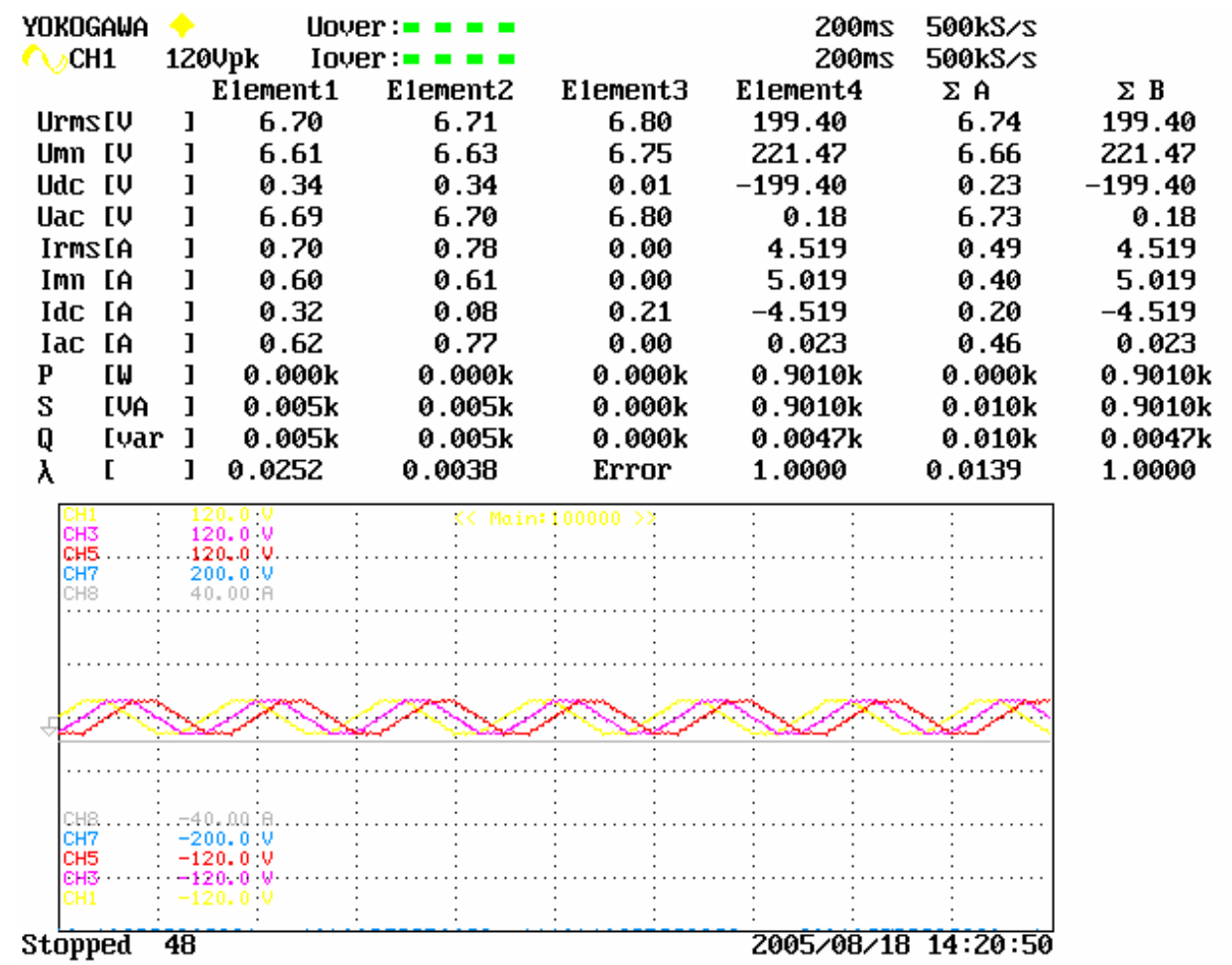

Fig. 14. Back-emf with field weakening 500 rpm, 200 Vdc, and 4.5 Adc. 


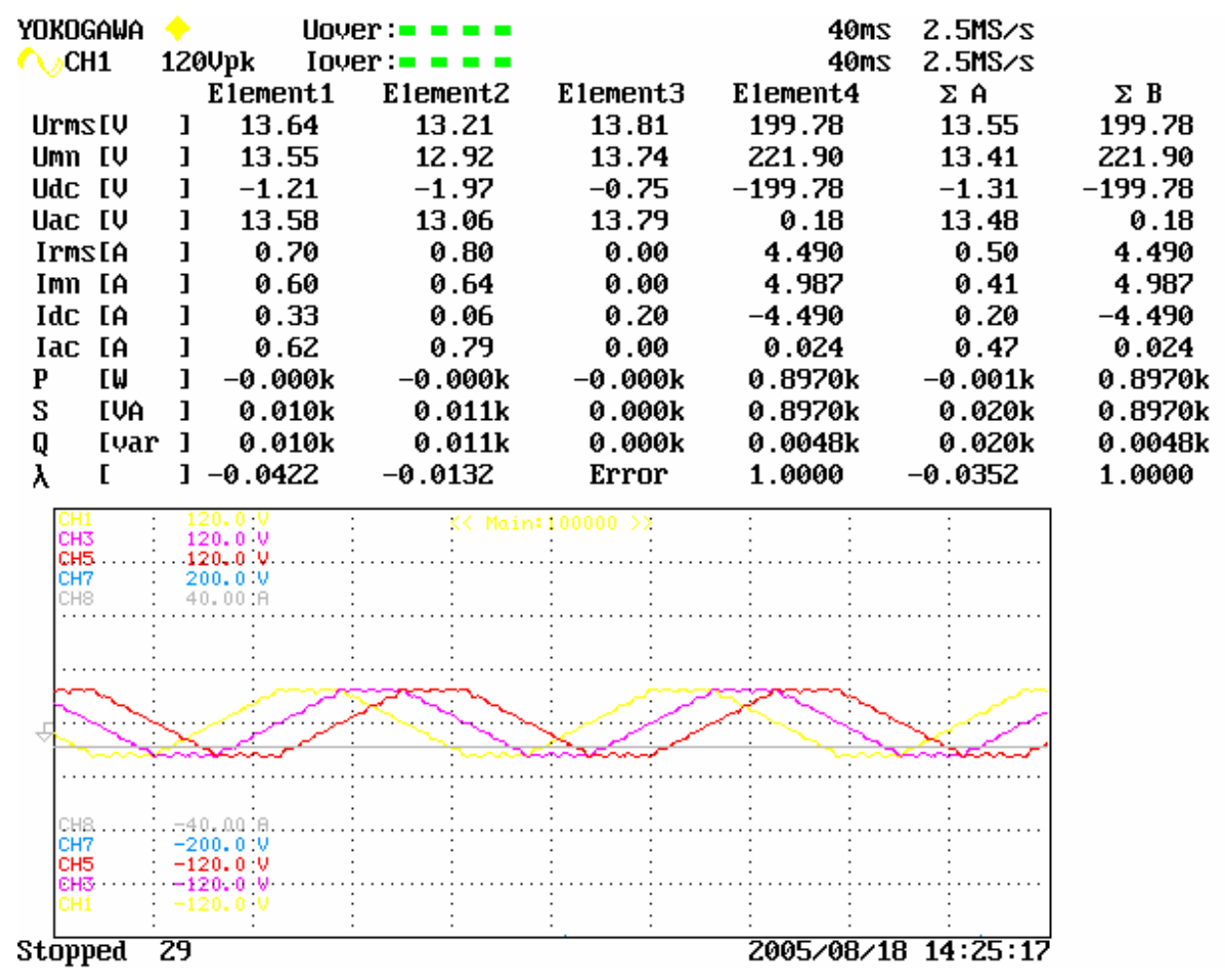

Fig. 15. Back-emf with field weakening 1000 rpm, 200 Vdc, and 4.49 Adc.

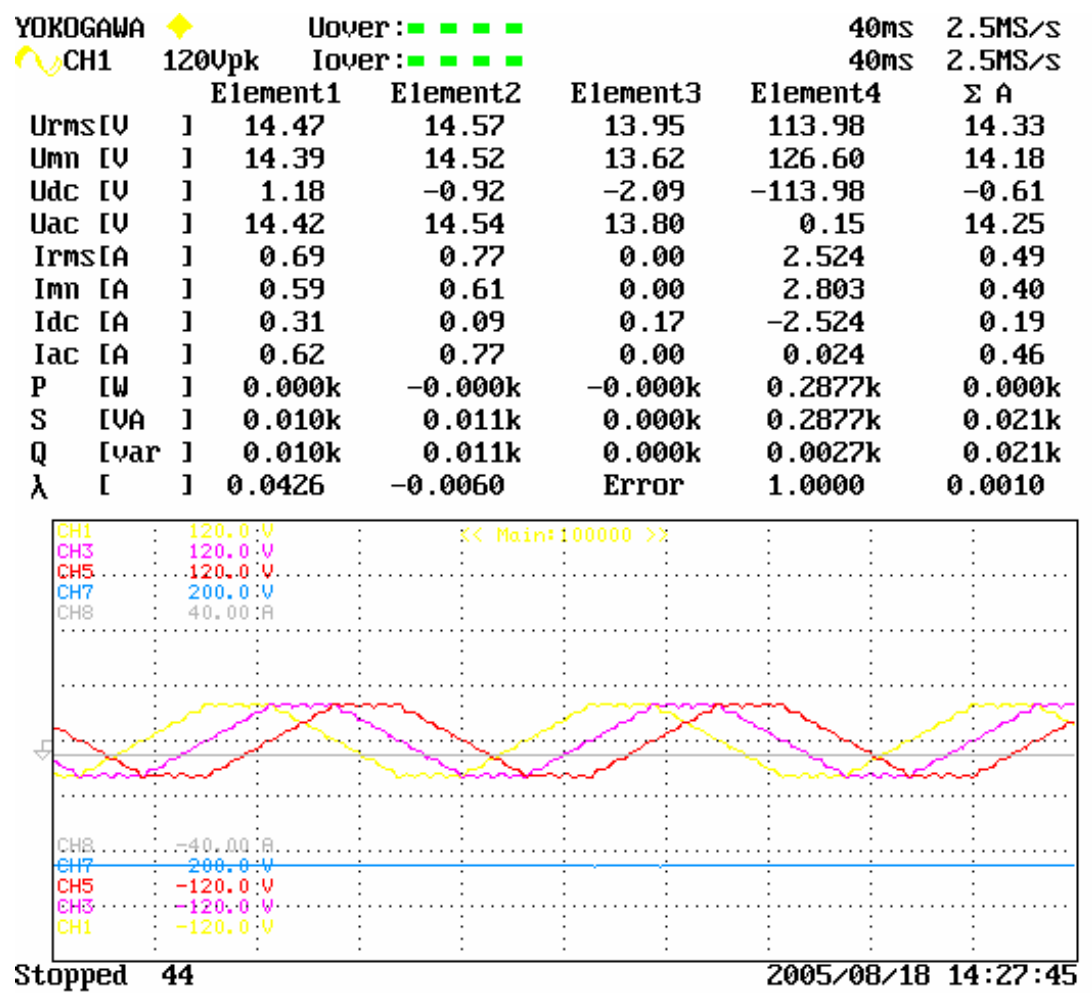

Fig. 16. Back-emf with field weakening 1000 rpm, 113.98 Vdc, and 2.5 Adc. 


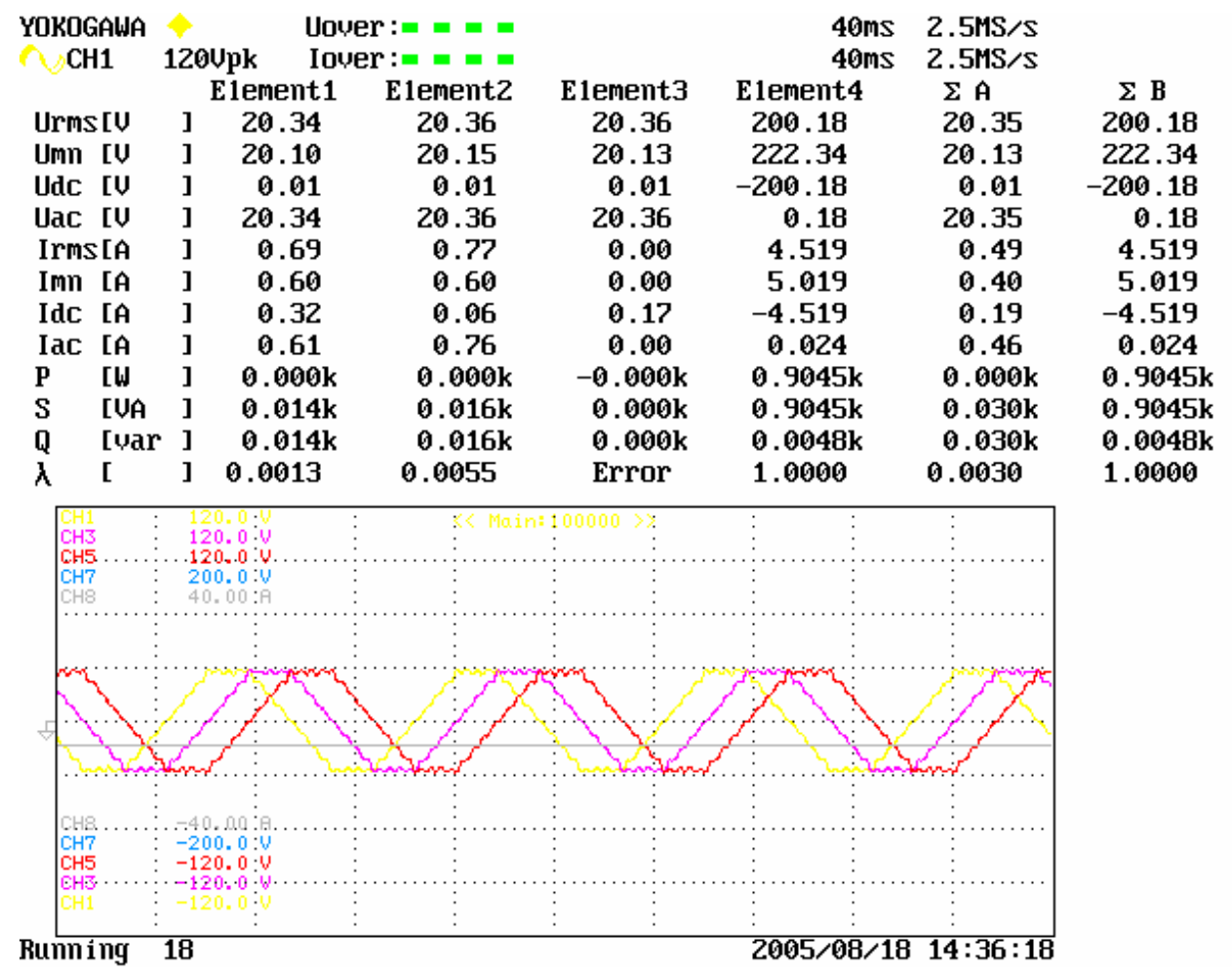

Fig. 17. Back-emf with field weakening 1500 rpm, 200 Vdc, and 4.51 Adc.

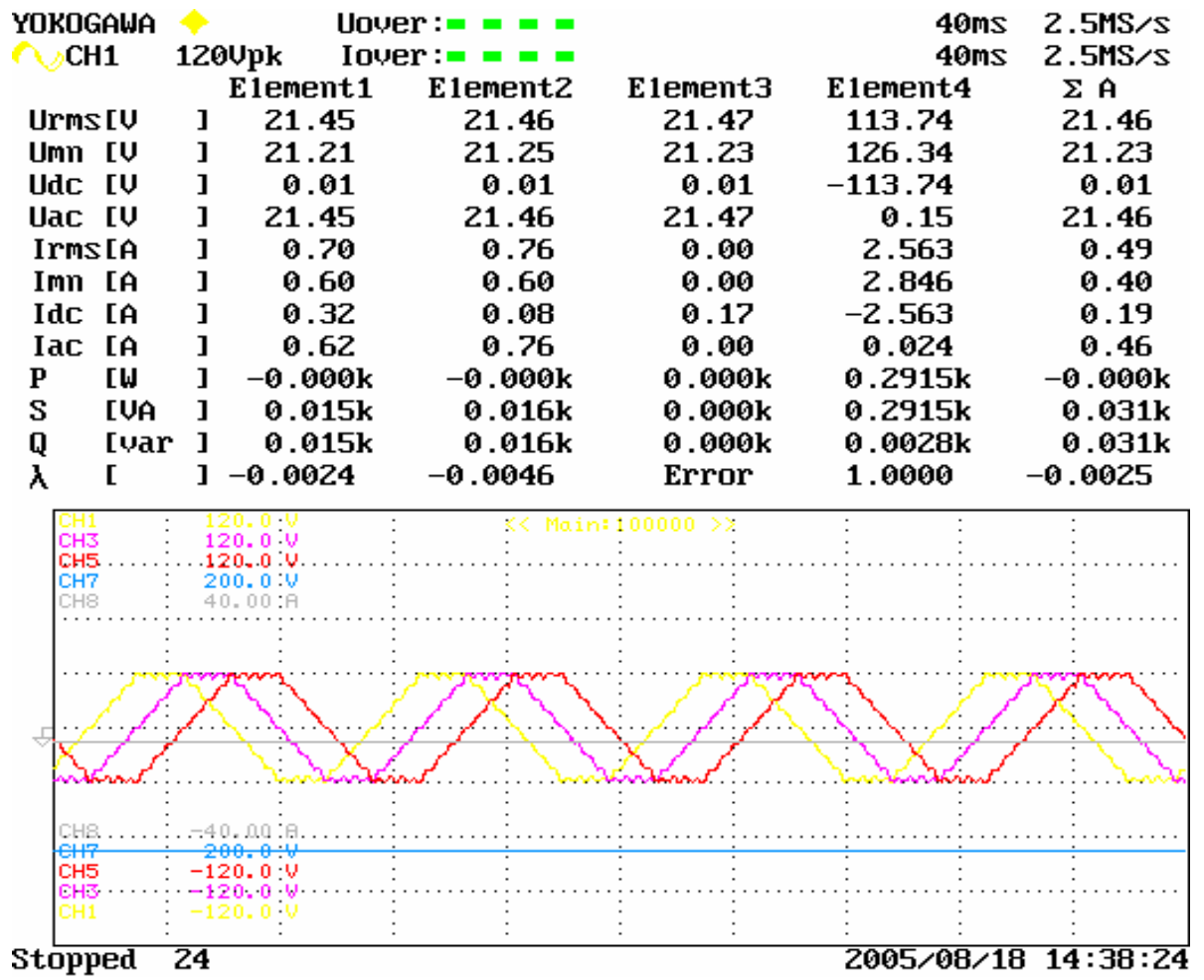

Fig. 18. Back-emf with field weakening 1500 rpm, 113.74 Vdc, and 2.56 Adc. 


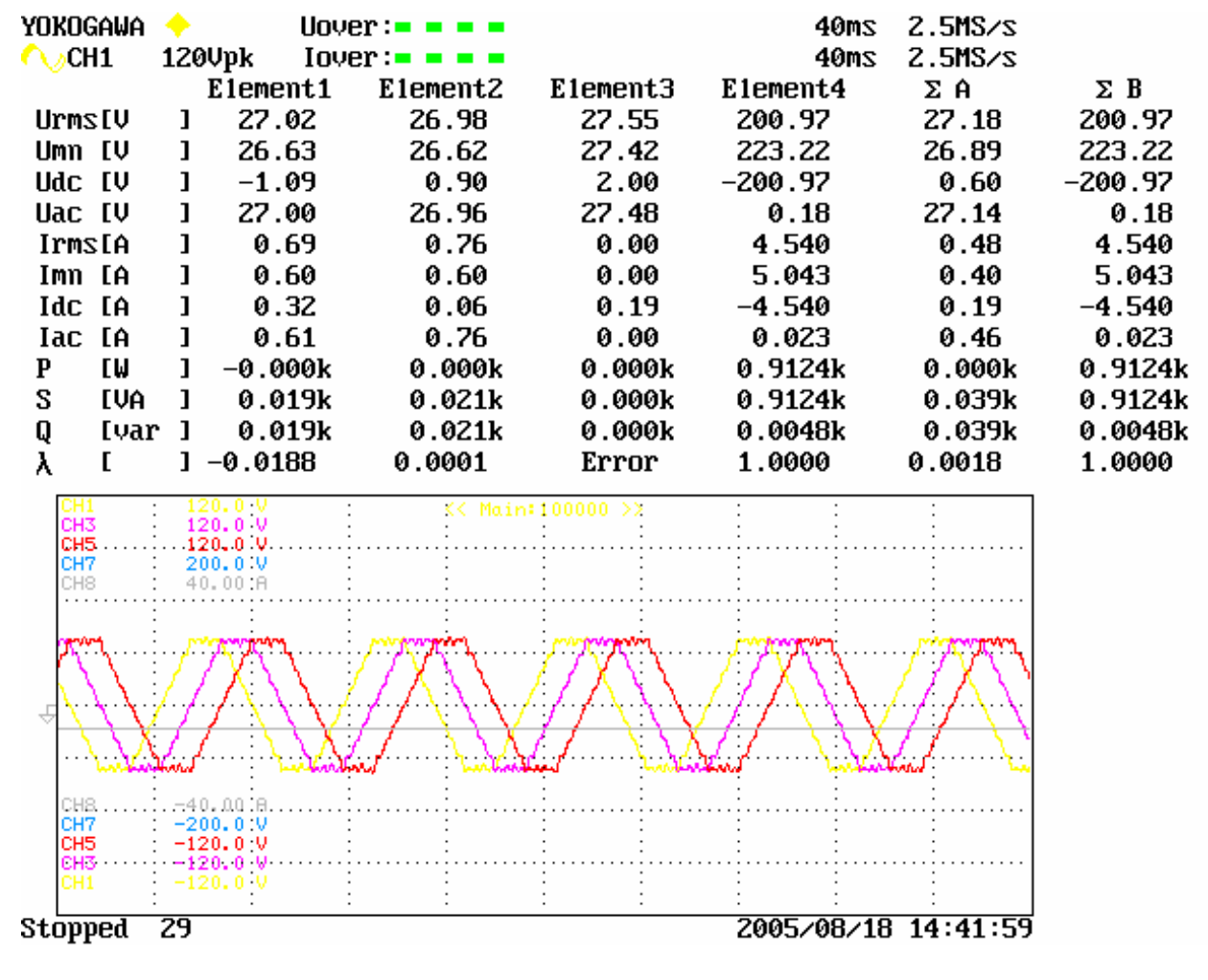

Fig. 19. Back-emf with field weakening 2000 rpm, 200 Vdc, and 4.54 Adc.

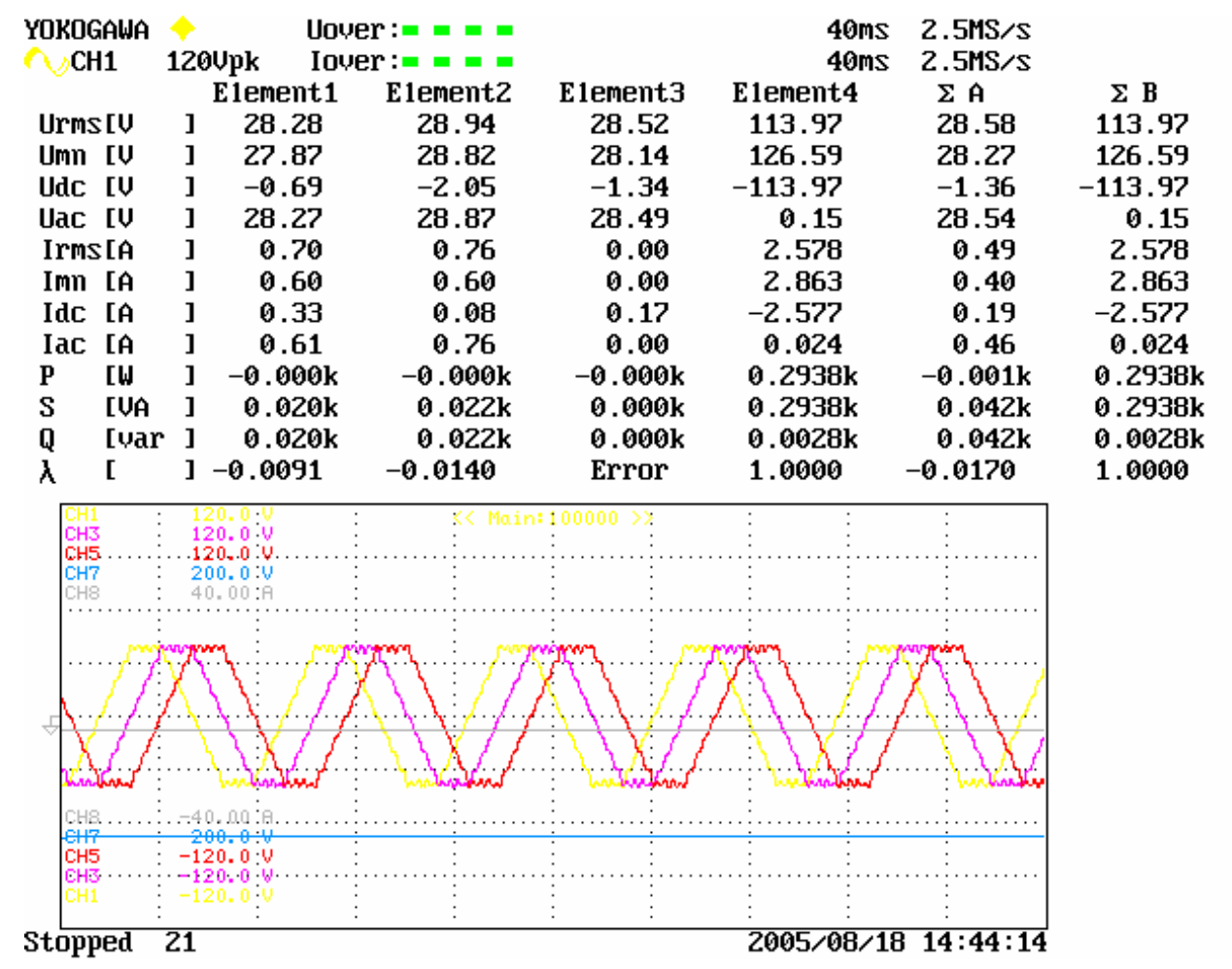

Fig. 20. Back-emf with field weakening 2000 rpm, 113.97 Vdc, and 2.57 Adc. 


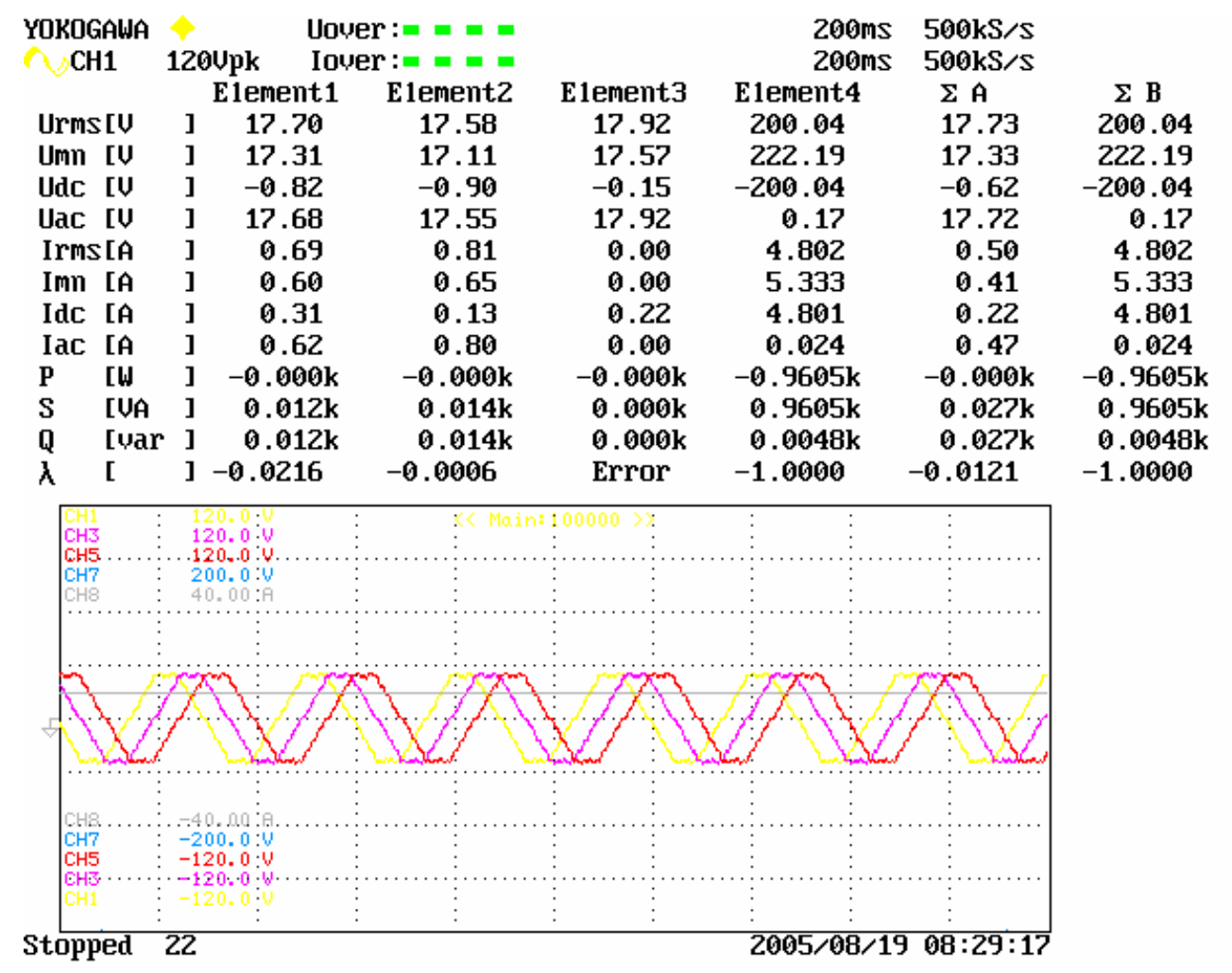

Fig. 21. Back-emf with field enhancement 500 rpm, 200 Vdc, and 4.8 Adc.

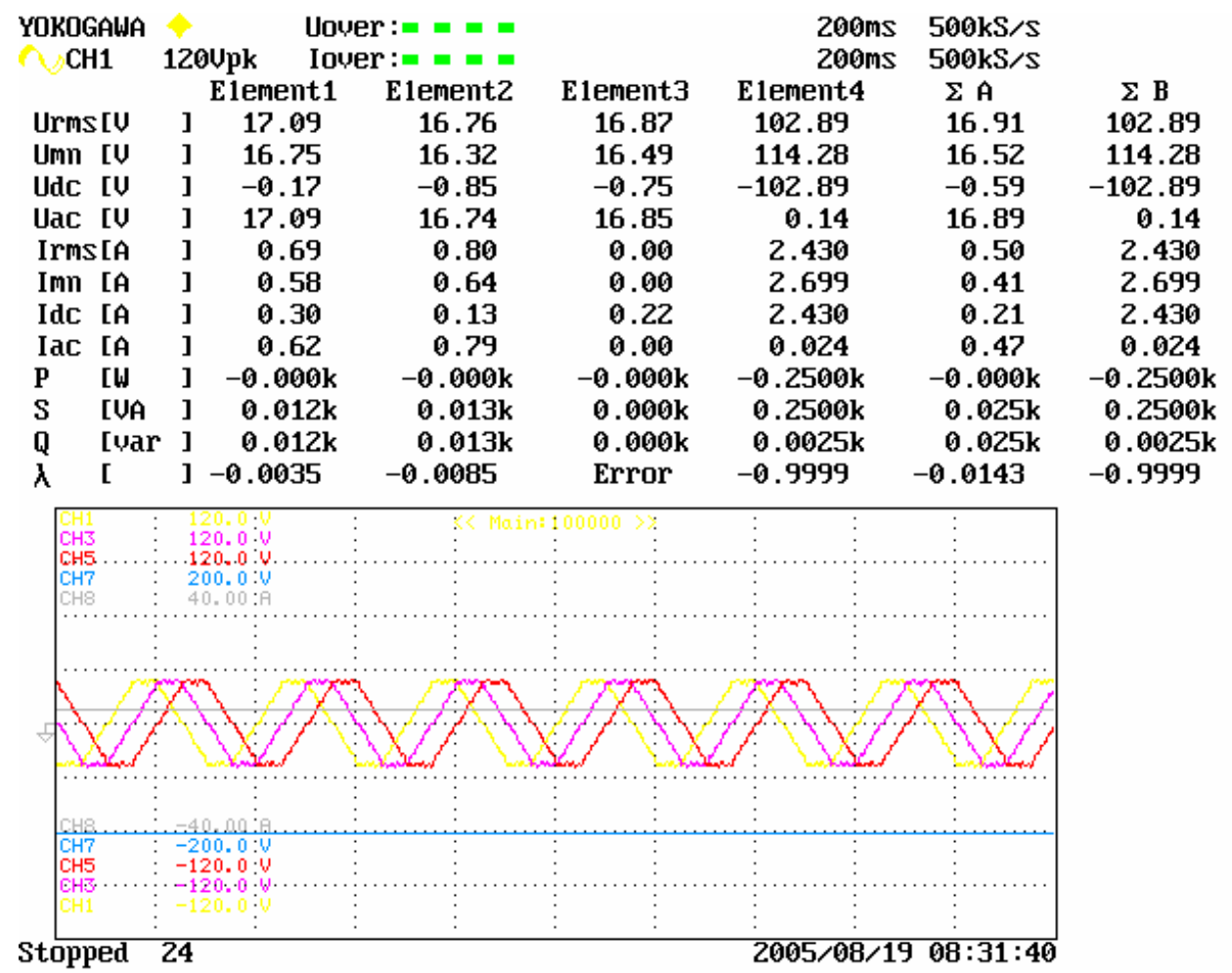

Fig. 22. Back-emf with field enhancement 500 rpm, 102 Vdc, and 2.4 Adc. 


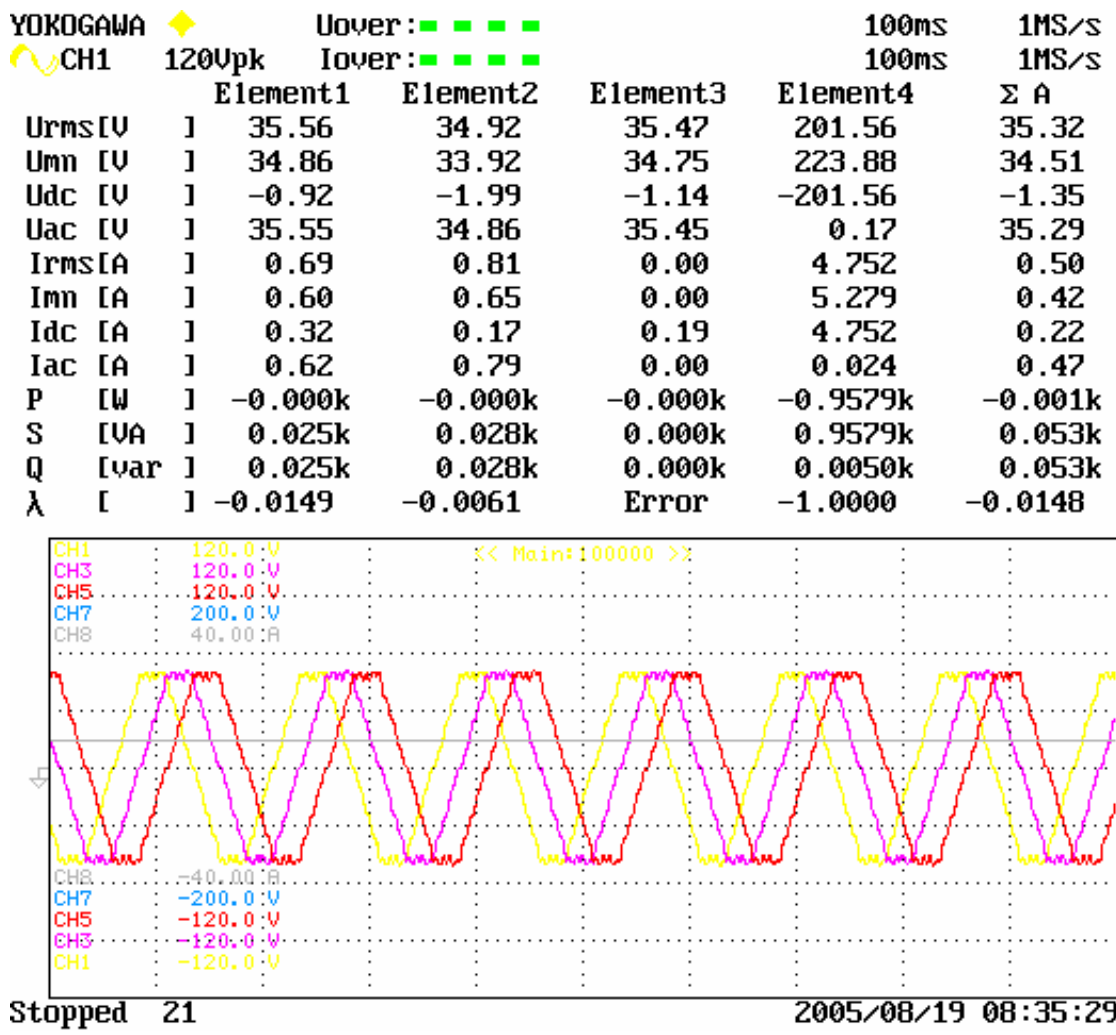

Fig. 23. Back-emf with field enhancement 1000 rpm, 200 Vdc, and 4.7 Adc.

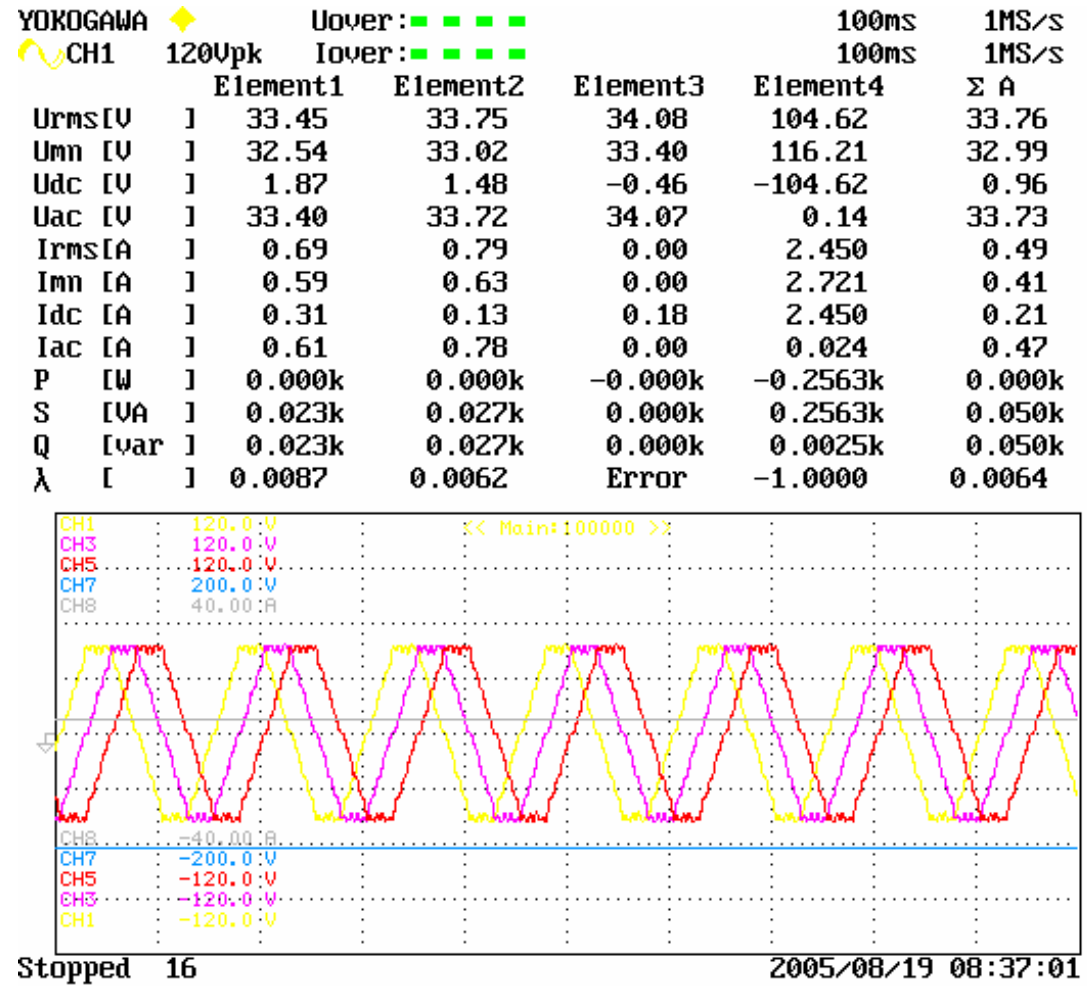

Fig. 24. Back-emf with field enhancement 1000 rpm, 104 Vdc, and 2.5 Adc. 


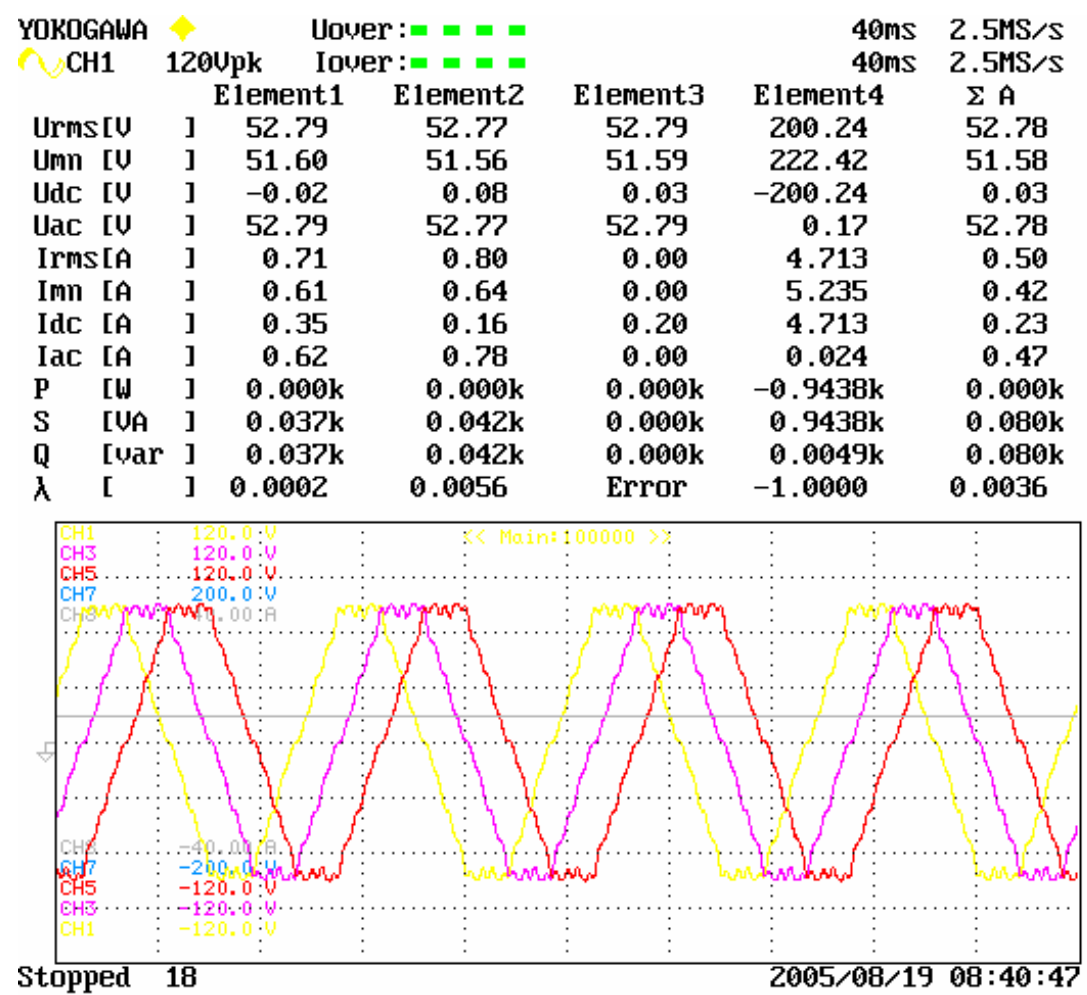

Fig. 25. Back-emf with field enhancement 1500 rpm, 200 Vdc, and 4.7 Adc.

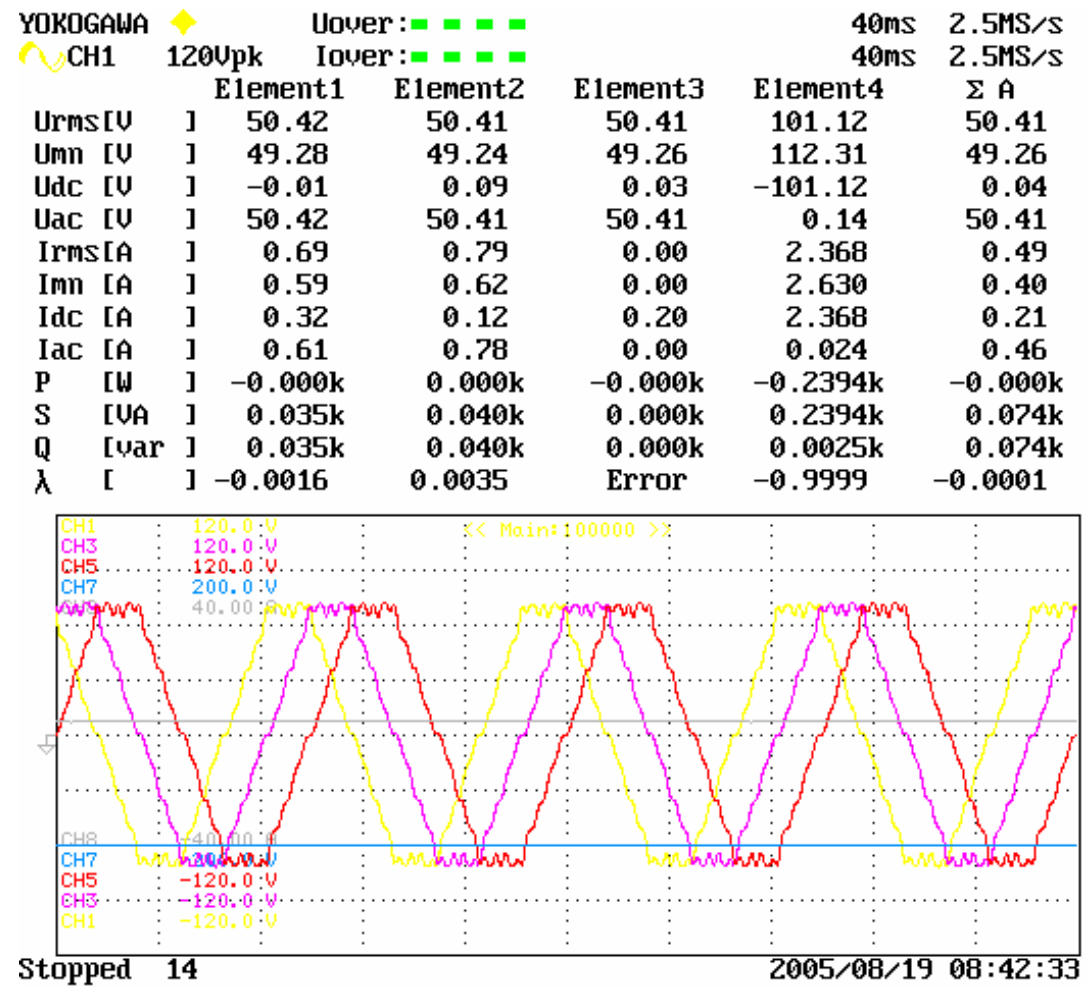

Fig. 26. Back-emf with field enhancement $1500 \mathrm{rpm}, 101 \mathrm{Vdc}$, and 2.3 Adc. 


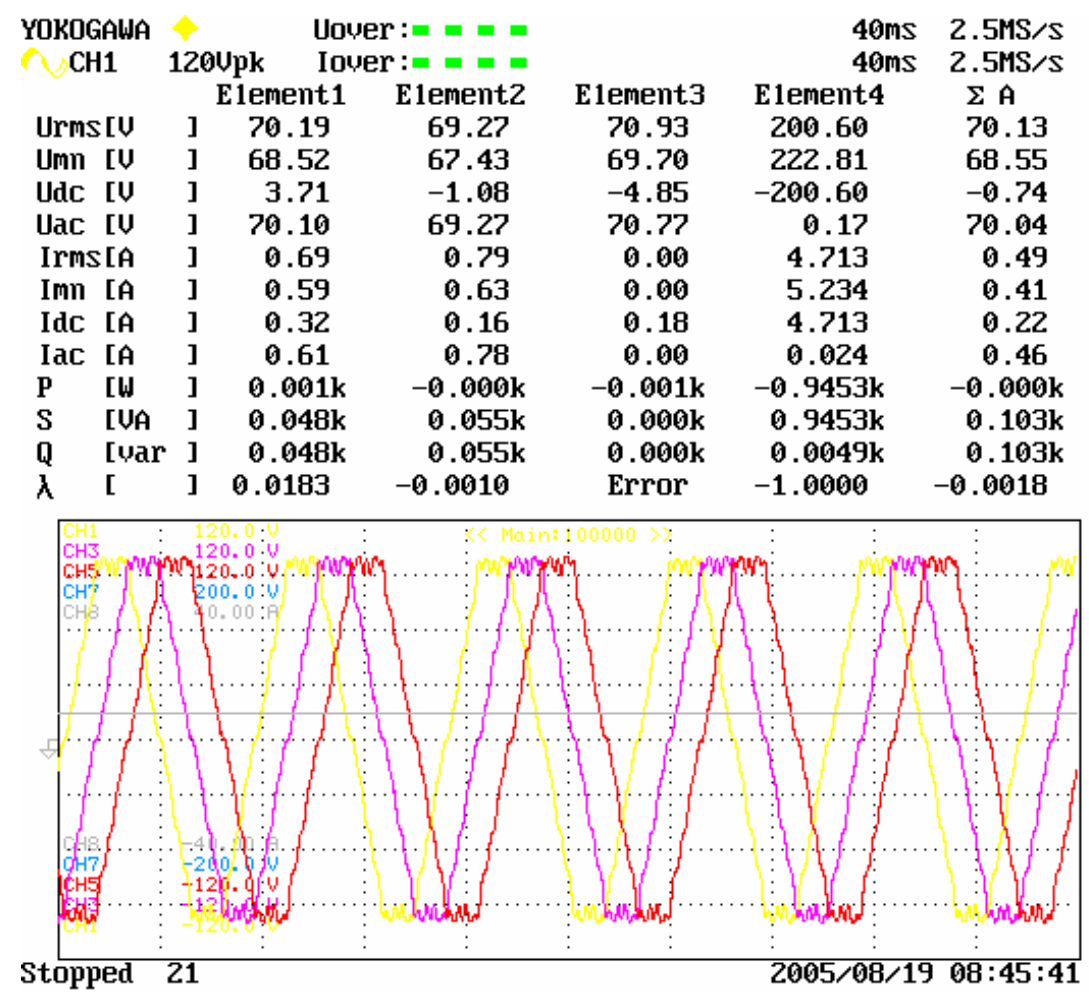

Fig. 27. Back-emf with field enhancement 2000 rpm, $200 \mathrm{Vdc}$, and 4.7 Adc.

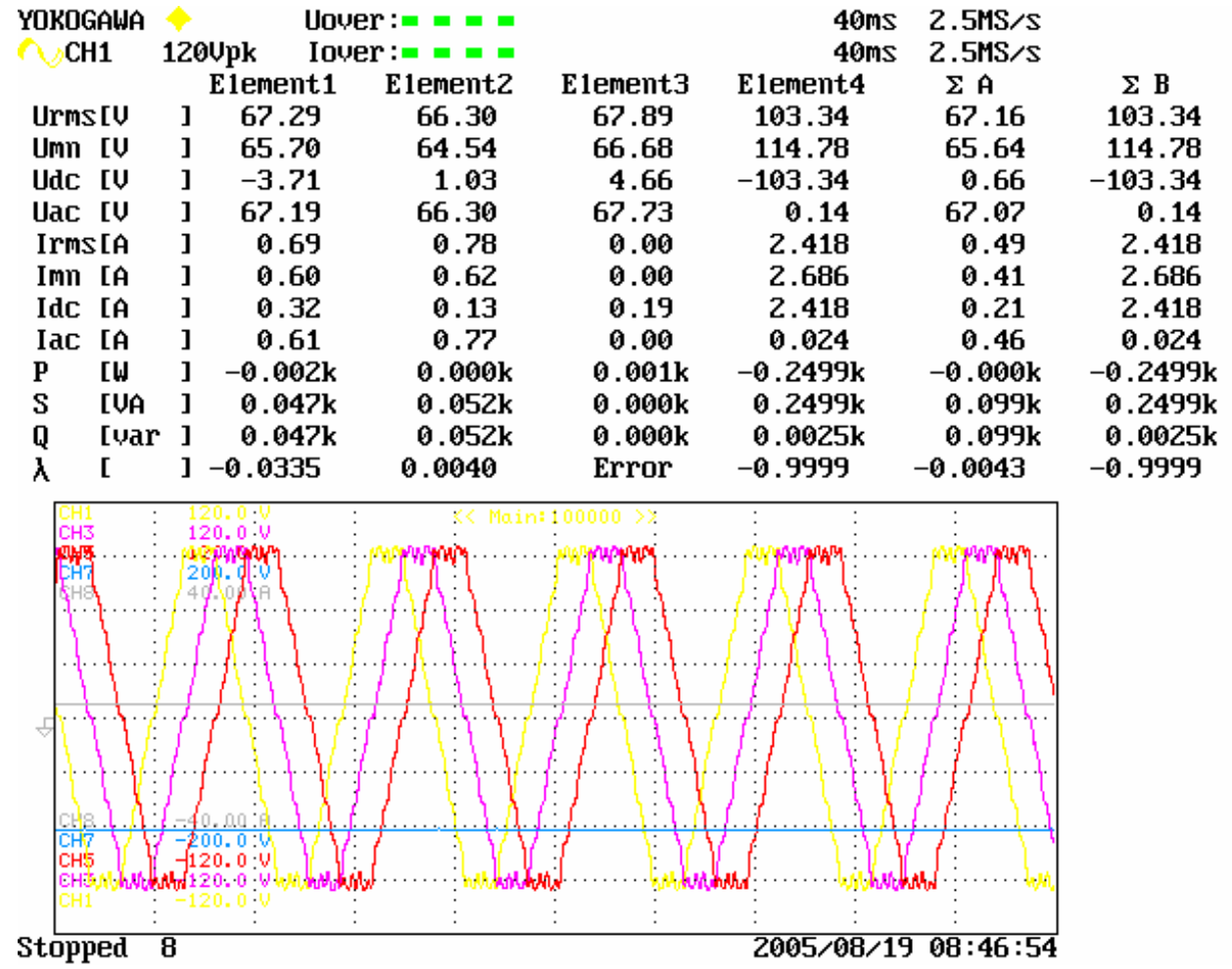

Fig. 28. Back-emf with field enhancement 2000 rpm, 103 Vdc, and 2.4 Adc. 
The mechanical losses on the rotor with 0.100 in.-thick magnets were recorded as follows in Tables 1 and 2.

Table 1. Mechanical losses on $0.100 \mathrm{in}$. magnet rotor with field weakening at $2000 \mathrm{rpm}$

$\begin{array}{cc}\text { No Excitation } & 0.1 \mathrm{Nm} \text { Torque } \\ 1.0 \mathrm{amp} \text { DC Current } & 0.3 \mathrm{Nm} \text { Torque } \\ 2.0 \mathrm{amp} \text { DC Current } & 0.7 \mathrm{Nm} \text { Torque } \\ 3.0 \mathrm{amp} \text { DC Current } & 1.1 \mathrm{Nm} \text { Torque } \\ 4.0 \mathrm{amp} \text { DC Current } & 1.4 \mathrm{Nm} \text { Torque } \\ 4.3 \mathrm{amp} \mathrm{DC} \text { Current @ } 200 \text { Volts DC } & 1.5 \mathrm{Nm} \text { Torque } \\ 4.5 \mathrm{amp} \text { DC Current @ 200 Volts DC } & 1.6 \mathrm{Nm} \text { Torque } \\ 4.0 \mathrm{amp} \text { DC Current } & 1.4 \mathrm{Nm} \text { Torque } \\ 3.0 \mathrm{amp} \text { DC Current } & 1.1 \mathrm{Nm} \text { Torque } \\ 2.0 \mathrm{amp} \text { DC Current } & 0.6 \mathrm{Nm} \text { Torque } \\ 1.0 \mathrm{amp} \text { DC Current } & 0.2 \mathrm{Nm} \text { Torque } \\ \text { No Excitation } & 0.1 \mathrm{Nm} \text { Torque }\end{array}$

Table 2. Mechanical losses on $0.100 \mathrm{in}$. magnet rotor with field enhancement at $2000 \mathrm{rpm}$

$\begin{array}{cc}\text { No Excitation } & 0.2 \mathrm{Nm} \text { Torque } \\ 1.0 \mathrm{amp} \text { DC Current } & 0.4 \mathrm{Nm} \text { Torque } \\ 2.0 \mathrm{amp} \text { DC Current } & 0.7 \mathrm{Nm} \text { Torque } \\ 3.0 \mathrm{amp} \text { DC Current } & 1.2 \mathrm{Nm} \text { Torque } \\ 4.0 \mathrm{amp} \text { DC Current } & 1.6 \mathrm{Nm} \text { Torque } \\ 4.5 \text { amp DC Current @ } 200 \text { Volts DC } & 1.8 \mathrm{Nm} \text { Torque } \\ 4.0 \mathrm{amp} \text { DC Current } & 1.6 \mathrm{Nm} \text { Torque } \\ 3.0 \mathrm{amp} \text { DC Current } & 1.2 \mathrm{Nm} \text { Torque } \\ 2.0 \mathrm{amp} \text { DC Current } & 0.6 \mathrm{Nm} \text { Torque } \\ 1.0 \mathrm{amp} \text { DC Current } & 0.4 \mathrm{Nm} \text { Torque } \\ \text { No Excitation } & 0.2 \mathrm{Nm} \text { Torque }\end{array}$




\section{PERFORMANCE DATA OF THE 0.240 INCH MAGNET ROTOR}

The RIPM-BFE motor with the 0.240 in. magnet rotor was instrumented to record back-emf of each phase of the motor. Each phase was read from phase to neutral. The motor was coupled to the dynamometer and driven at rpm set-points of 500, 1000, 1500, and 2000. The back-emf was measured on each phase of the motor and the results were recorded. These measurements will be used for checking demagnetization in the future. Back-emf was also recorded at each rpm setpoint while both "enhancing" and "weakening” the magnetic field. The test parameters for each enhancement and weakening measurement were: 500, 1000, 1500, and $2000 \mathrm{rpm}$; 1-5.0 Adc in 1.0 Adc increments; or a maximum of $200 \mathrm{Vdc}$. Additionally, the mechanical losses were recorded (in $\mathrm{Nm}$ ) at 1.0 Adc increments up to 5.0 Adc or a maximum of 200 Vdc. The mechanical losses were recorded at $2000 \mathrm{rpm}$ without field enhancement or weakening. Data recorded is presented in Figs. 29-72.

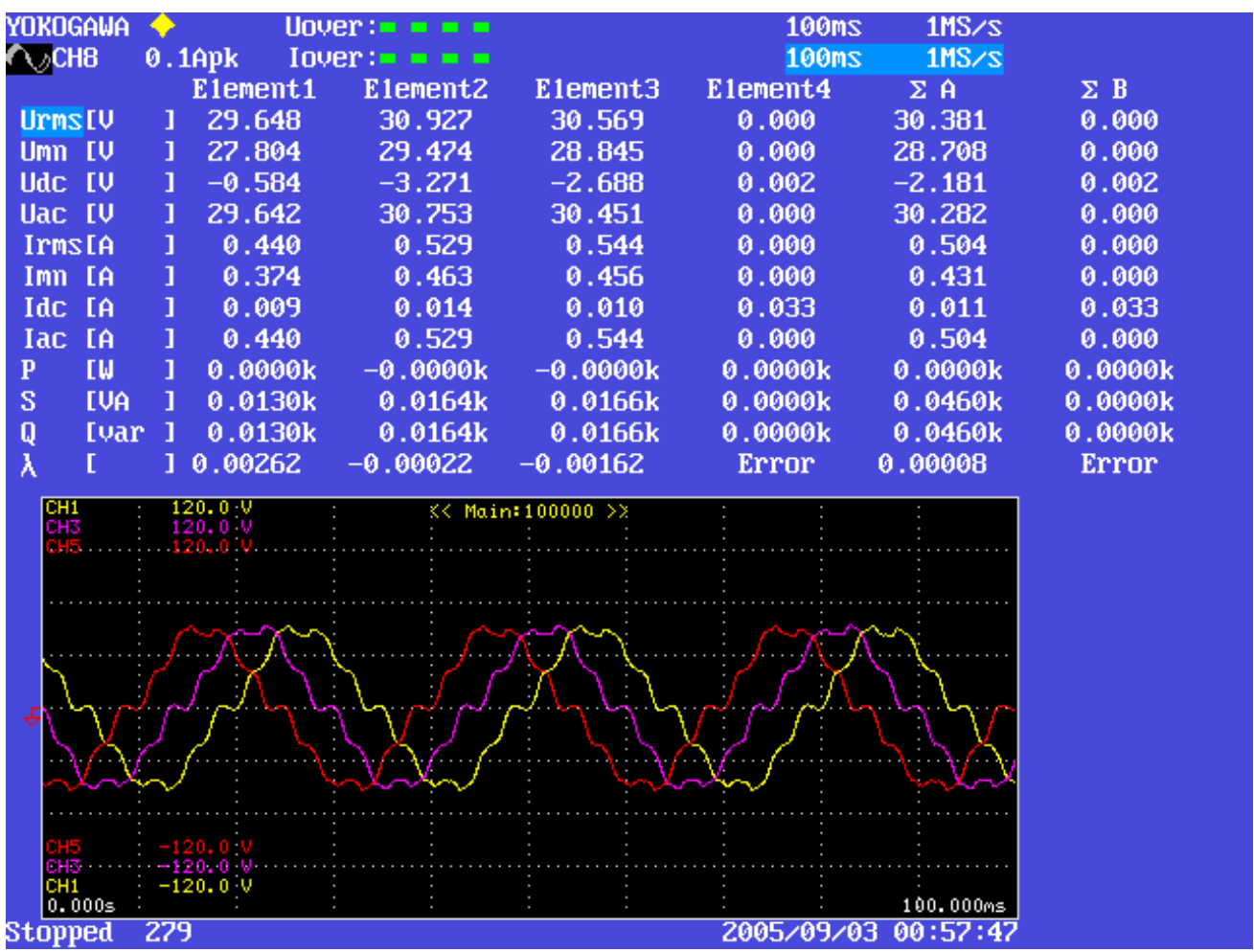

Fig. 29. $0.240 \mathrm{in}$. thick magnet rotor back-emf at $500 \mathrm{rpm}$ without field weakening/enhancement. 


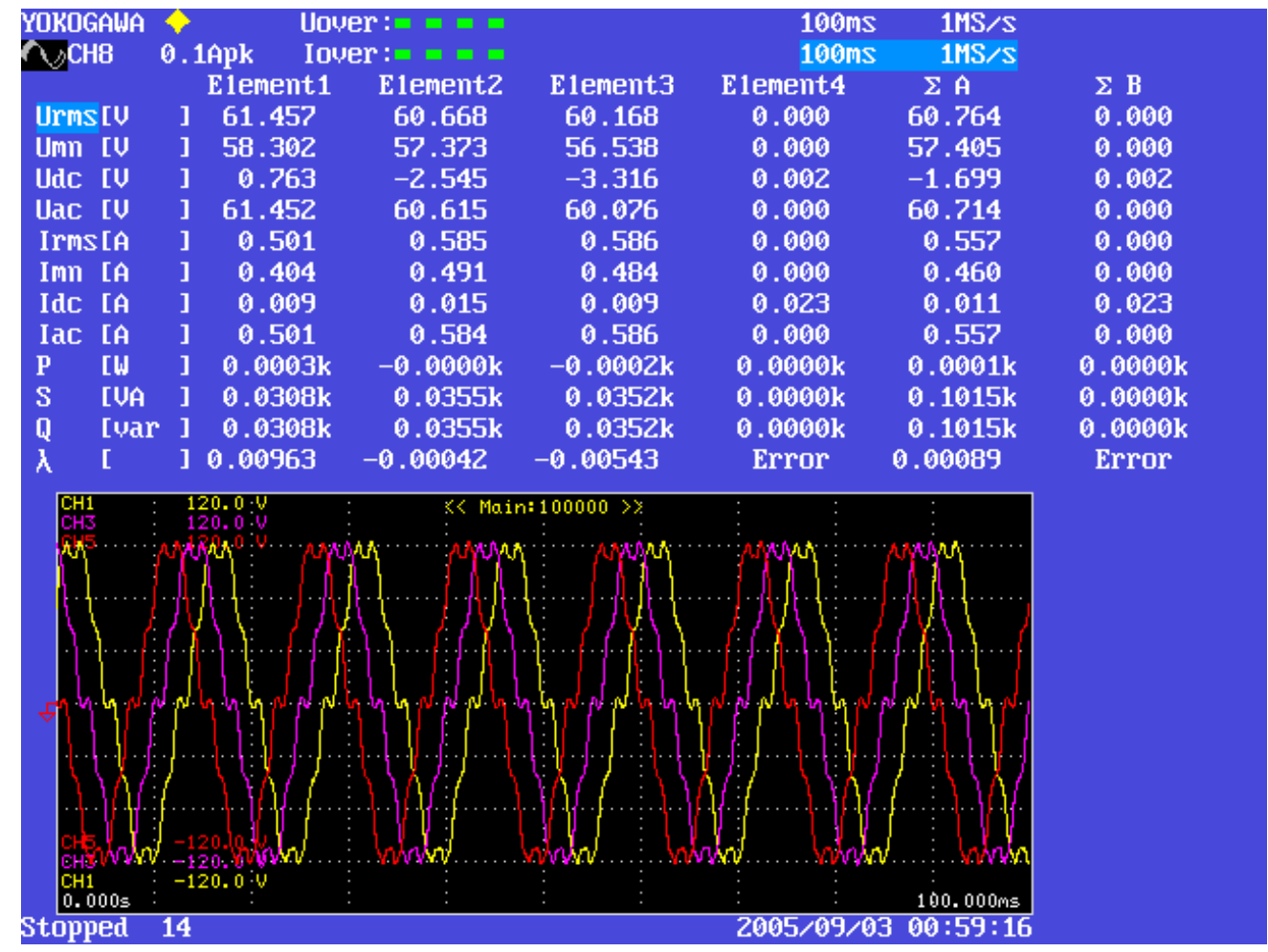

Fig. 30. 0.240 in. thick magnet rotor back-emf at $1000 \mathrm{rpm}$ without field weakening/enhancement.

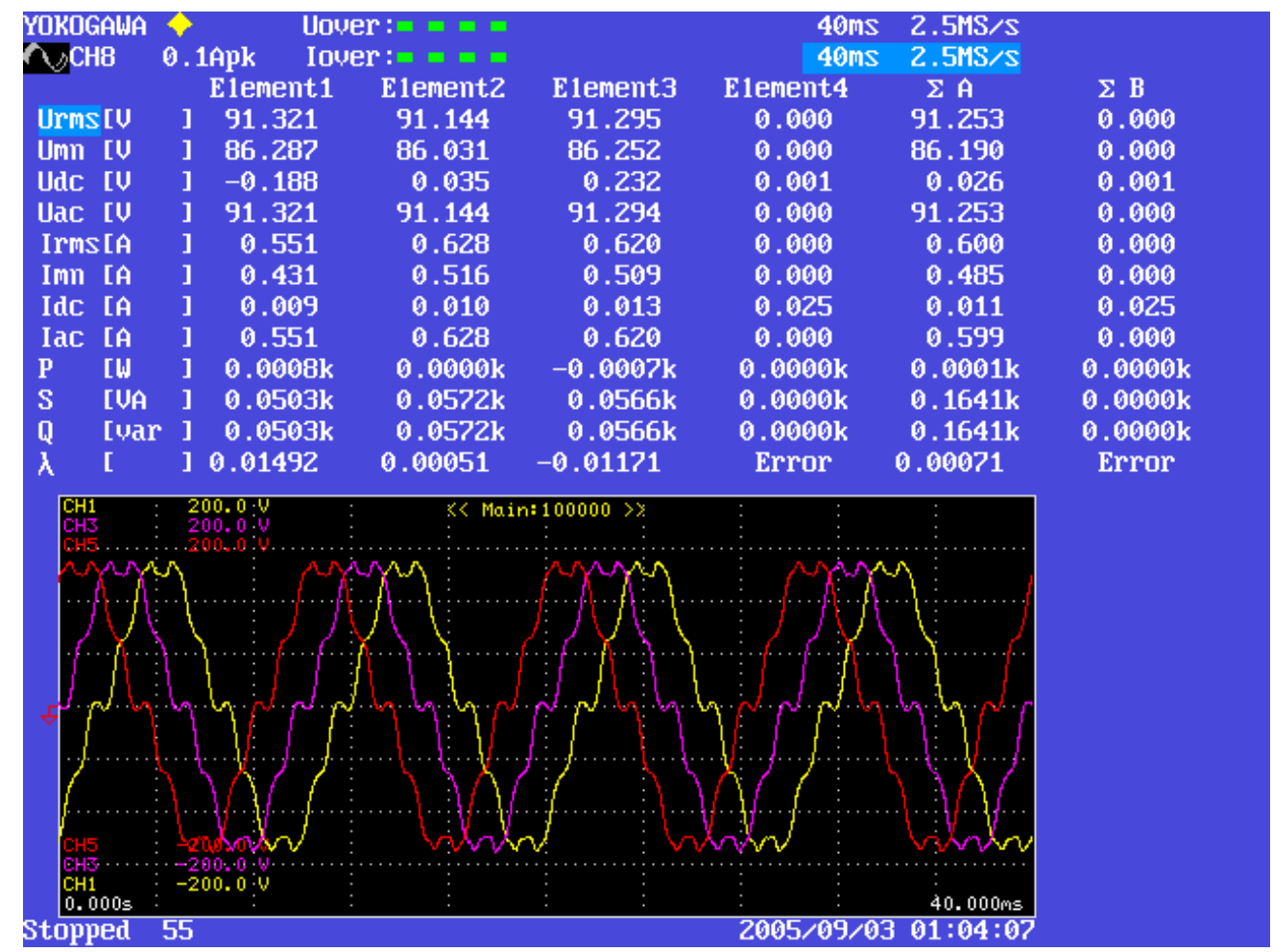

Fig. 31. 0.240 in. thick magnet rotor back-emf at $1500 \mathrm{rpm}$ without field weakening/enhancement. 


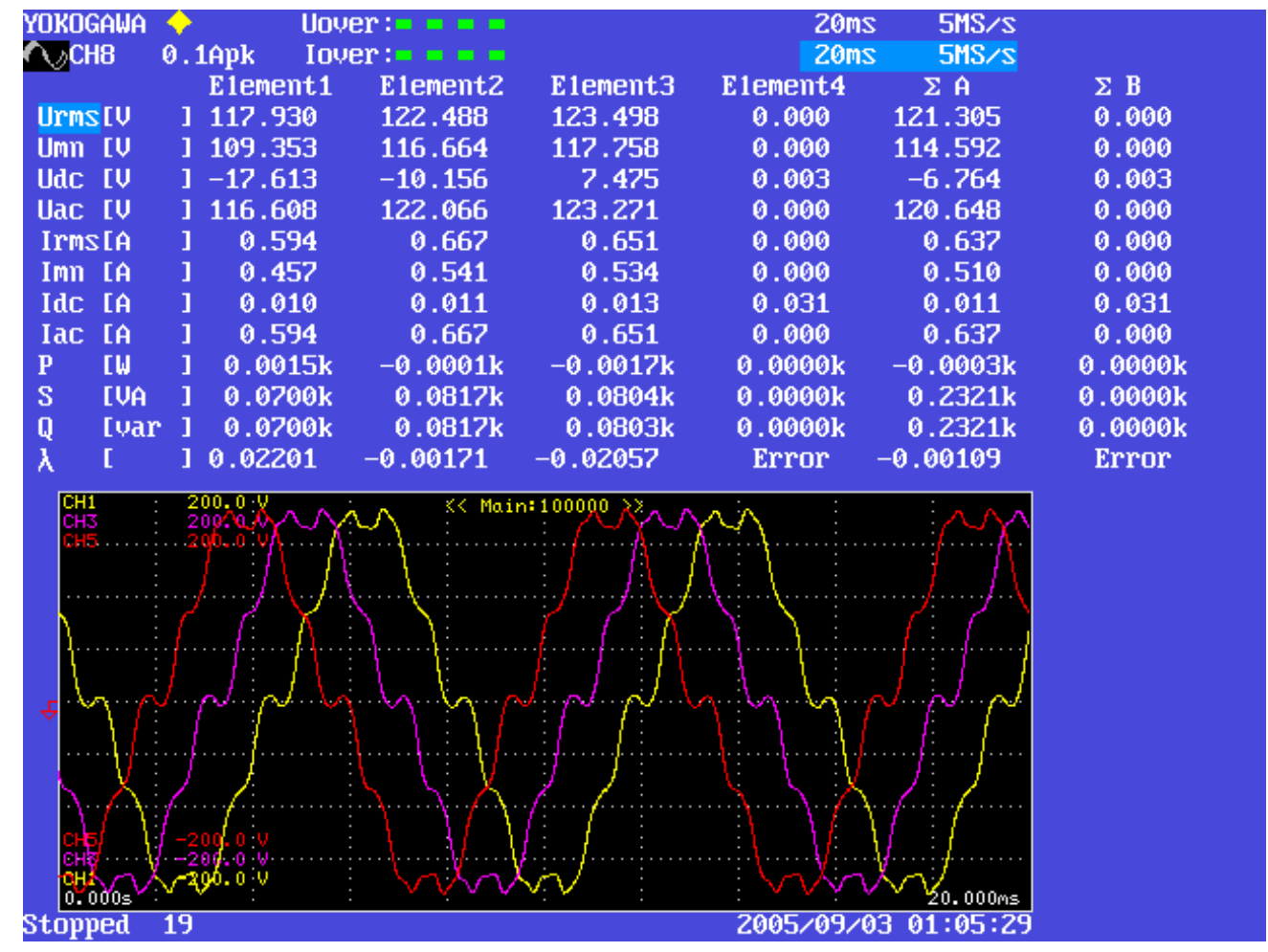

Fig. 32. 0.240 in. thick magnet rotor back-emf at $2000 \mathrm{rpm}$ without field weakening/enhancement.

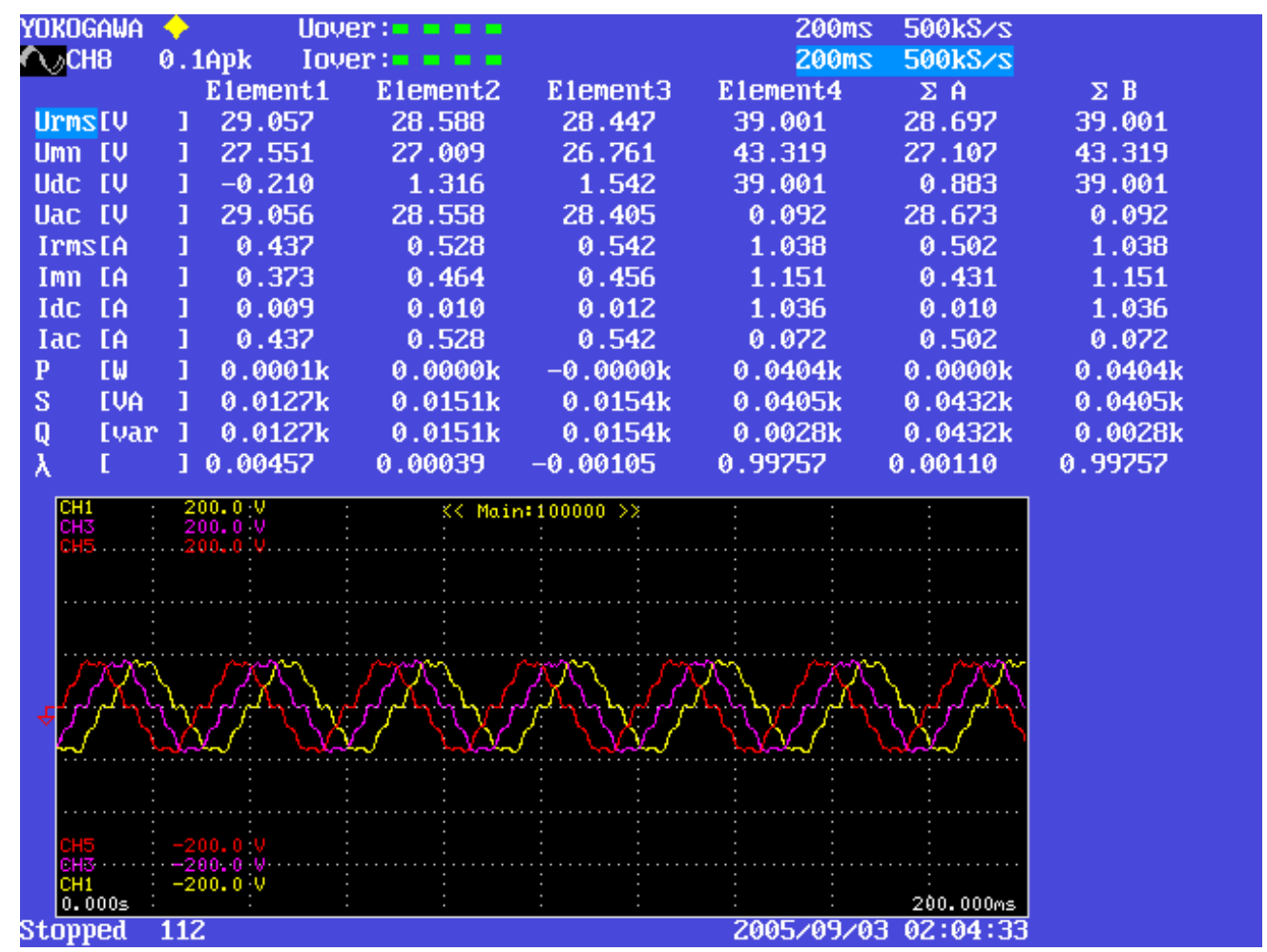

Fig. 33. 0.240 in. thick magnet rotor back-emf at $500 \mathrm{rpm}$ with field weakening at 1 Adc. 


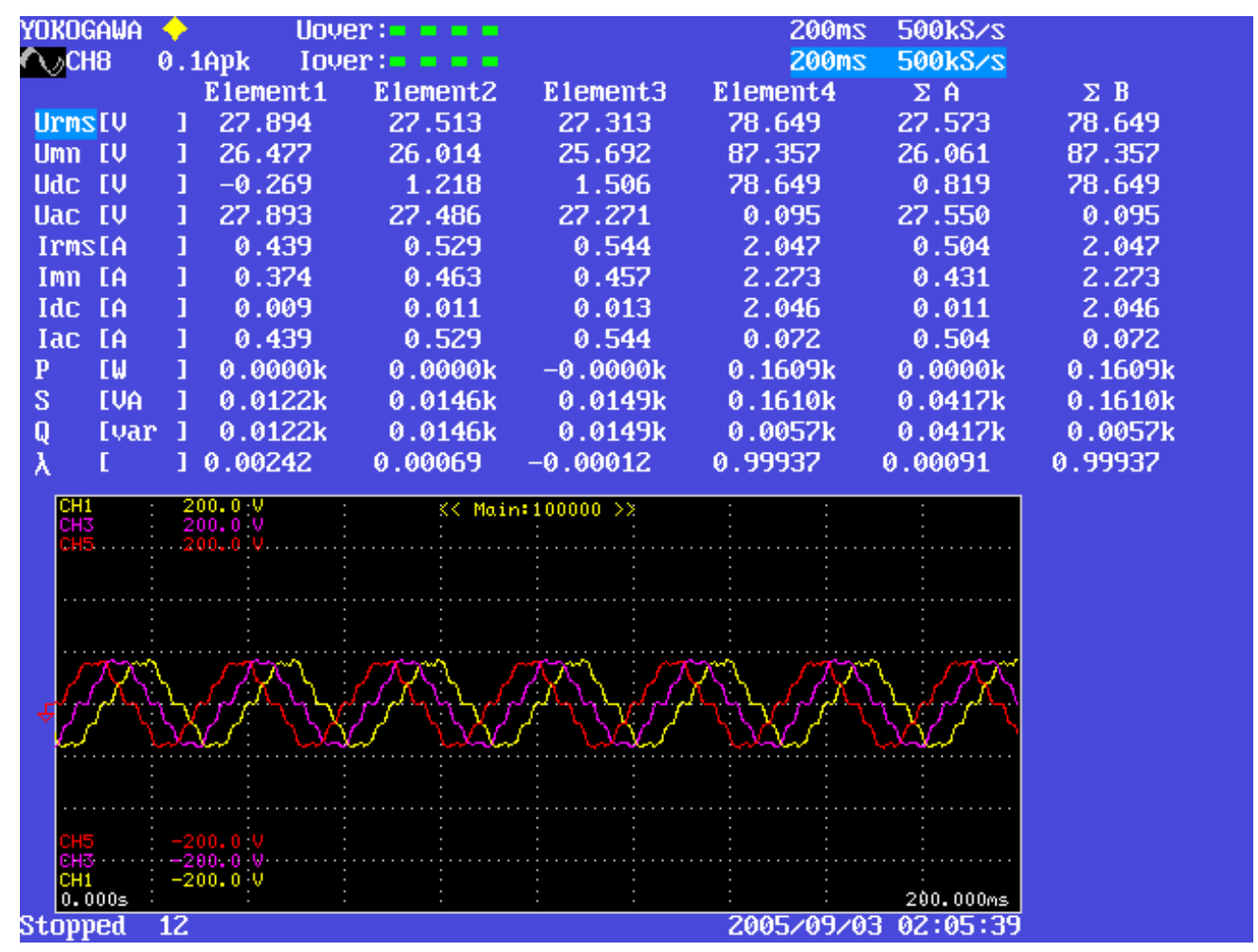

Fig. 34.0 .240 in. thick magnet rotor back-emf at $500 \mathrm{rpm}$ with field weakening at 2 Adc.

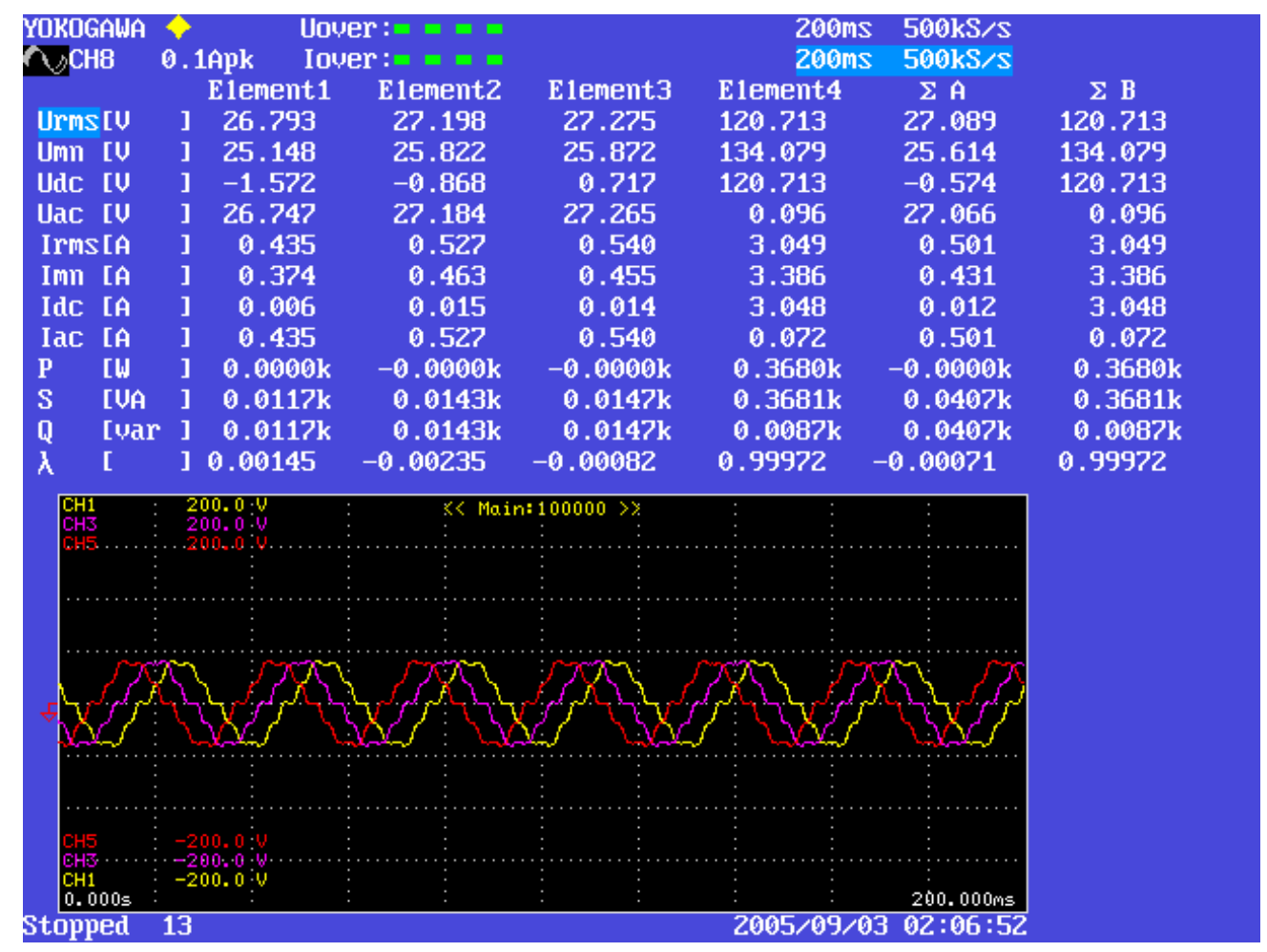

Fig. 35. 0.240 in. thick magnet rotor back-emf at $500 \mathrm{rpm}$ with field weakening at 3 Adc. 


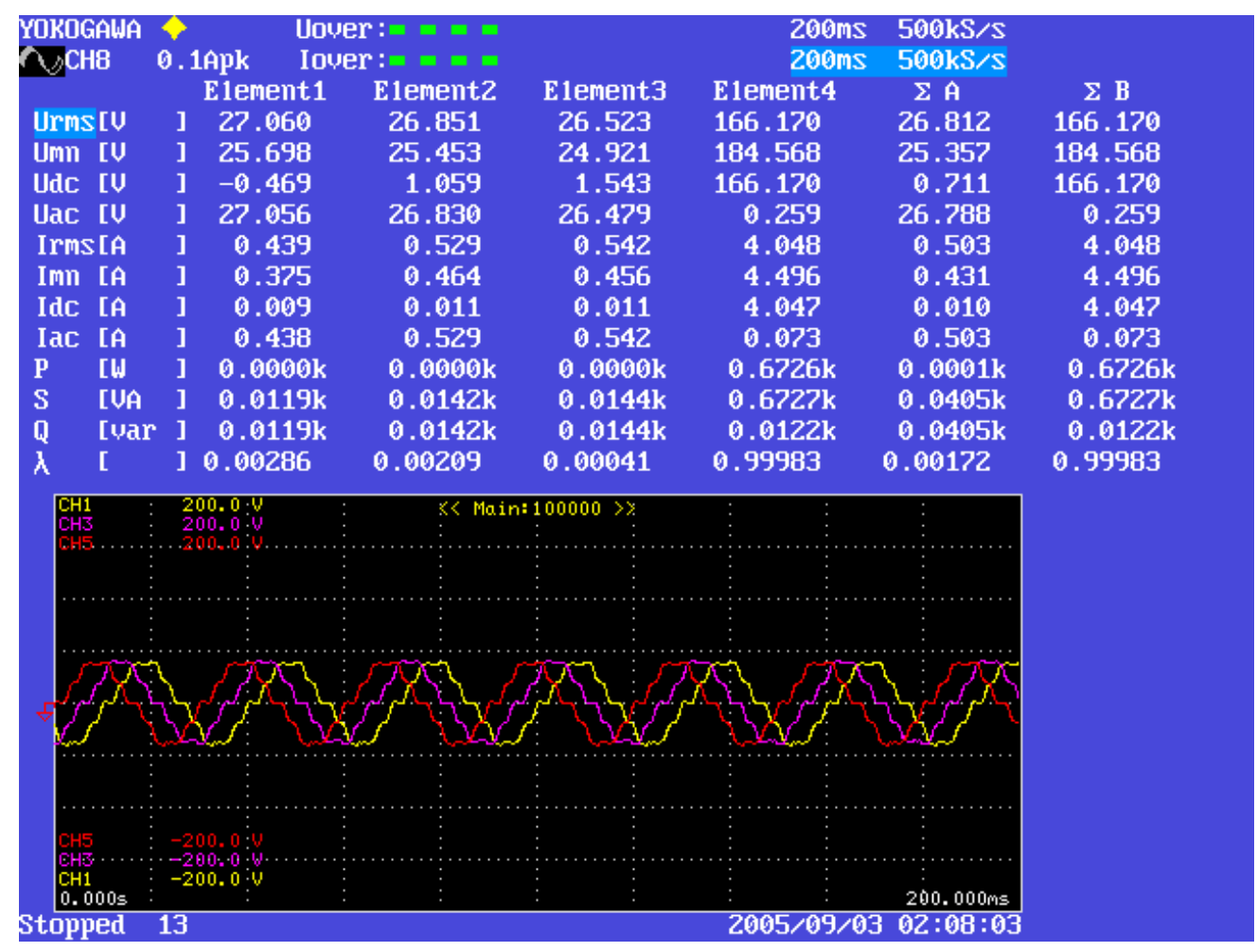

Fig. $36.0 .240 \mathrm{in}$. thick magnet rotor back-emf at $500 \mathrm{rpm}$ with field weakening at 4 Adc.

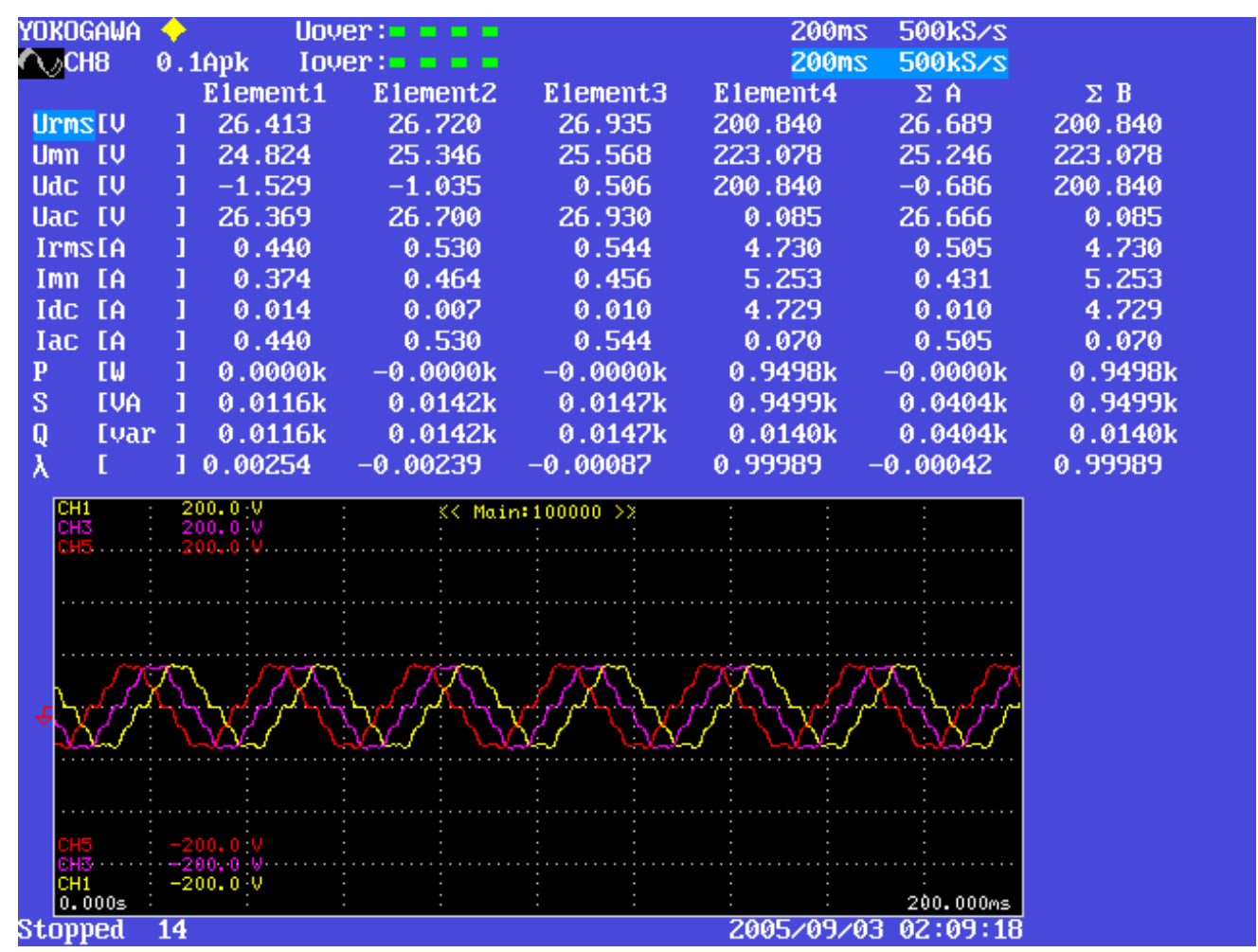

Fig. 37.0 .240 in. thick magnet rotor back-emf at $500 \mathrm{rpm}$ with field weakening at 5 Adc. 


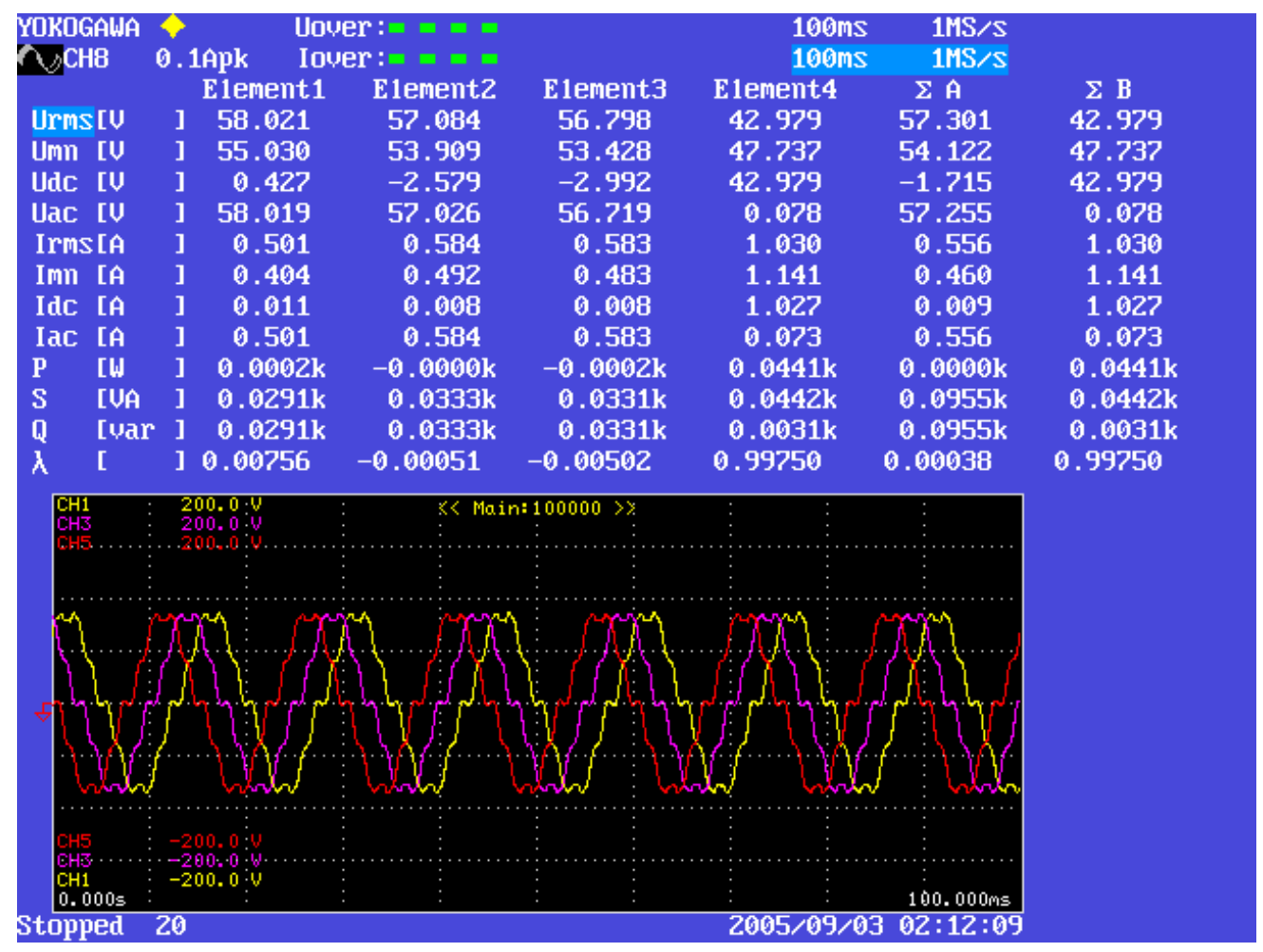

Fig. 38. 0.240 in. thick magnet rotor back-emf at $1000 \mathrm{rpm}$ with field weakening at 1 Adc.

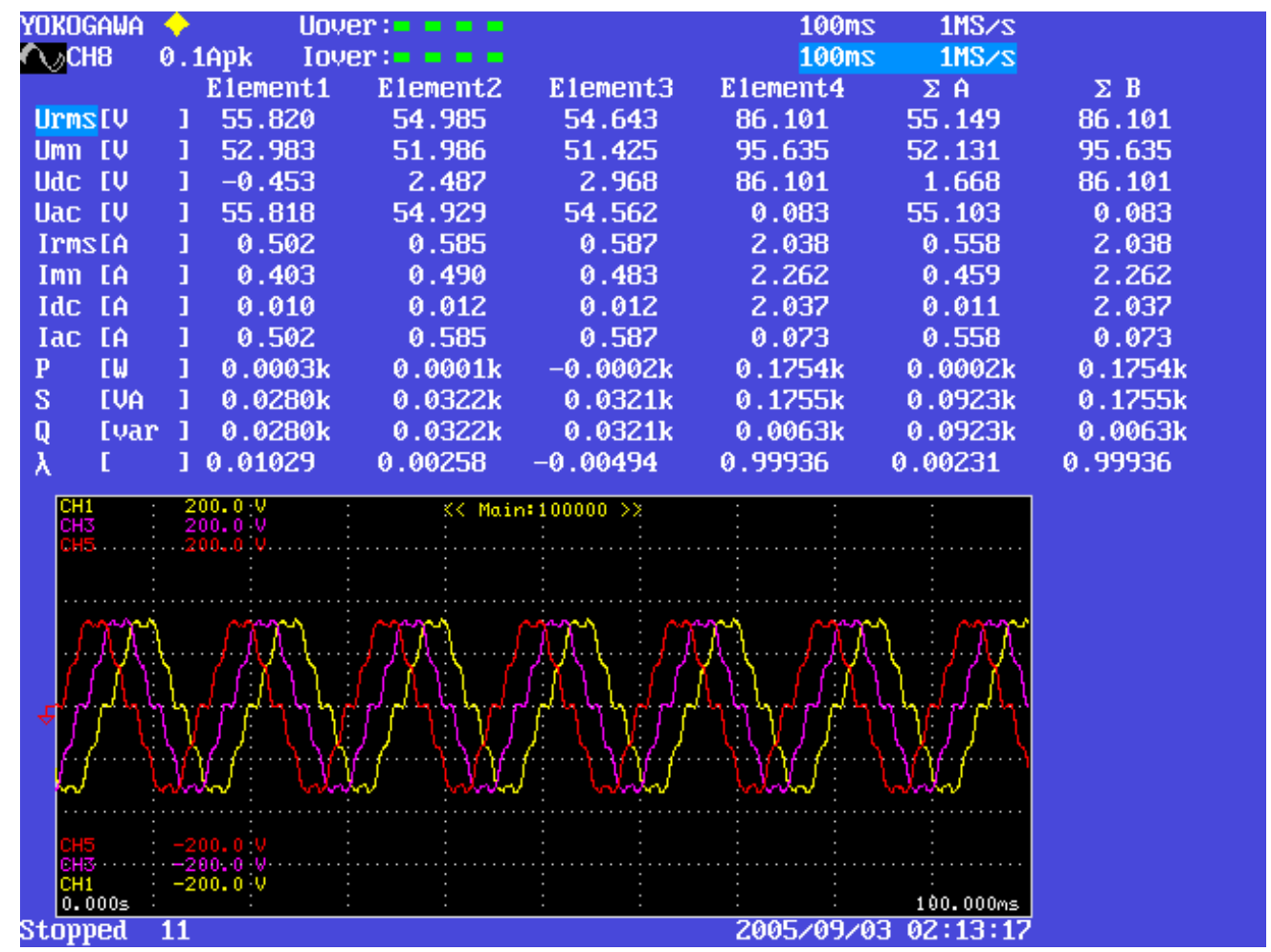

Fig. 39. $0.240 \mathrm{in}$. thick magnet rotor back-emf at $1000 \mathrm{rpm}$ with field weakening at 2 Adc. 


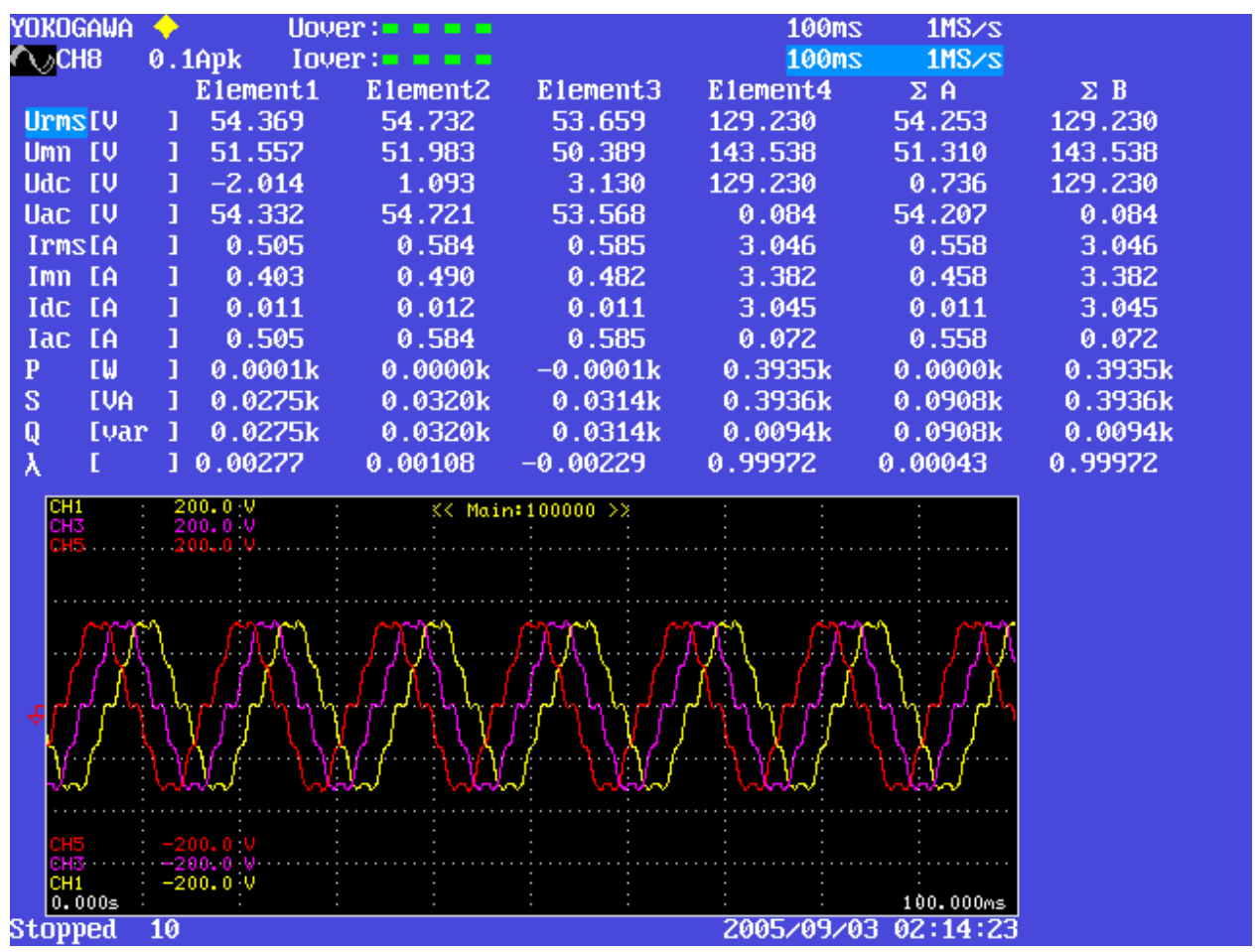

Fig. 40. $0.240 \mathrm{in}$. thick magnet rotor back-emf at $1000 \mathrm{rpm}$ with field weakening at 3 Adc.

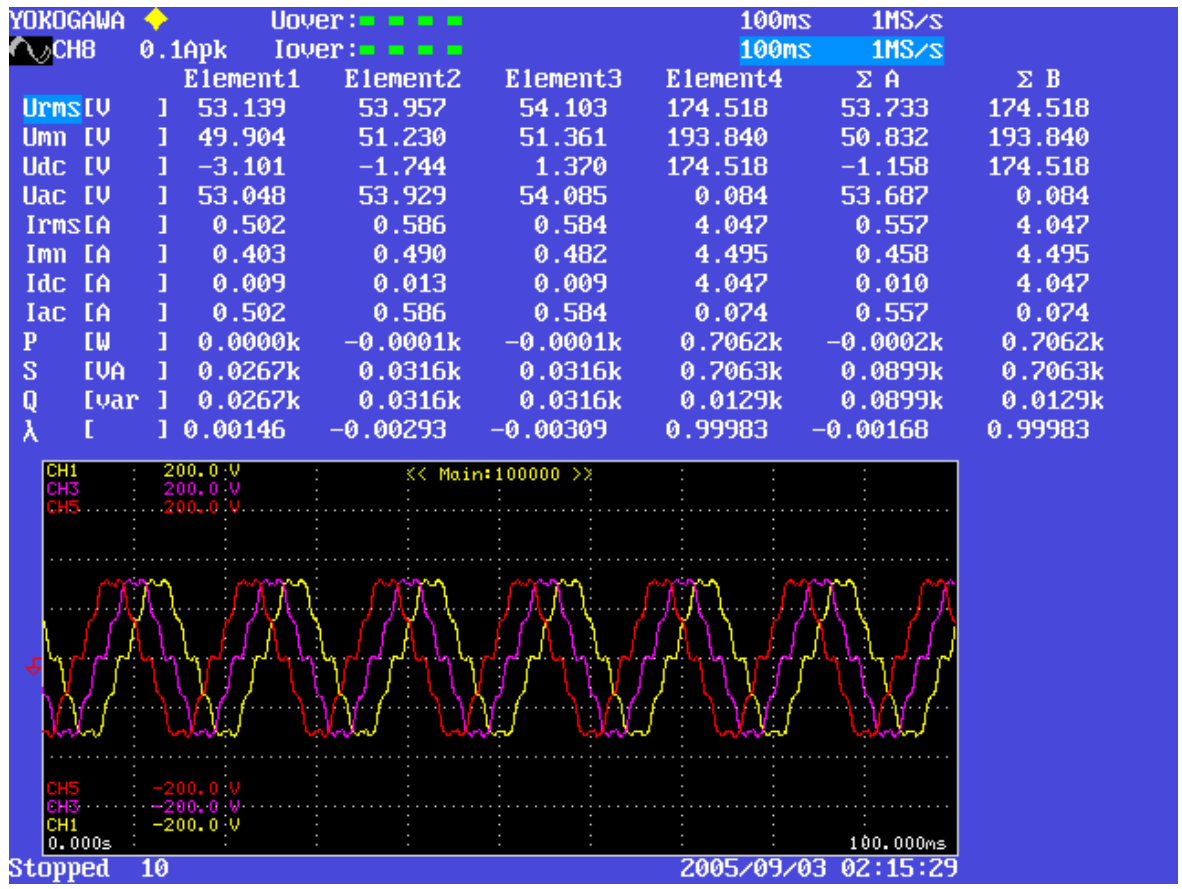

Fig. 41. 0.240 in. thick magnet rotor back-emf at $1000 \mathrm{rpm}$ with field weakening at 4 Adc. 


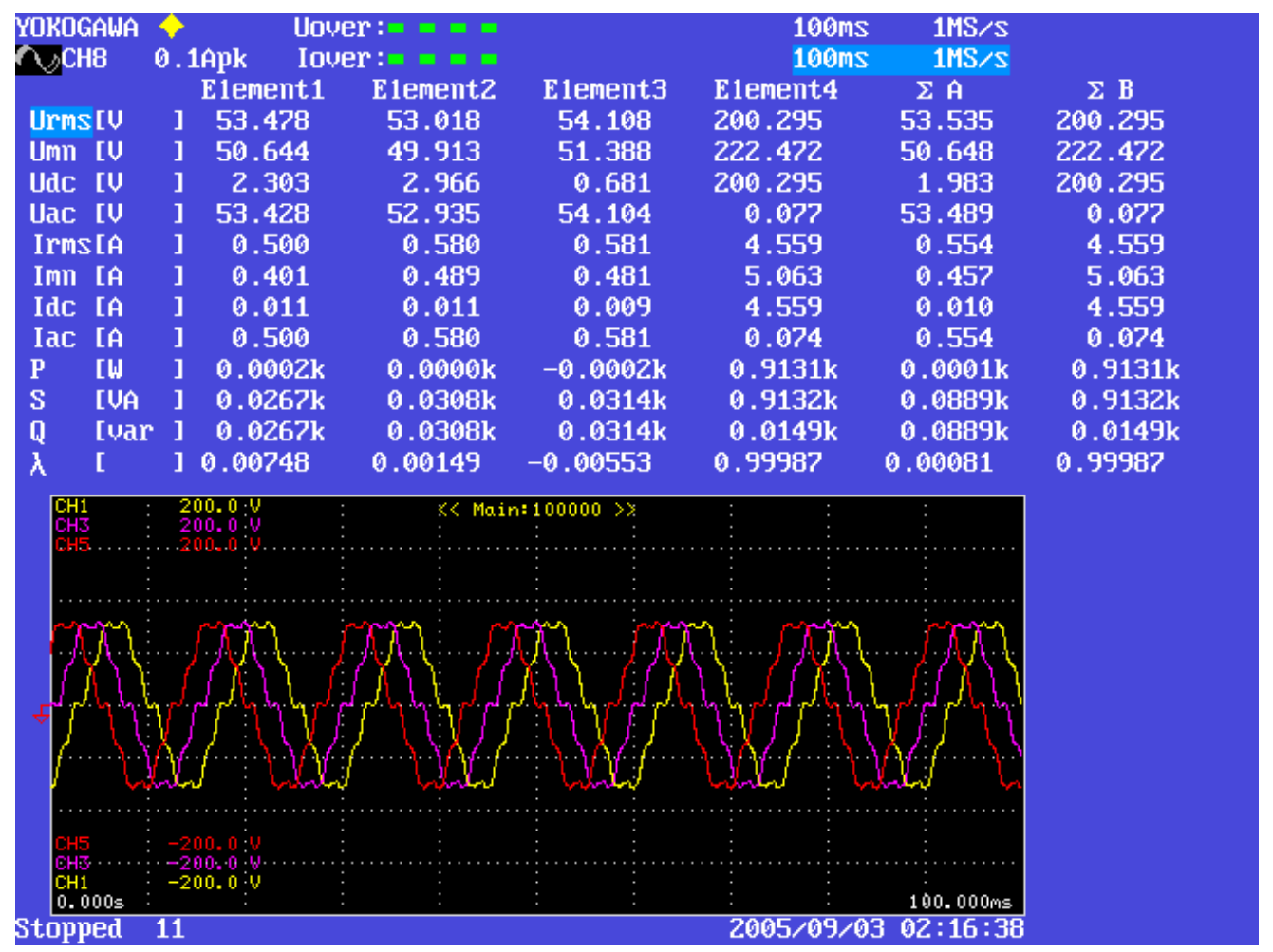

Fig. 42.0 .240 in. thick magnet rotor back-emf at $1000 \mathrm{rpm}$ with field weakening at 5 Adc.

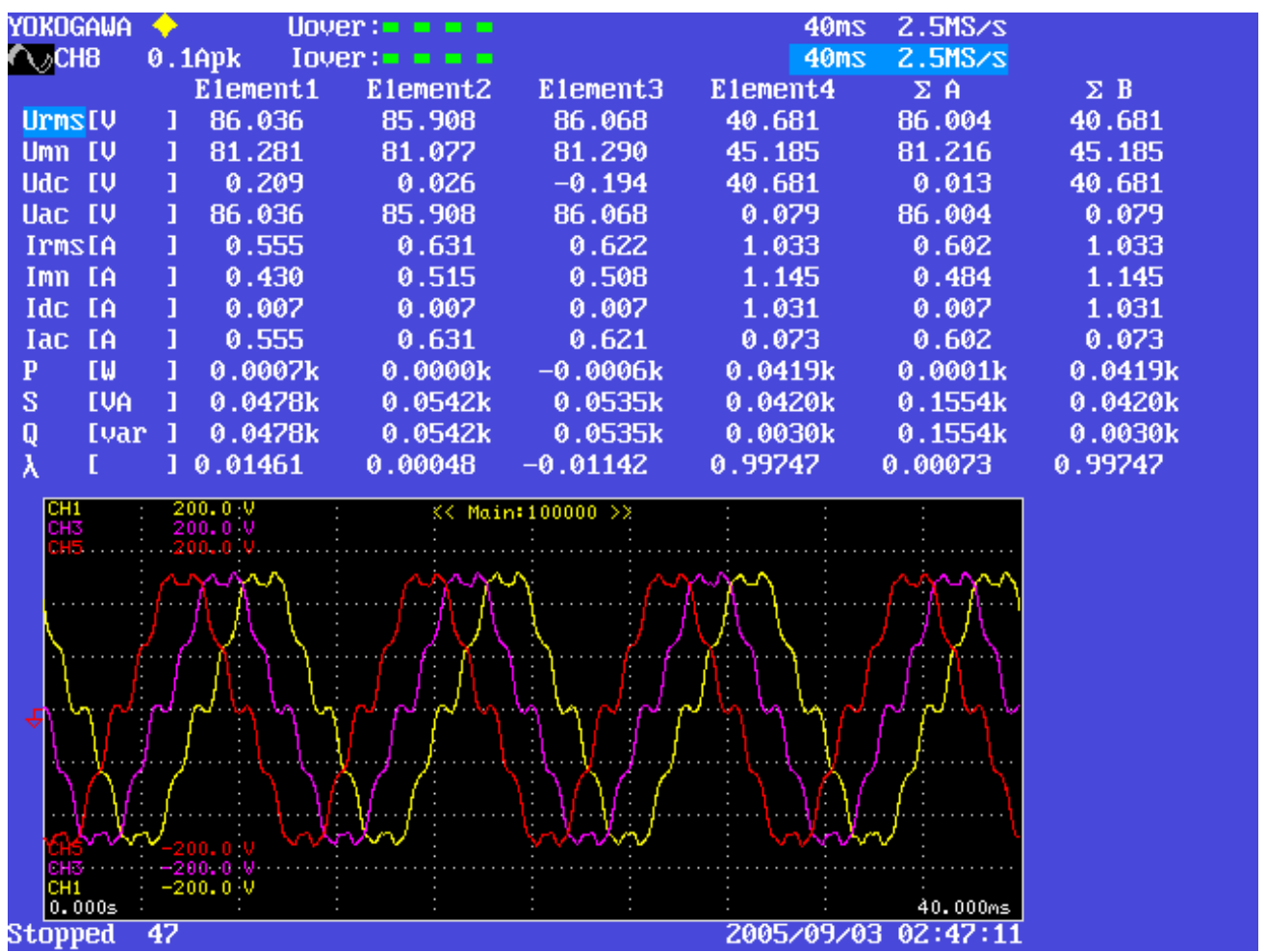

Fig. 43. 0.240 in. thick magnet rotor back-emf at $1500 \mathrm{rpm}$ with field weakening at 1 Adc. 


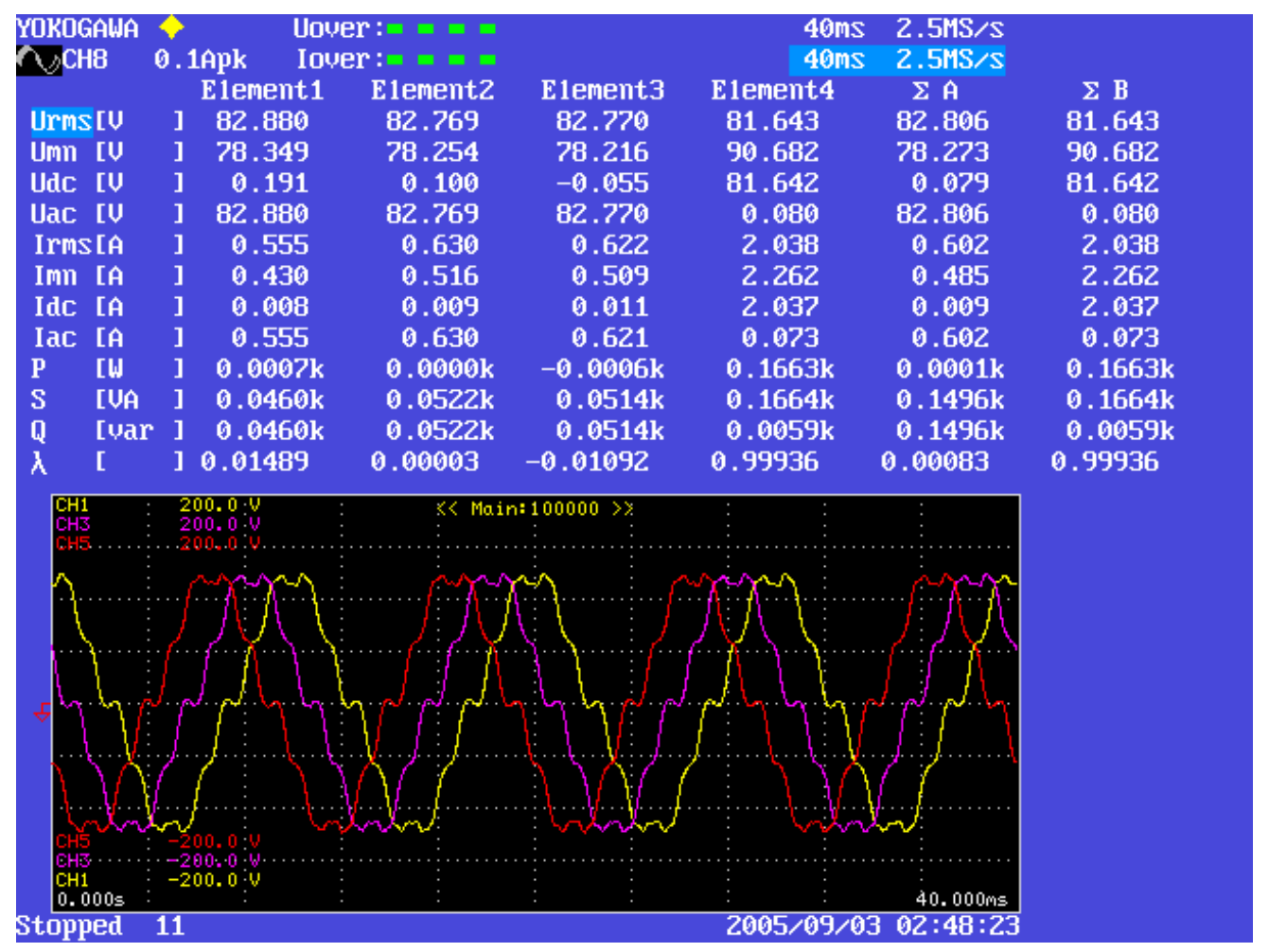

Fig. 44. 0.240 in. thick magnet rotor back-emf at $1500 \mathrm{rpm}$ with field weakening at 2 Adc.

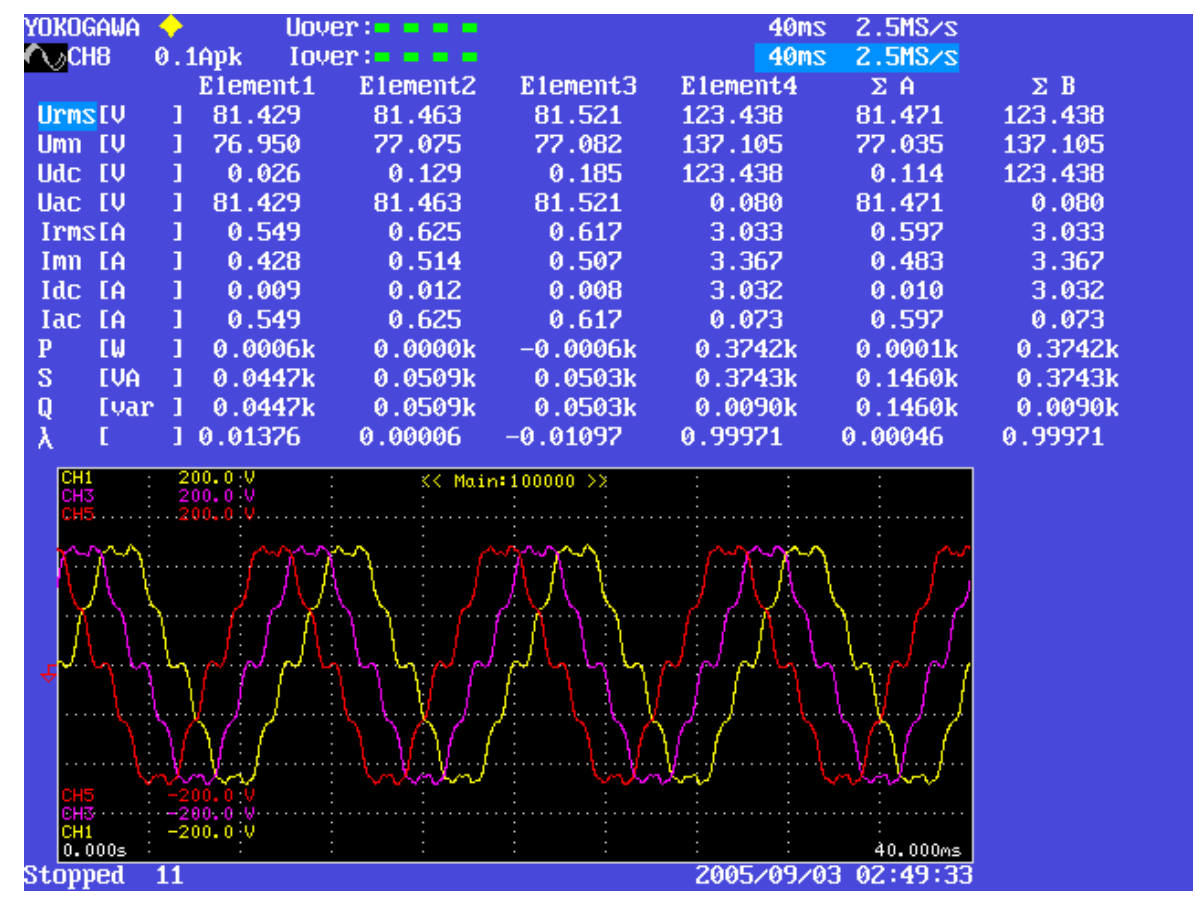

Fig. 45.0 .240 in. thick magnet rotor back-emf at $1500 \mathrm{rpm}$ with field weakening at 3 Adc. 


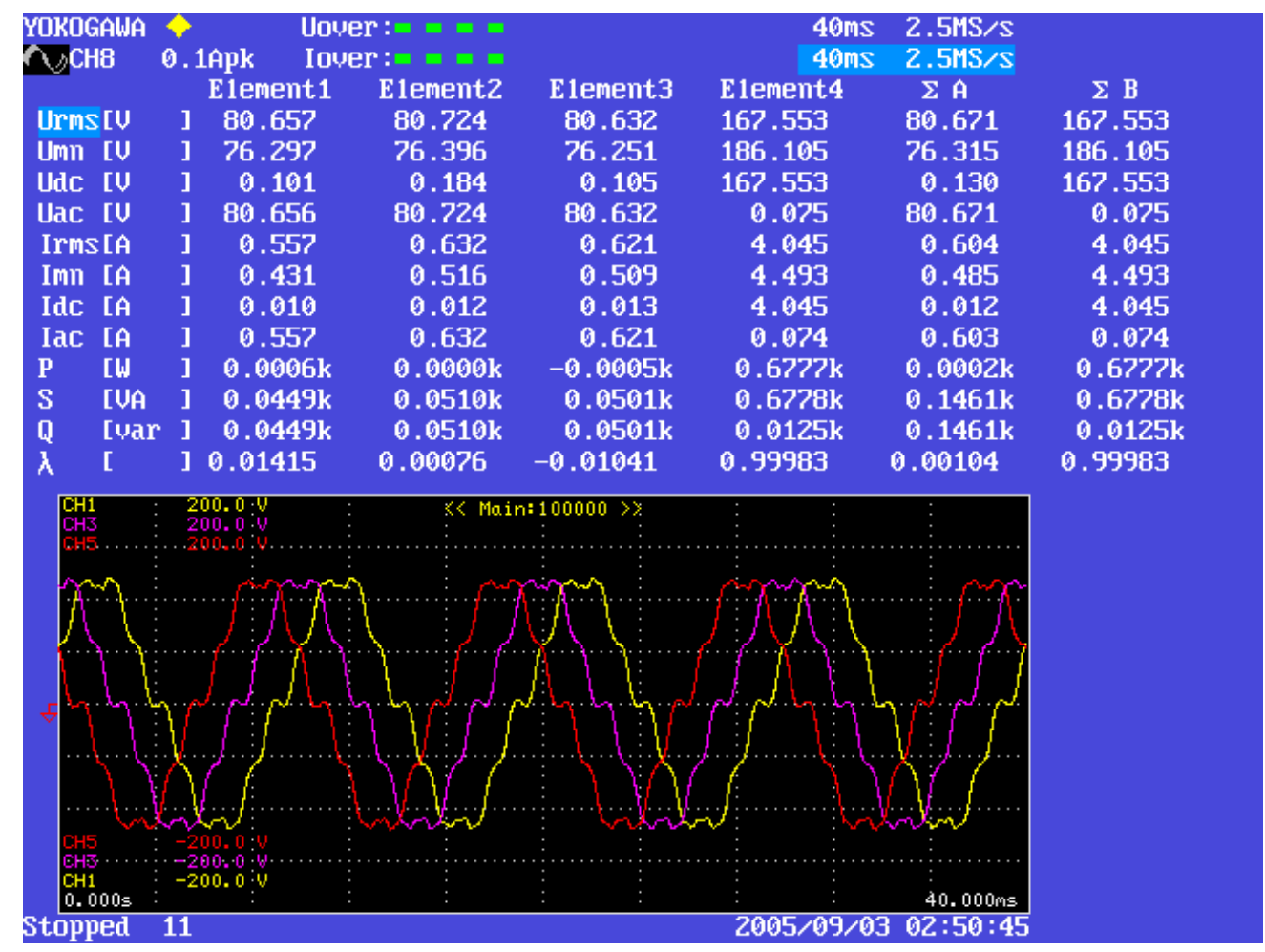

Fig. 46. 0.240 in. thick magnet rotor back-emf at $1500 \mathrm{rpm}$ with field weakening at 4 Adc.

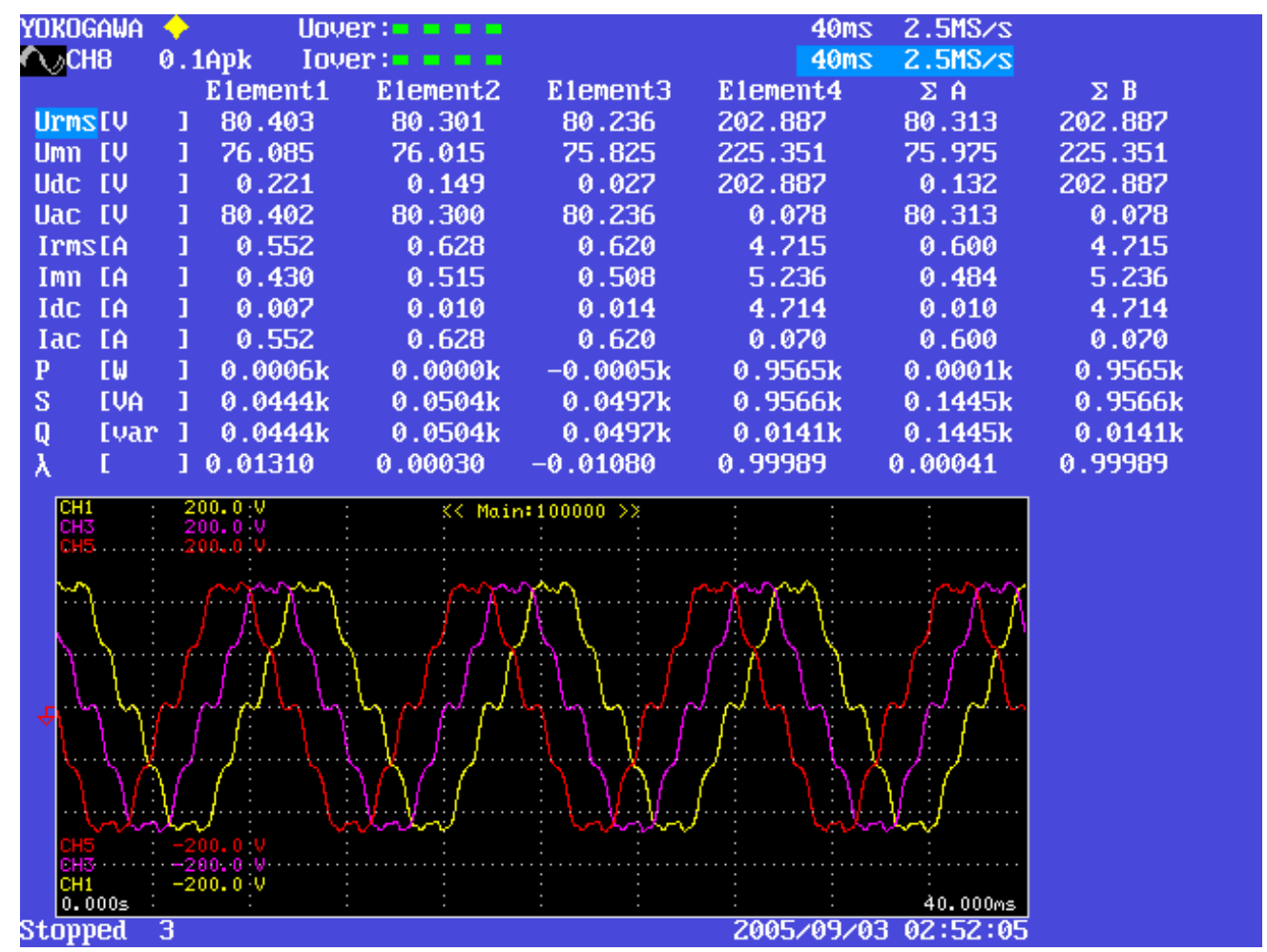

Fig. 47. 0.240 in. thick magnet rotor back-emf at $1500 \mathrm{rpm}$ with field weakening at 5 Adc. 


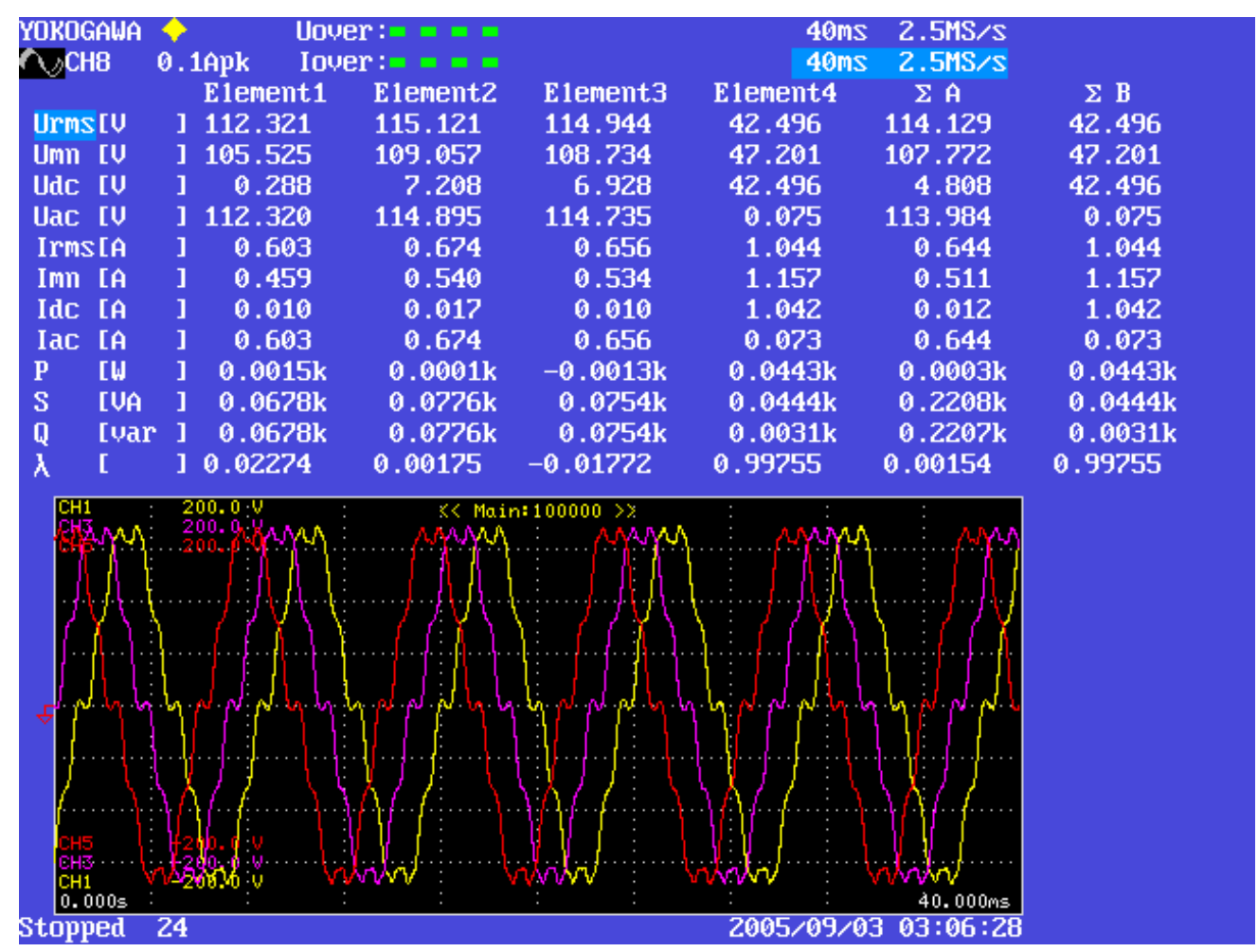

Fig. 48.0 .240 in. thick magnet rotor back-emf $2000 \mathrm{rpm}$ with field weakening at 1 Adc.

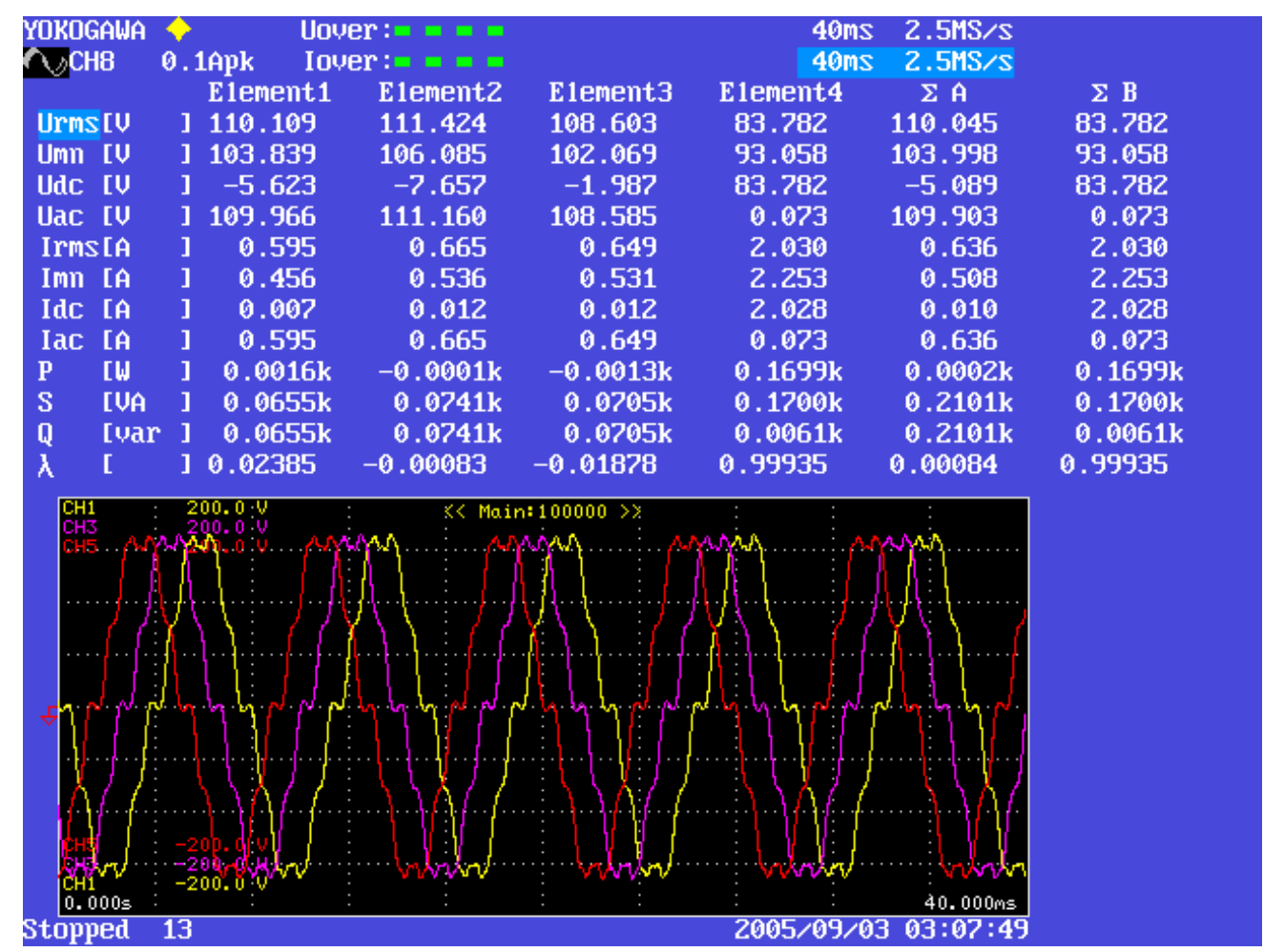

Fig. 49. 0.240 in. thick magnet rotor back-emf $2000 \mathrm{rpm}$ with field weakening at 2 Adc. 


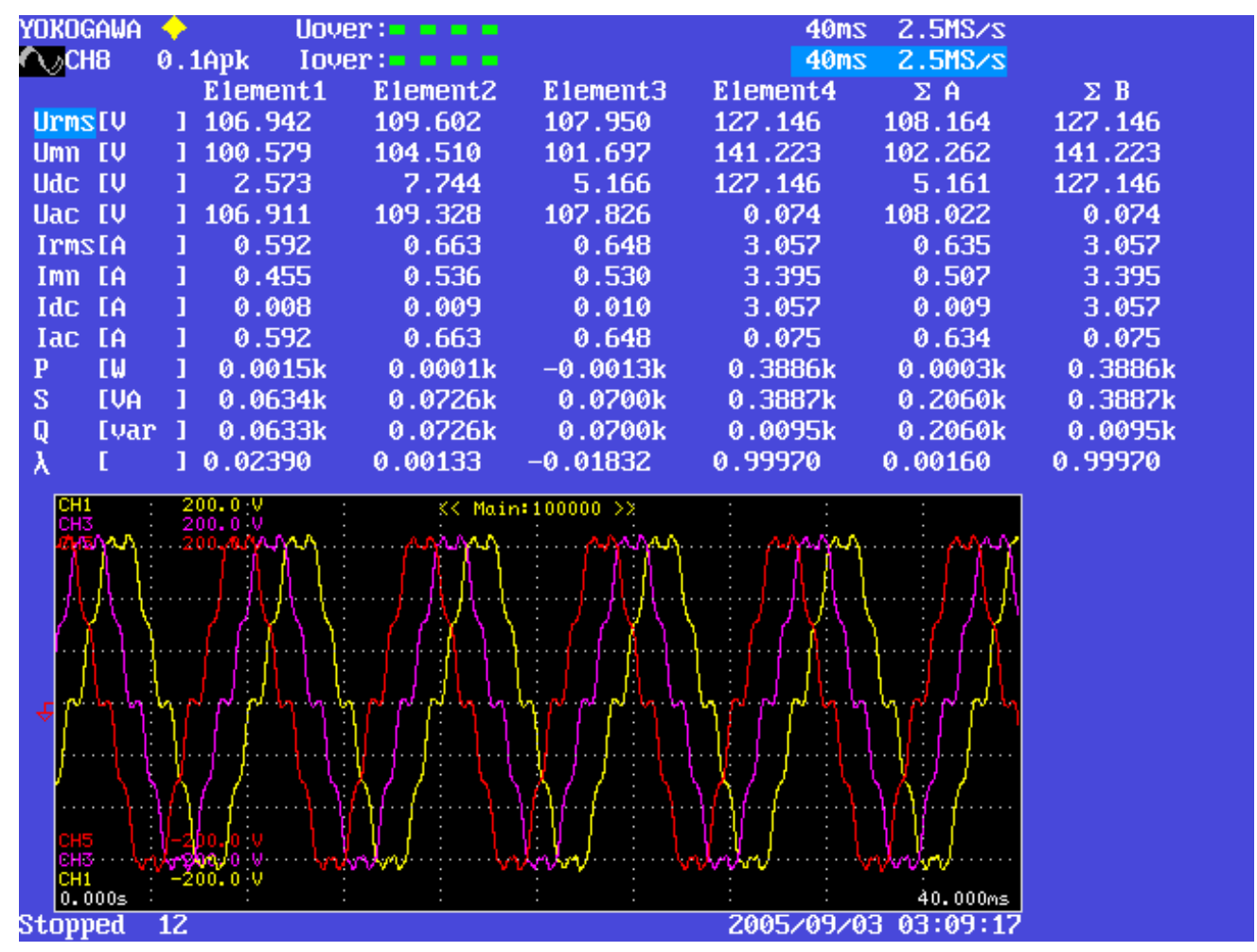

Fig. 50. 0.240 in. thick magnet rotor back-emf $2000 \mathrm{rpm}$ with field weakening at 3 Adc.

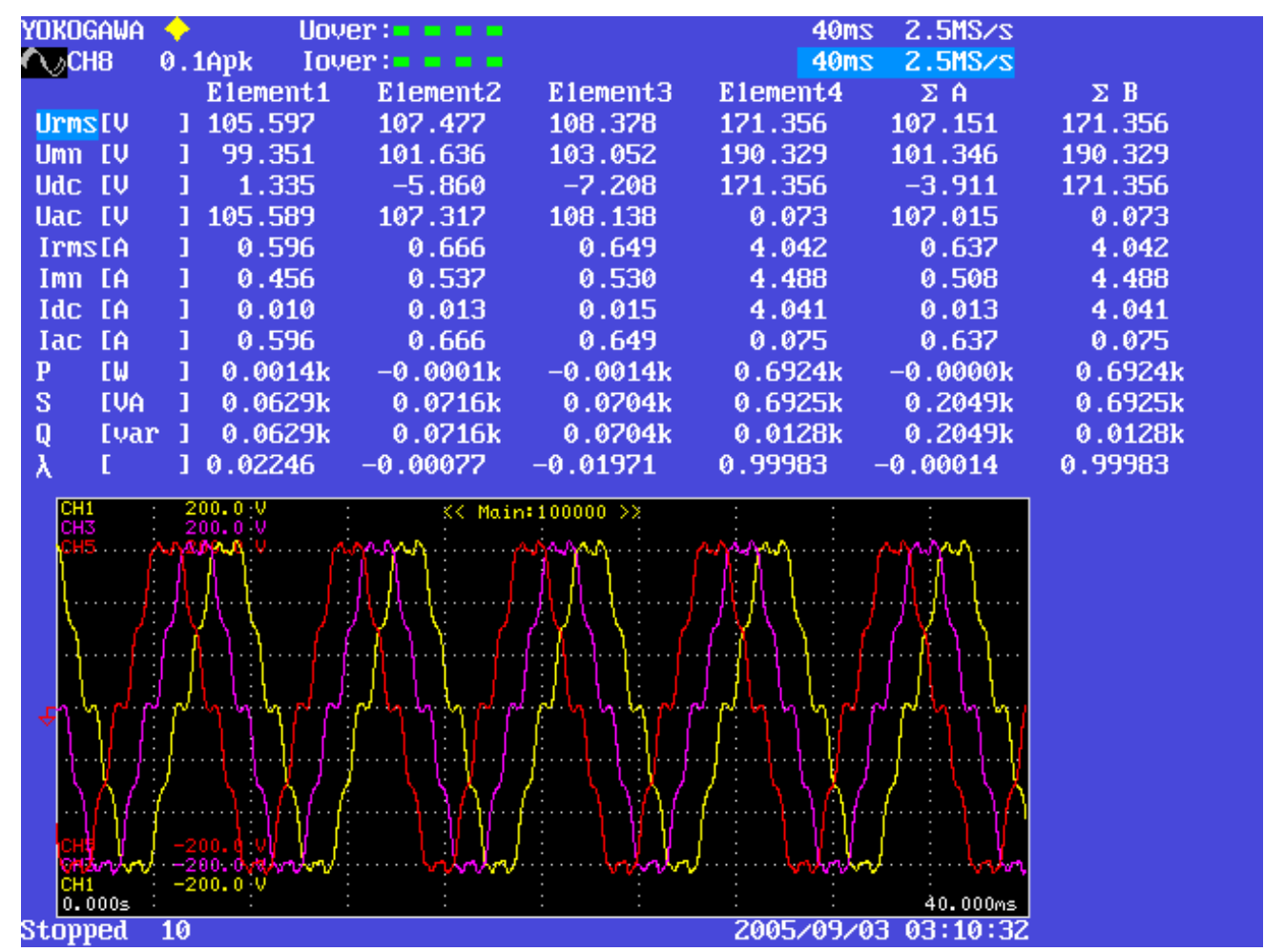

Fig. 51.0 .240 in. thick magnet rotor back-emf 2000 rpm with field weakening at 4 Adc. 


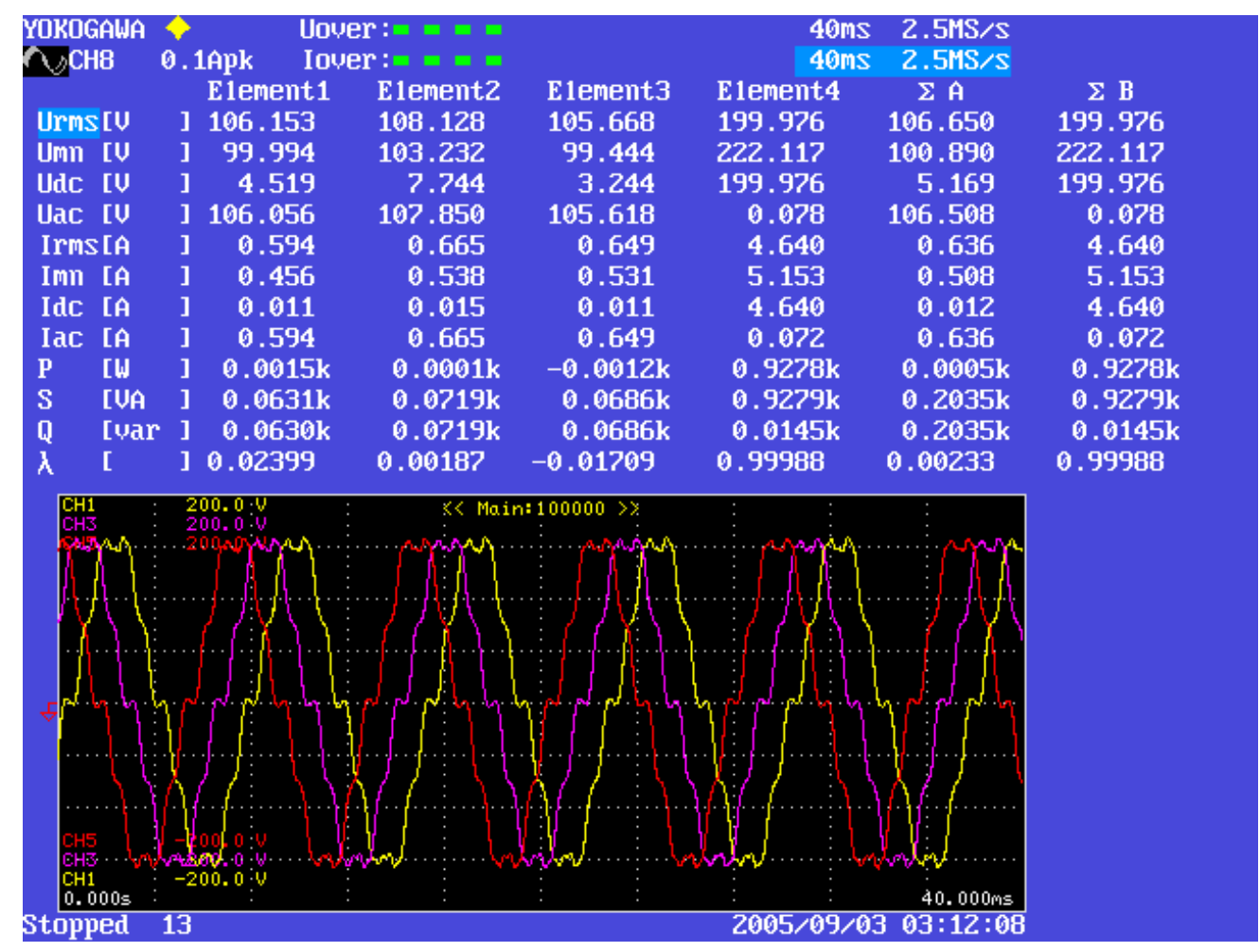

Fig. 52.0 .240 in. thick magnet rotor back-emf $2000 \mathrm{rpm}$ with field weakening at 5 Adc.

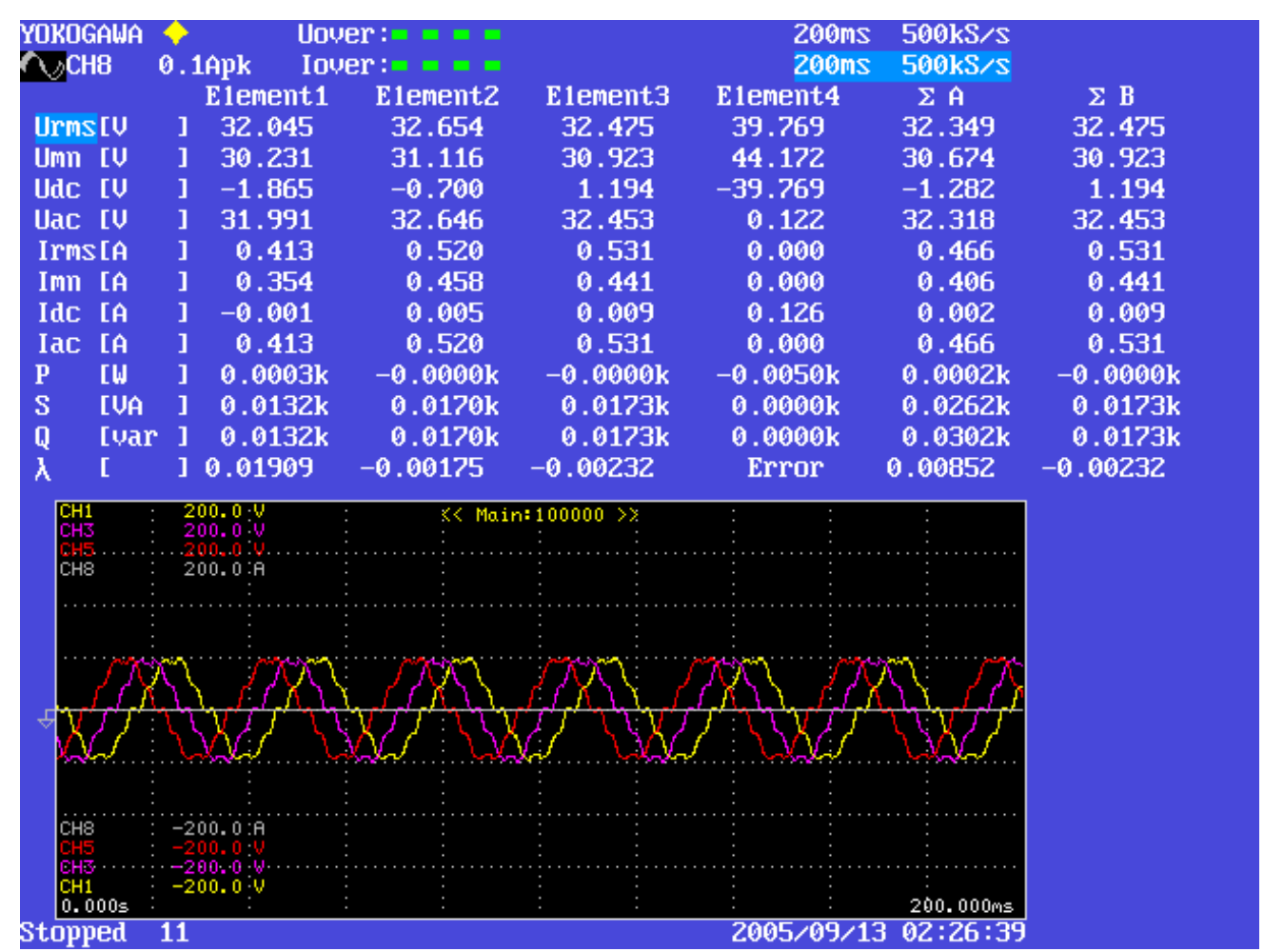

Fig. 53.0 .240 in. thick magnet rotor back-emf at $500 \mathrm{rpm}$ with field enhancement at 1 Adc. 


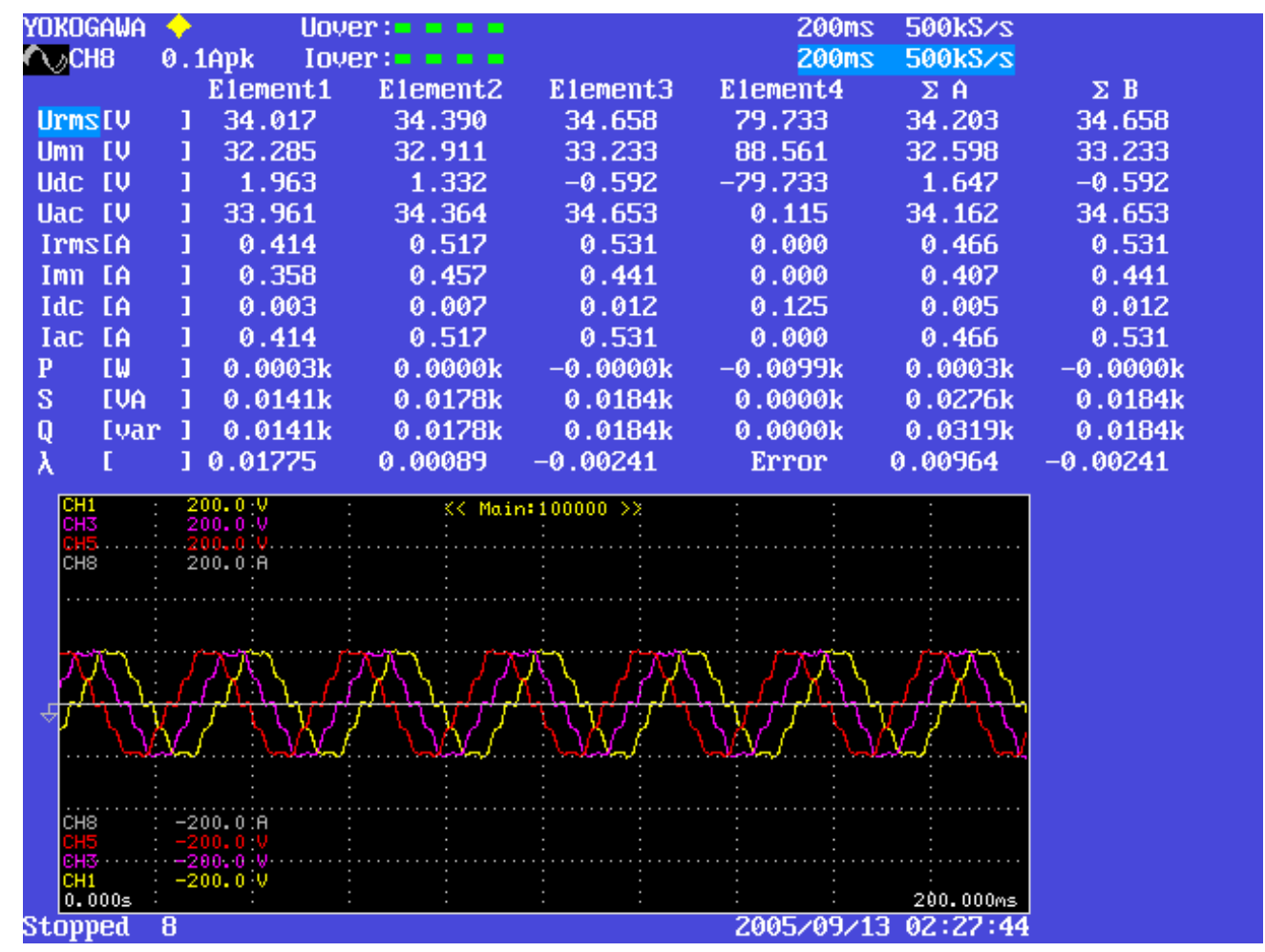

Fig. 54. 0.240 in. thick magnet rotor back-emf at $500 \mathrm{rpm}$ with field enhancement at 2 Adc.

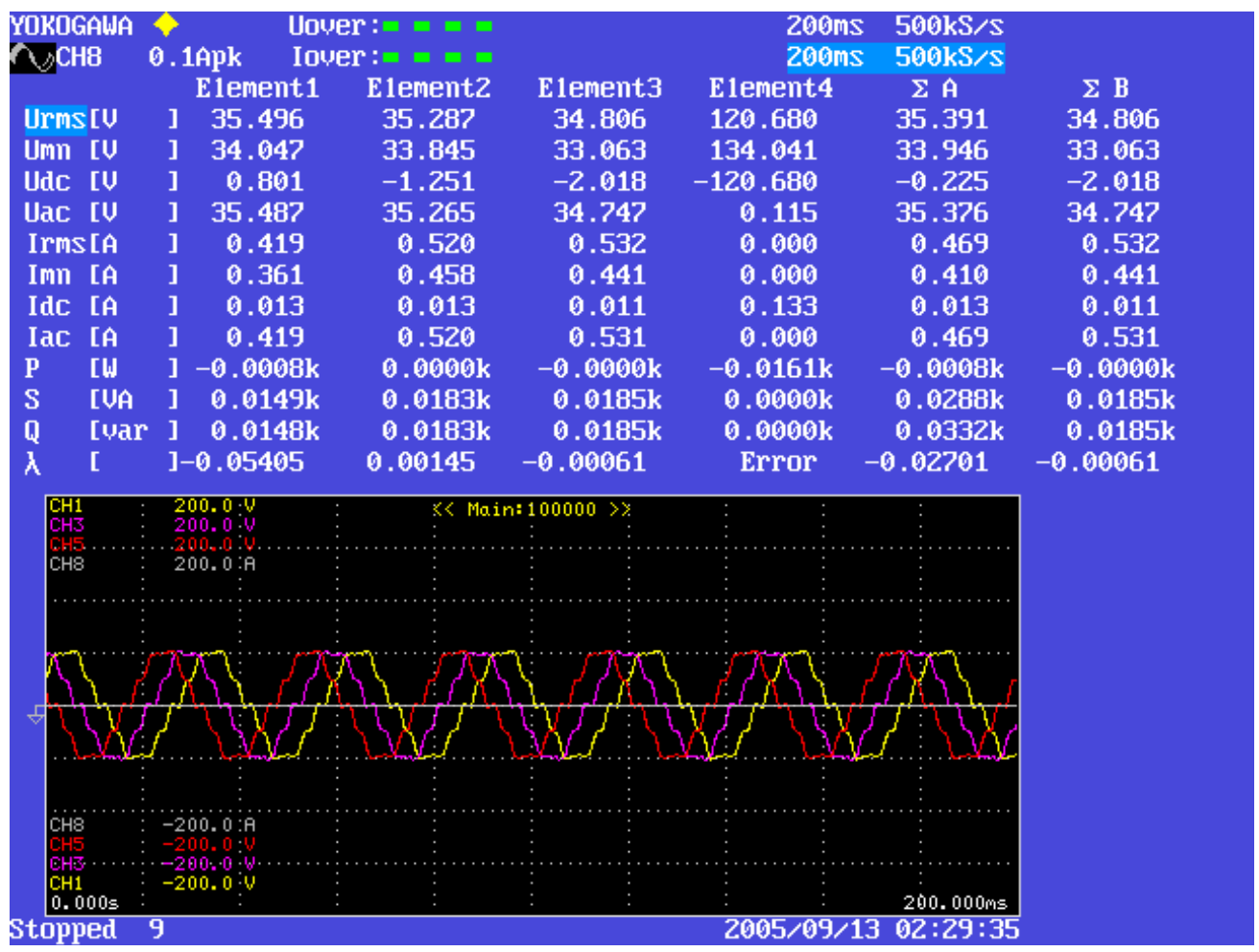

Fig. 55.0 .240 in. thick magnet rotor back-emf at $500 \mathrm{rpm}$ with field enhancement at 3 Adc. 


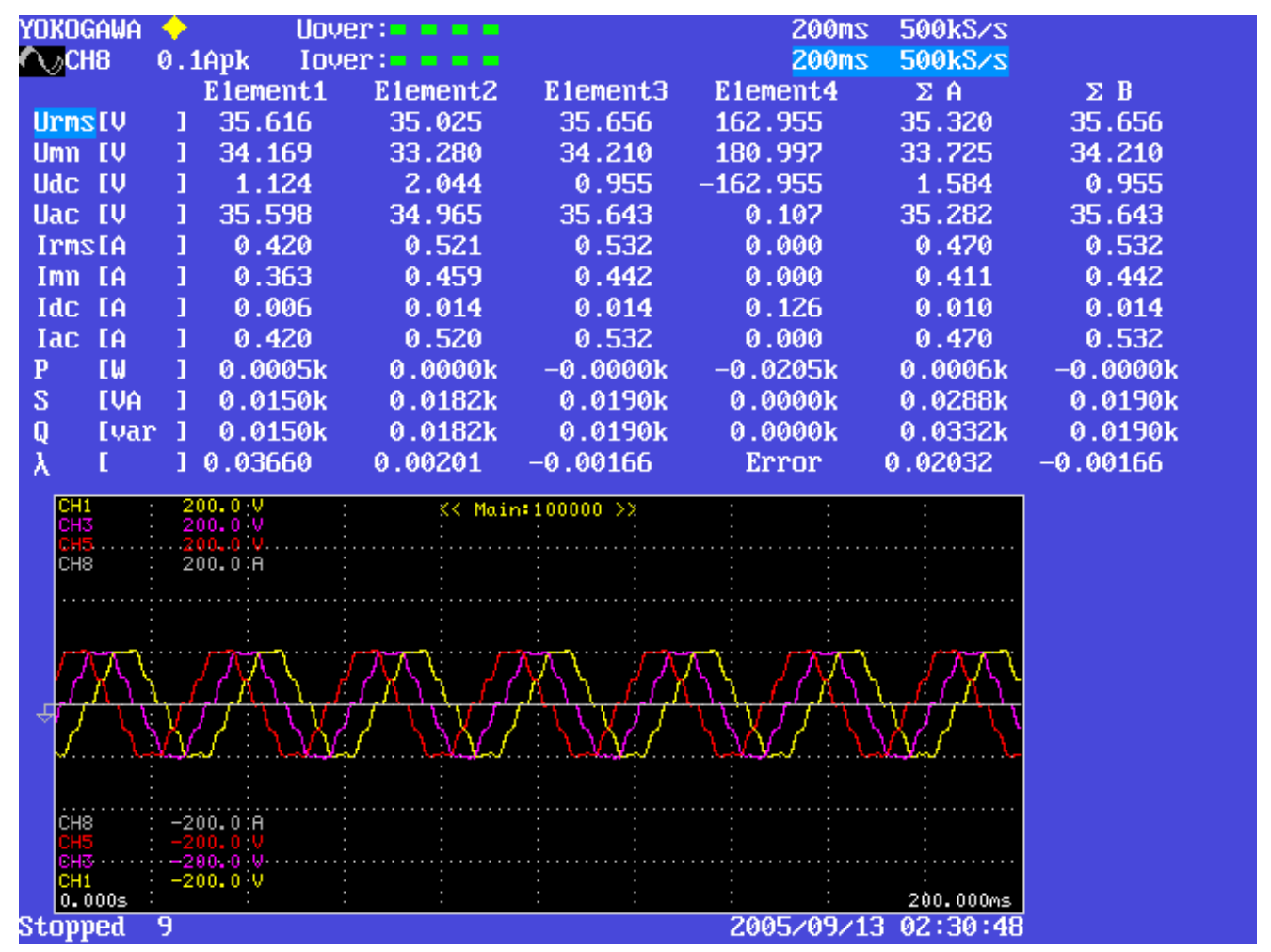

Fig. 56.0 .240 in. thick magnet rotor back-emf at $500 \mathrm{rpm}$ with field enhancement at 4 Adc.

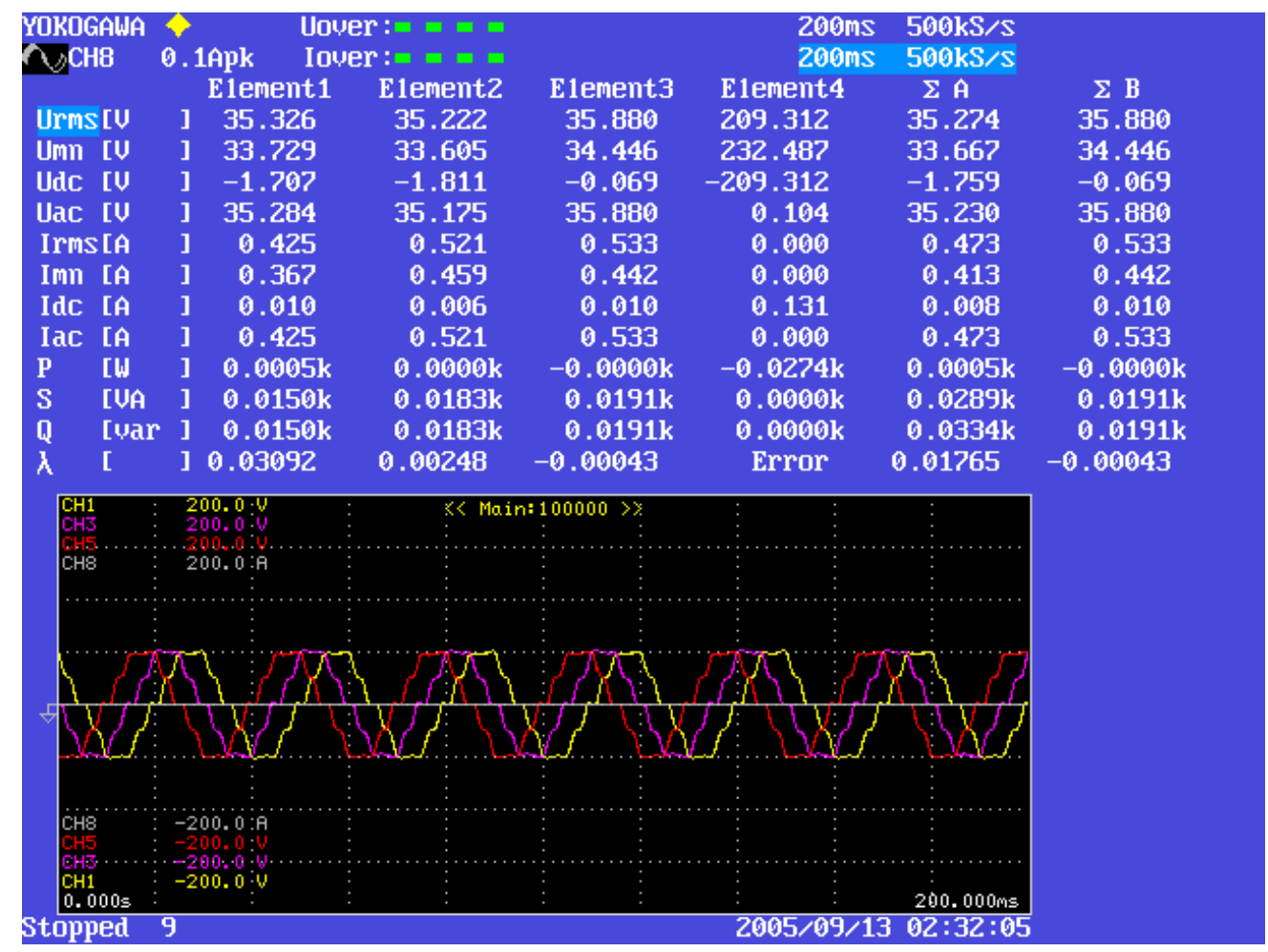

Fig. 57. 0.240 in. thick magnet rotor back-emf at $500 \mathrm{rpm}$ with field enhancement at 5 Adc. 


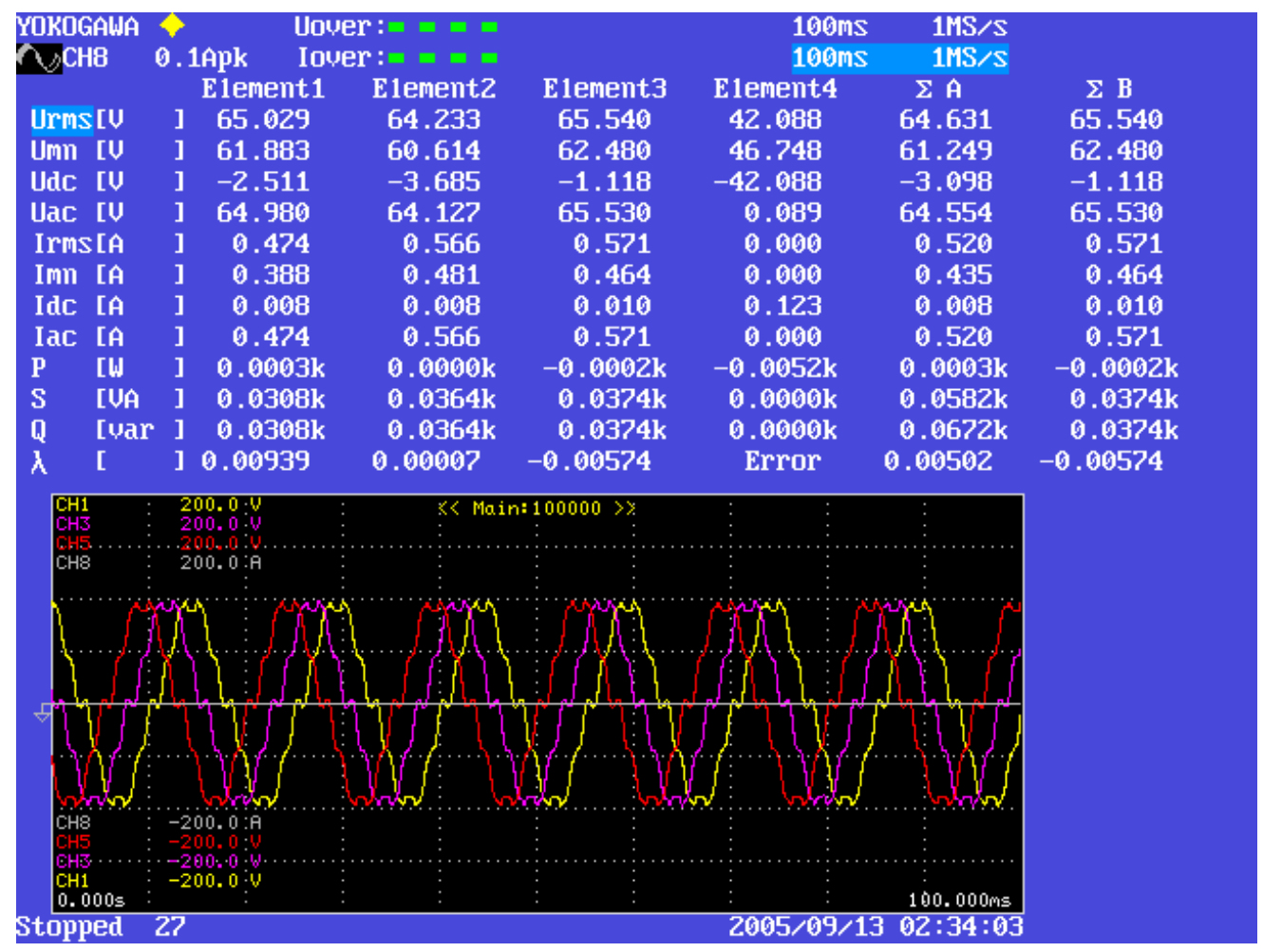

Fig. 58. 0.240 in. thick magnet rotor back-emf at $1000 \mathrm{rpm}$ with field enhancement at 1 Adc.

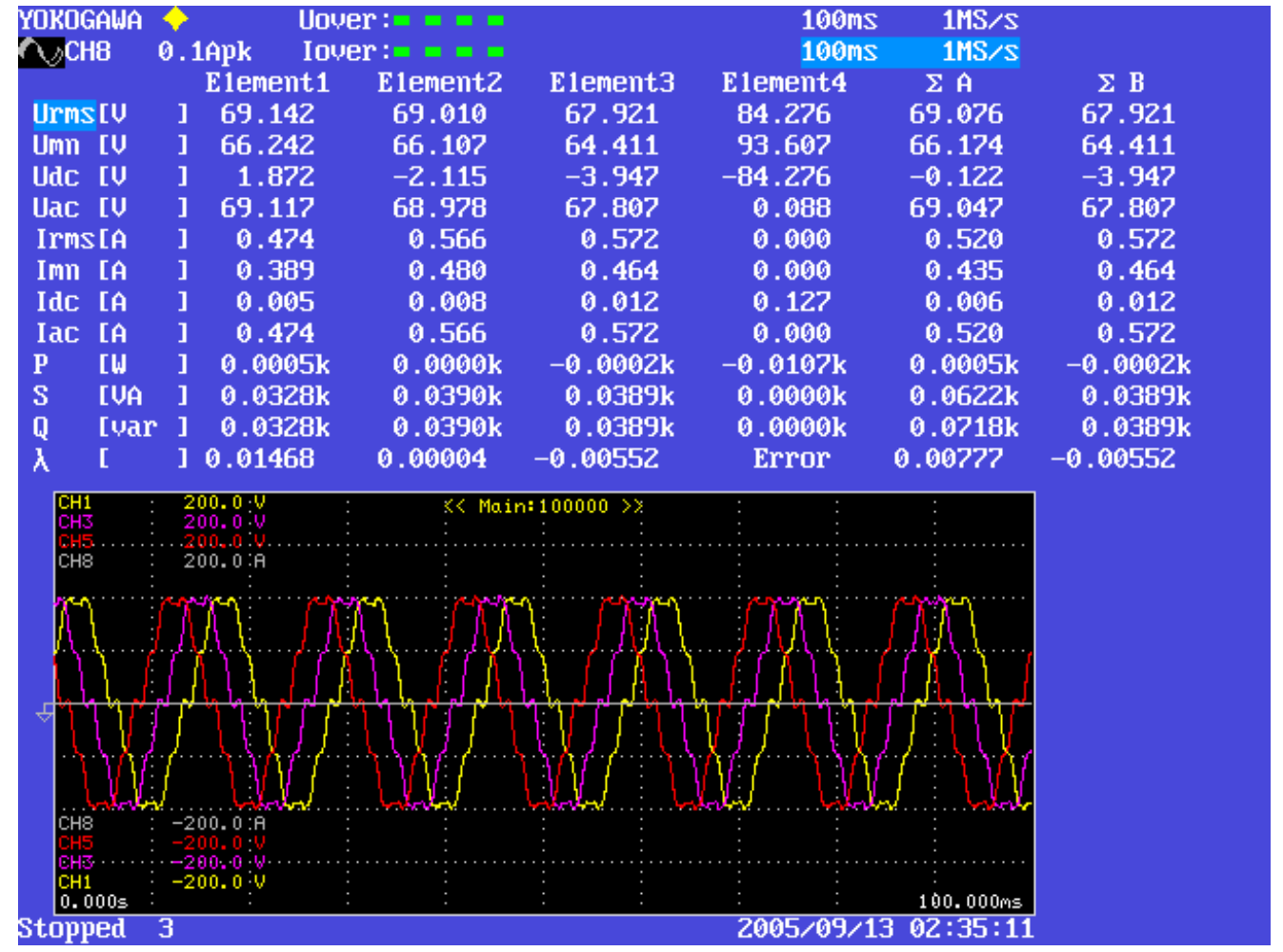

Fig. 59. 0.240 in. thick magnet rotor back-emf at $1000 \mathrm{rpm}$ with field enhancement at 2 Adc. 


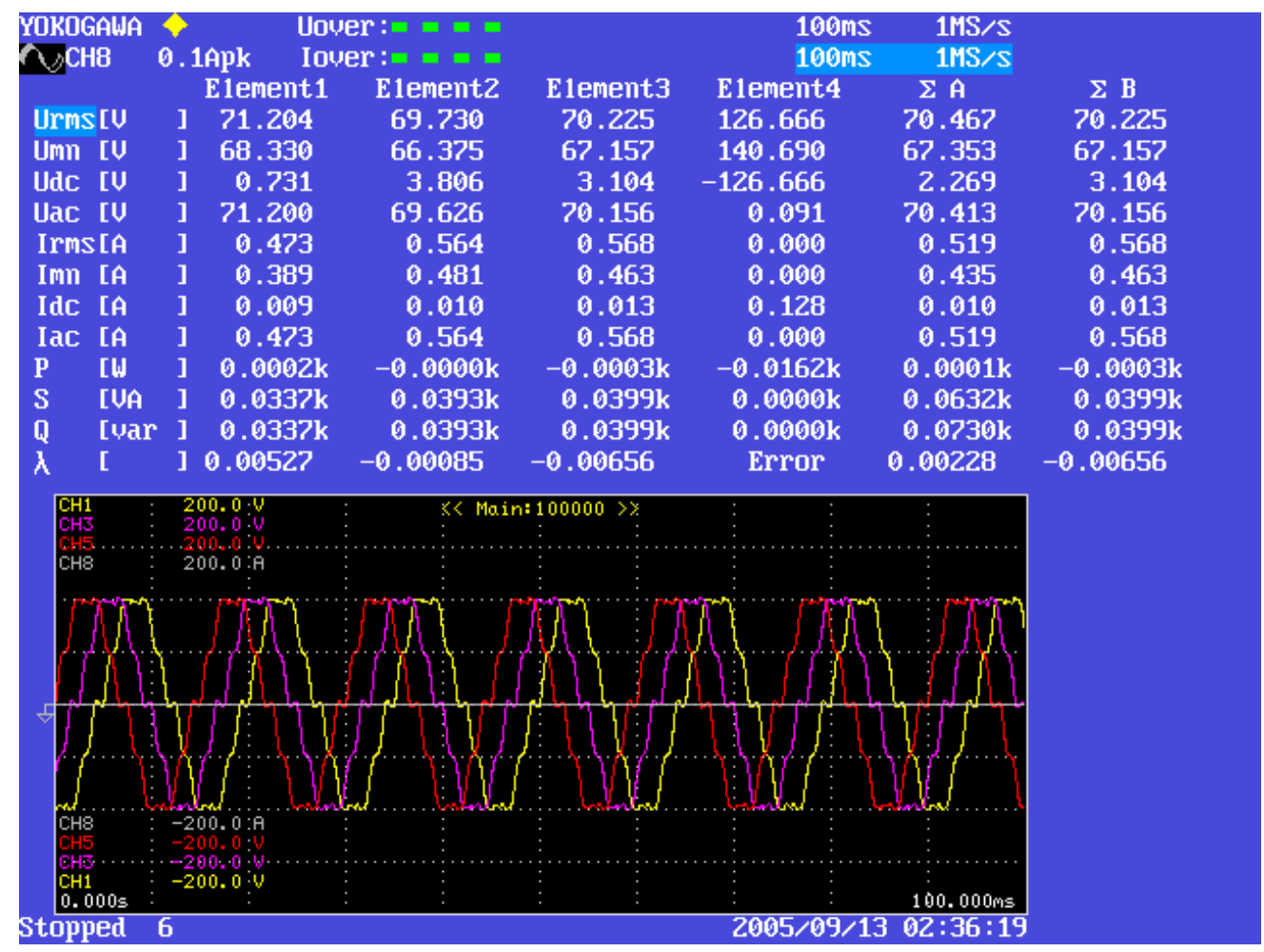

Fig. 60. 0.240 in. thick magnet rotor back-emf at $1000 \mathrm{rpm}$ with field enhancement at 3 Adc.

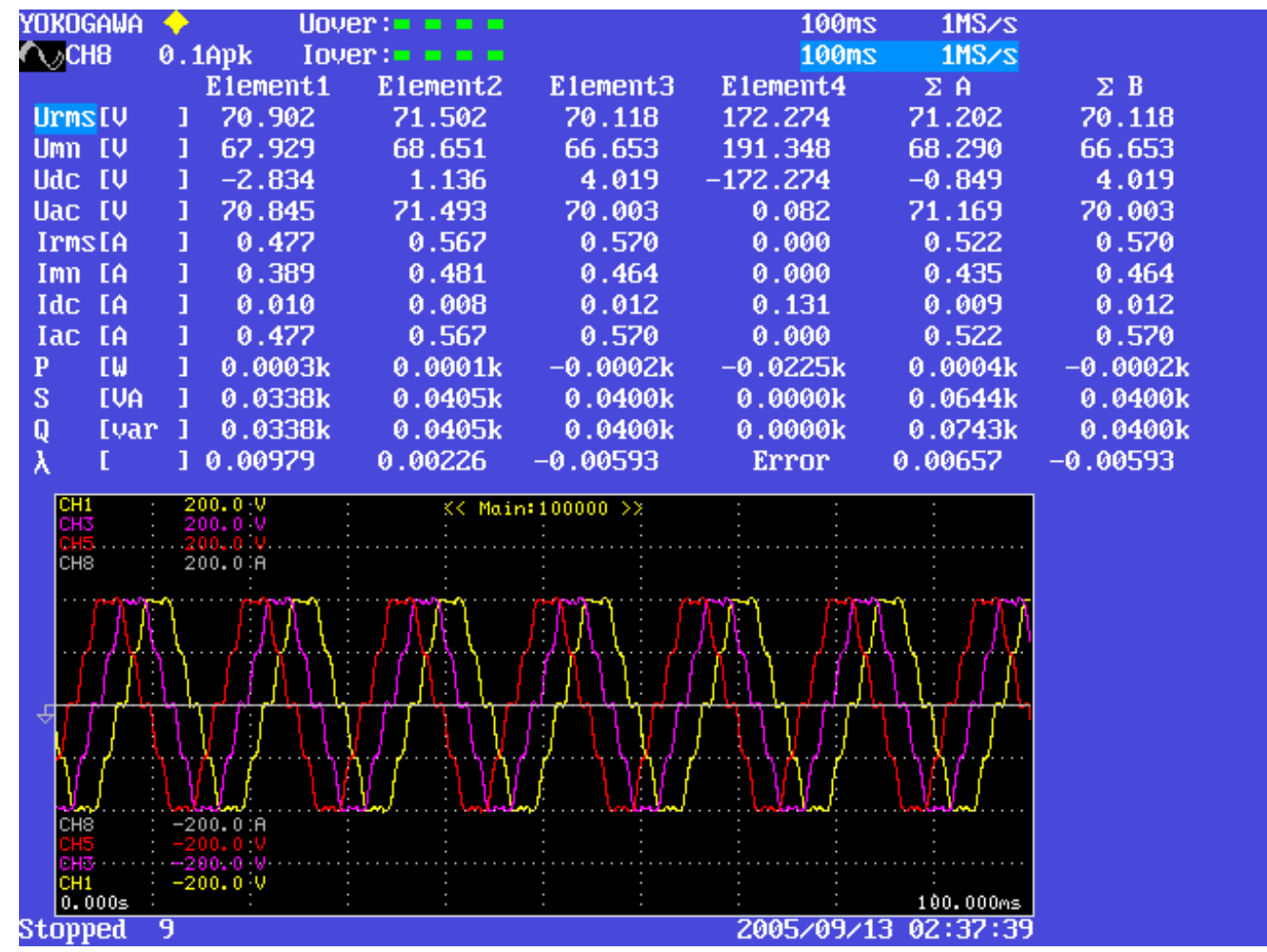

Fig. 61.0 .240 in. thick magnet rotor back-emf at $1000 \mathrm{rpm}$ with field enhancement at 4 Adc. 


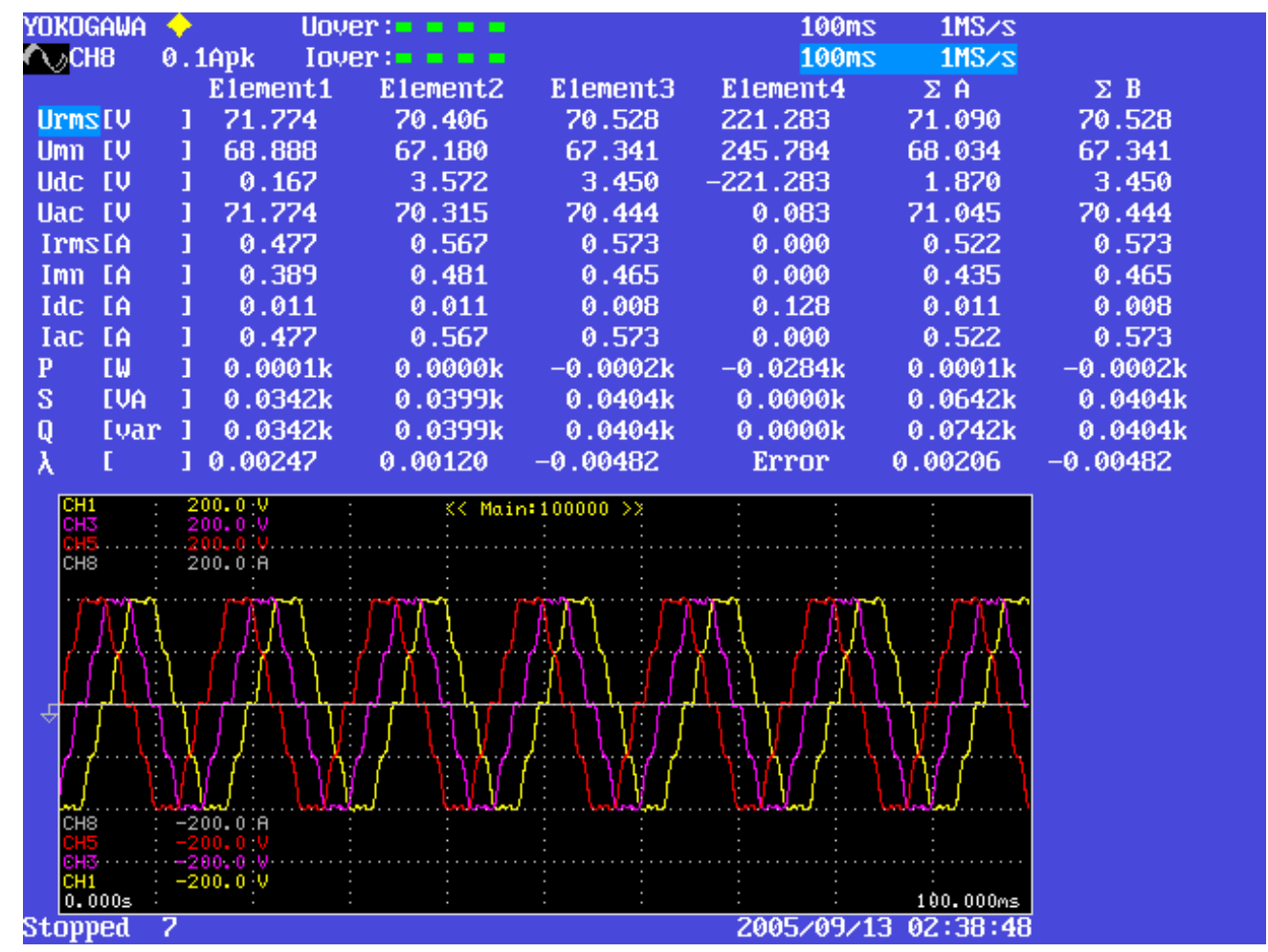

Fig. 62.0 .240 in. thick magnet rotor back-emf at $1000 \mathrm{rpm}$ with field enhancement at 5 Adc.

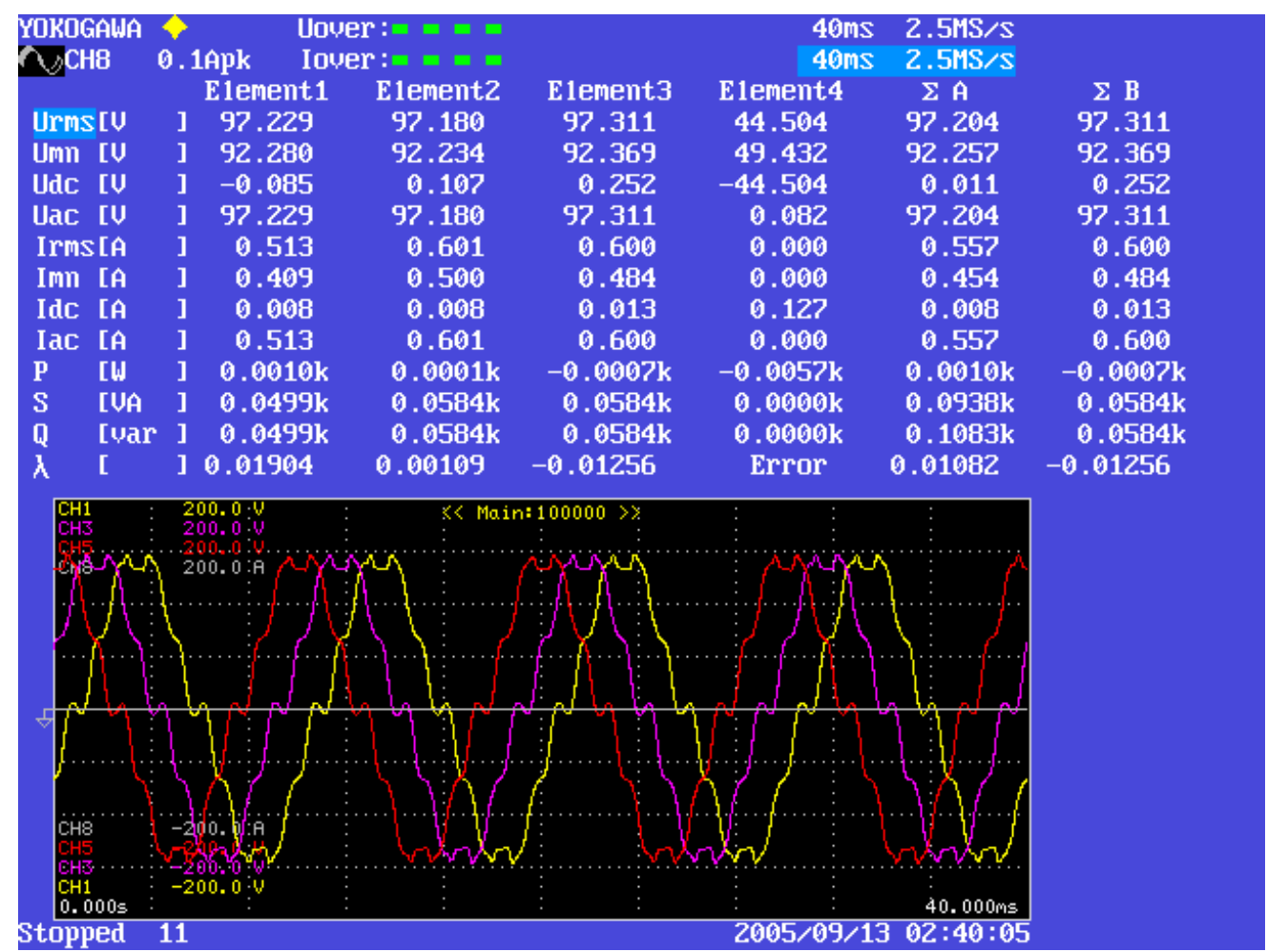

Fig. 63.0 .240 in. thick magnet rotor back-emf at $1500 \mathrm{rpm}$ with field enhancement at 1 Adc. 


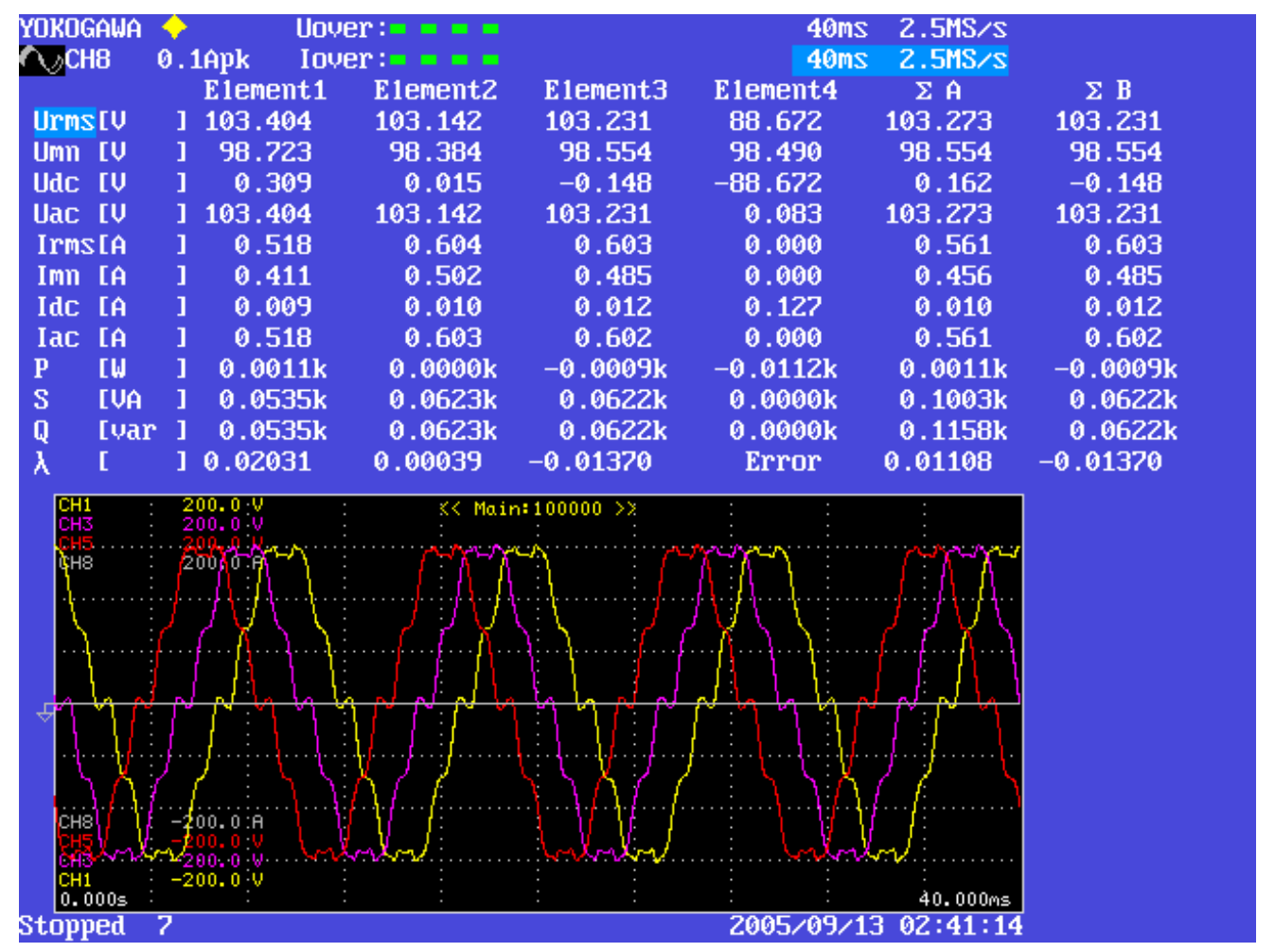

Fig. 64. 0.240 in. thick magnet rotor back-emf at $1500 \mathrm{rpm}$ with field enhancement at 2 Adc.

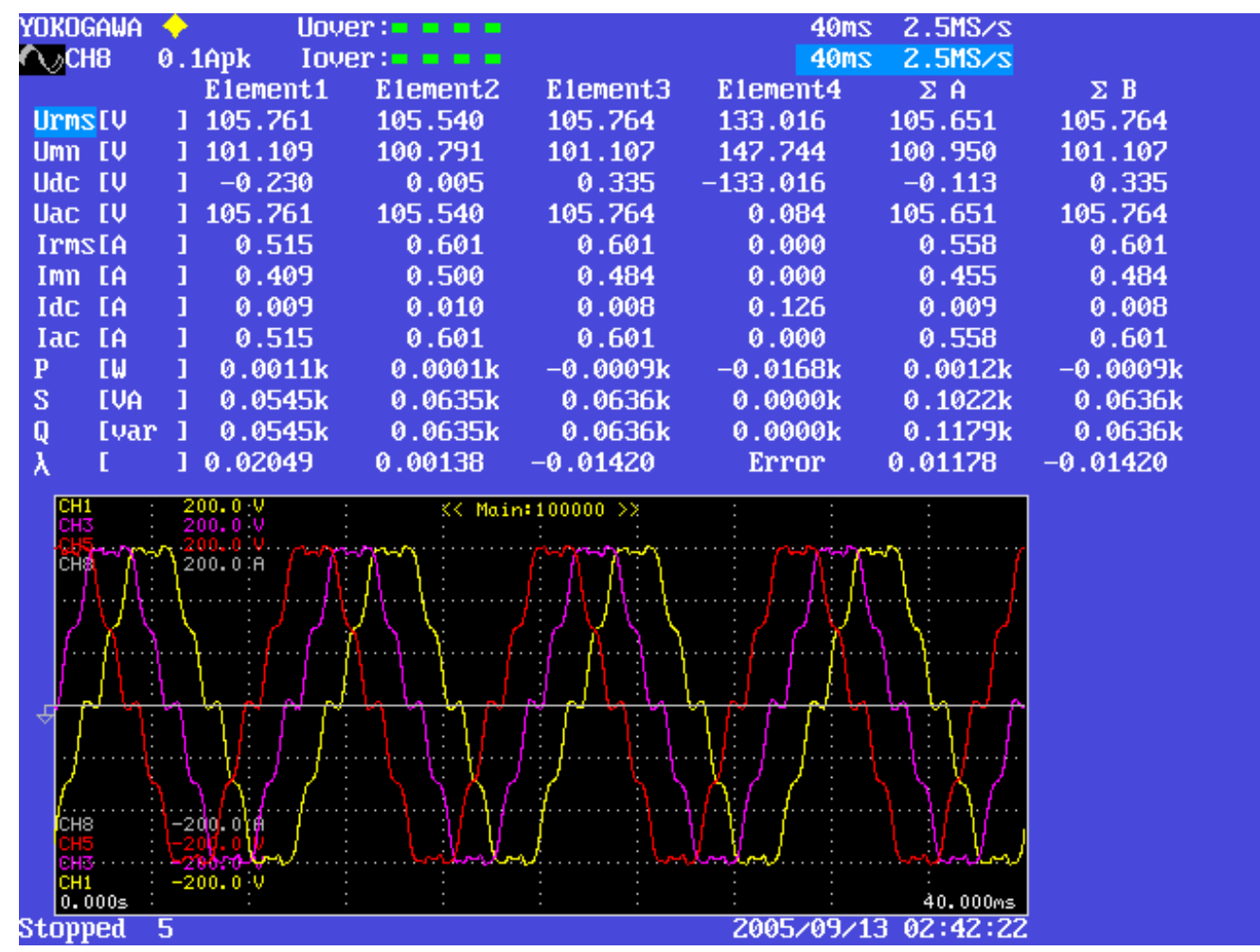

Fig. 65. 0.240 in. thick magnet rotor back-emf at $1500 \mathrm{rpm}$ with field enhancement at 3 Adc. 


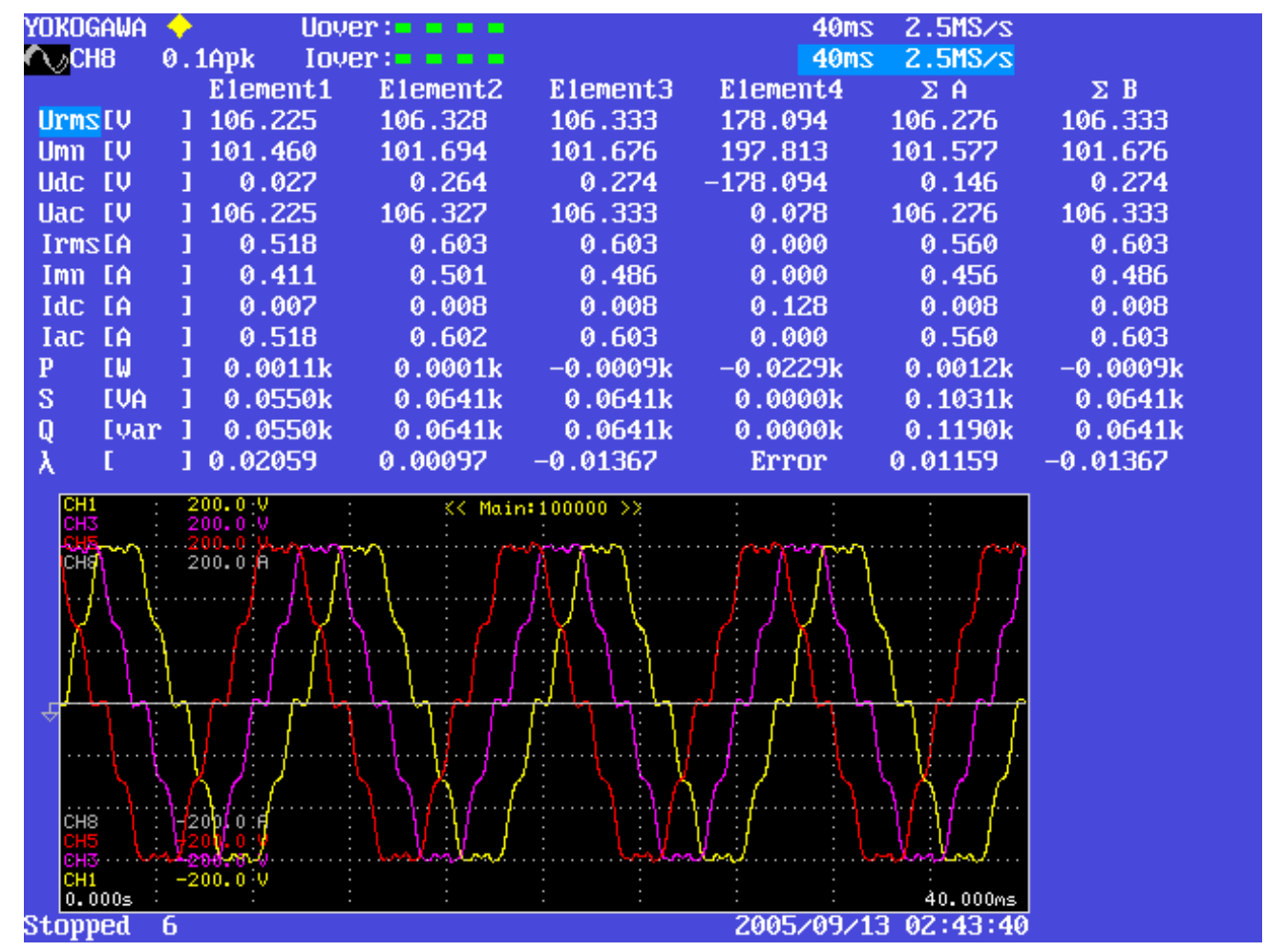

Fig. 66. 0.240 in. thick magnet rotor back-emf at $1500 \mathrm{rpm}$ with field enhancement at 4 Adc.

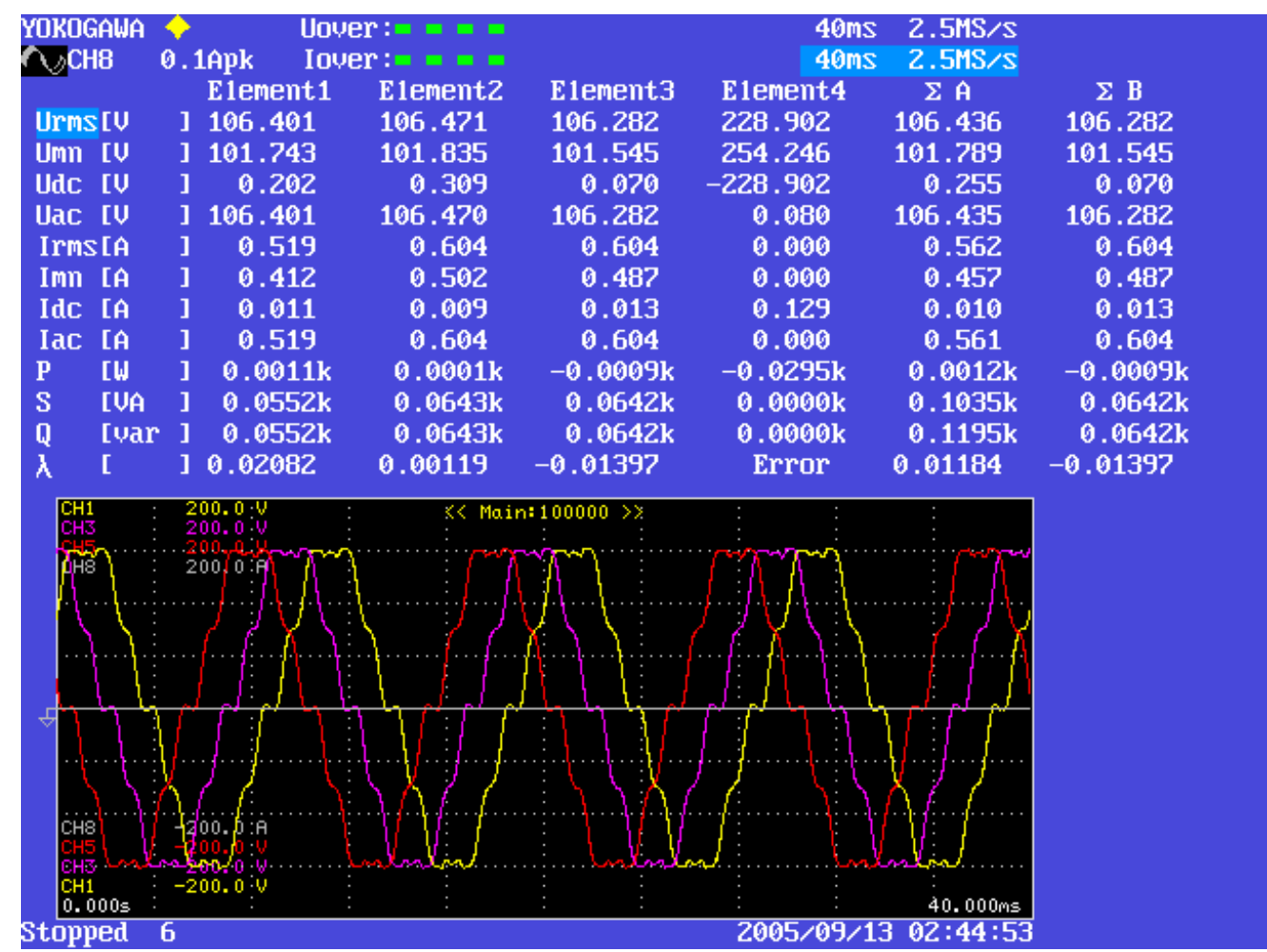

Fig. 67.0 .240 in. thick magnet rotor back-emf at $1500 \mathrm{rpm}$ with field enhancement at 5 Adc. 


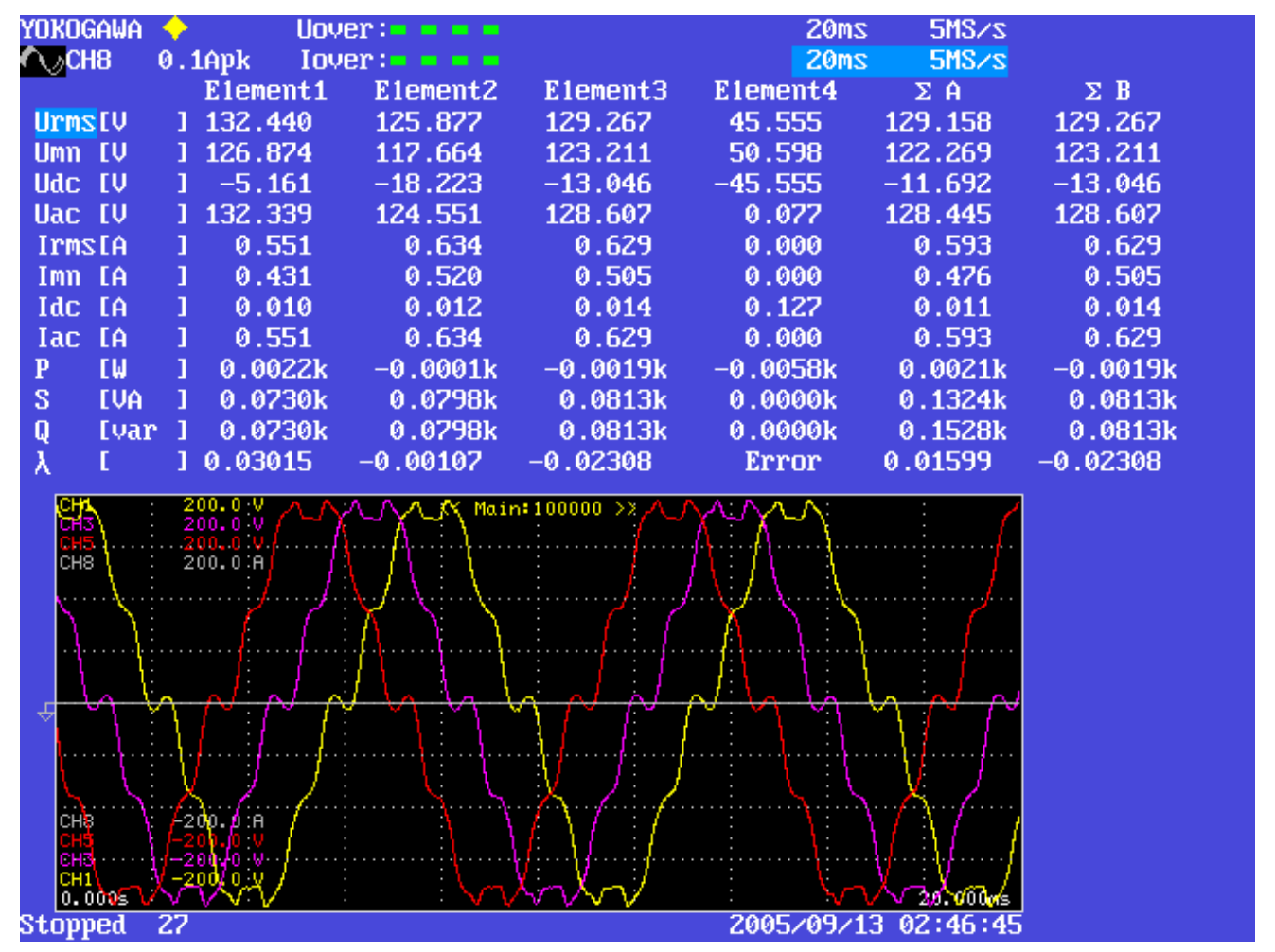

Fig. 68. $0.240 \mathrm{in}$. thick magnet rotor back-emf at $2000 \mathrm{rpm}$ with field enhancement at 1 Adc.

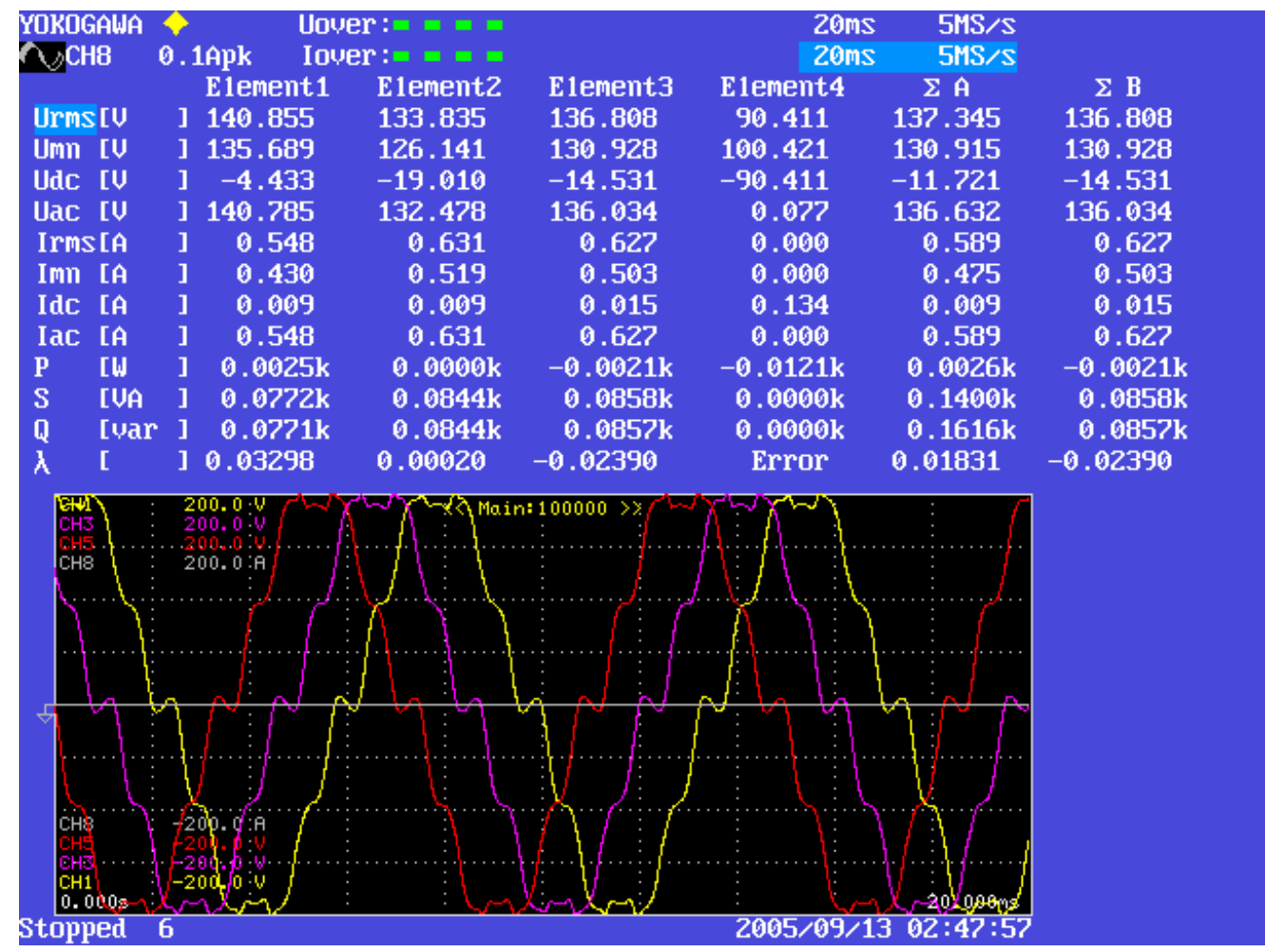

Fig. 69. 0.240 in. thick magnet rotor back-emf at $2000 \mathrm{rpm}$ with field enhancement at 2 Adc. 


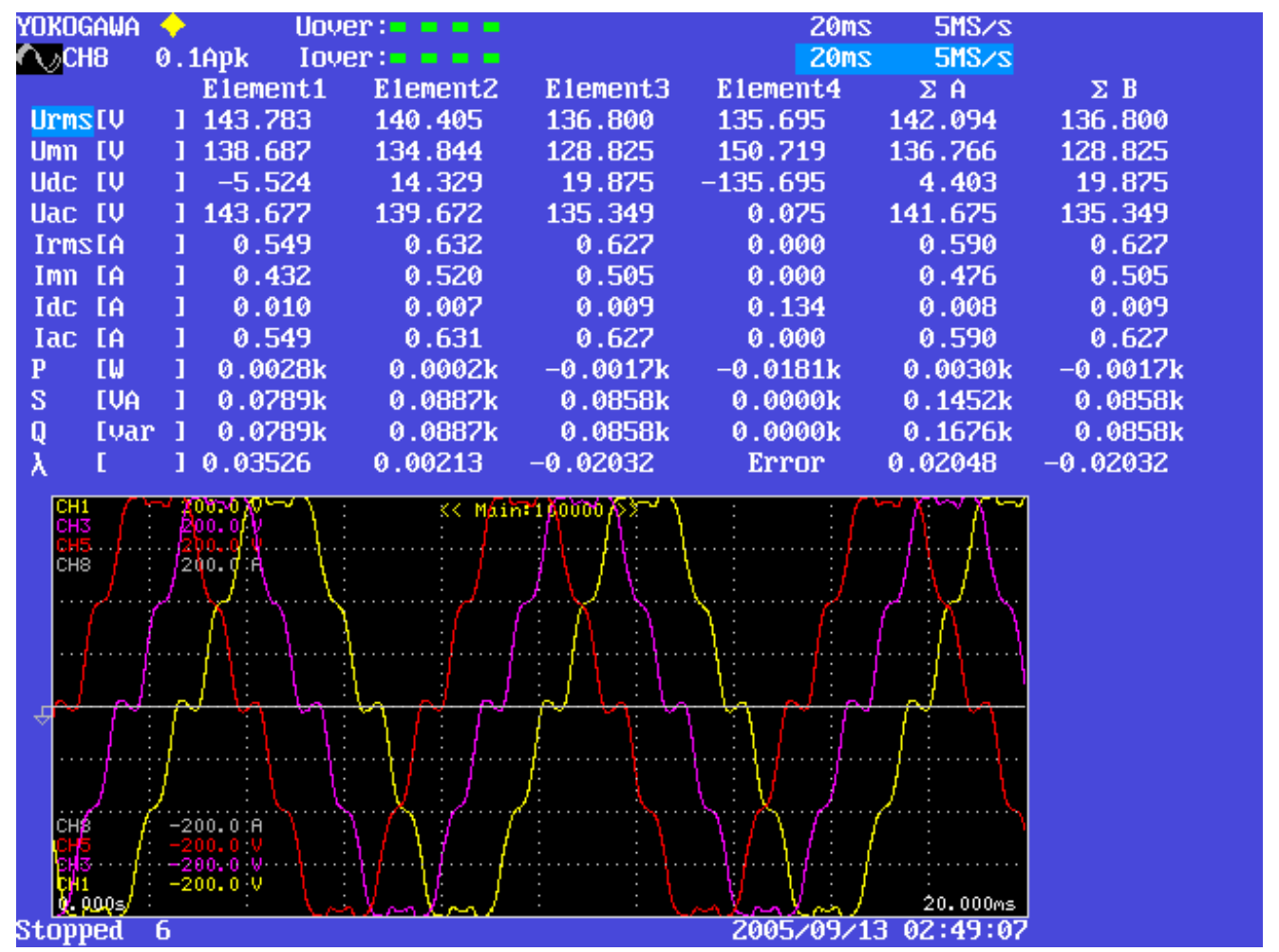

Fig. 70. 0.240 in. thick magnet rotor back-emf at $2000 \mathrm{rpm}$ with field enhancement at 3 Adc.

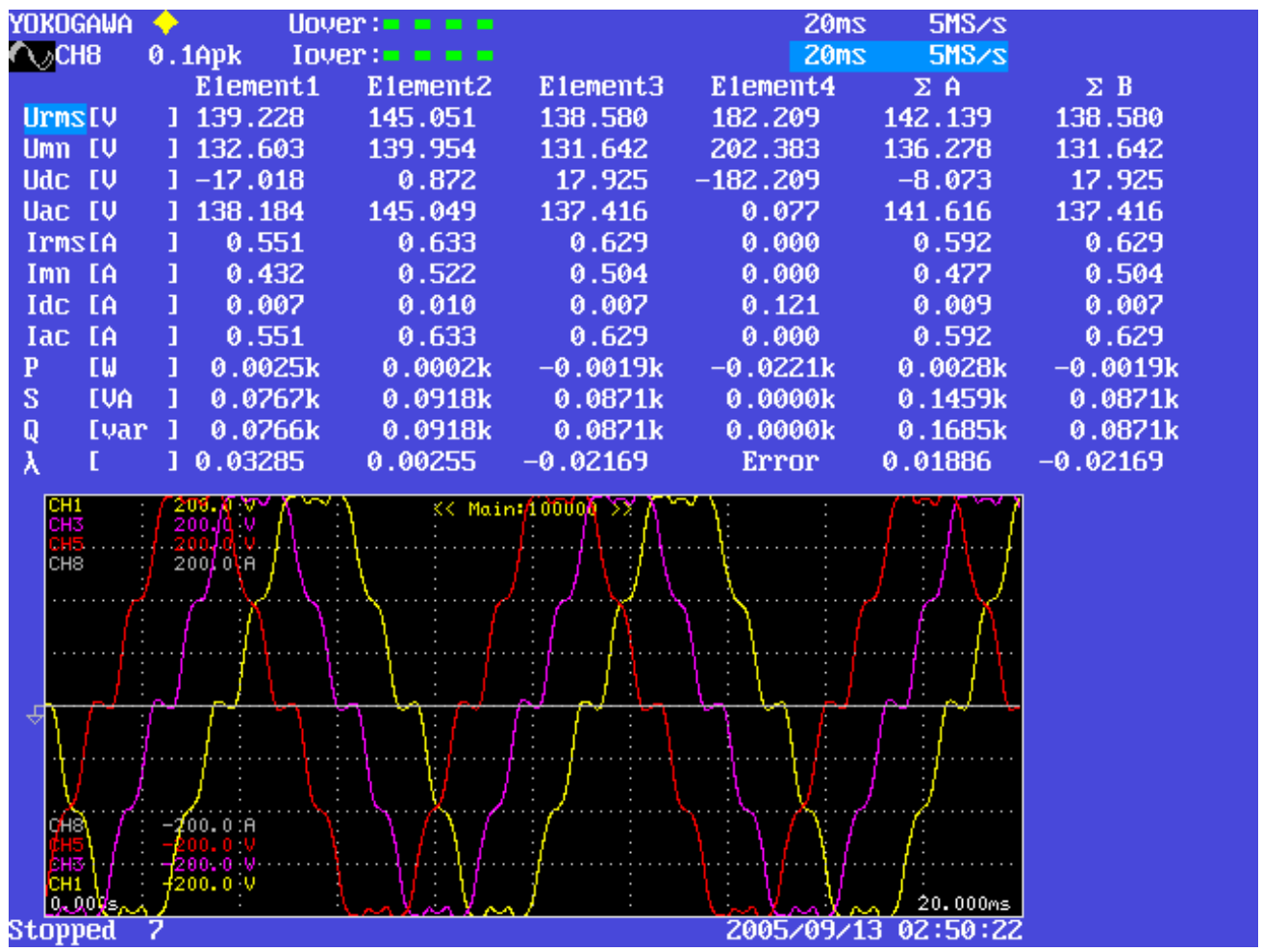

Fig. 71.0 .240 in. thick magnet rotor back-emf at $2000 \mathrm{rpm}$ with field enhancement at 4 Adc. 


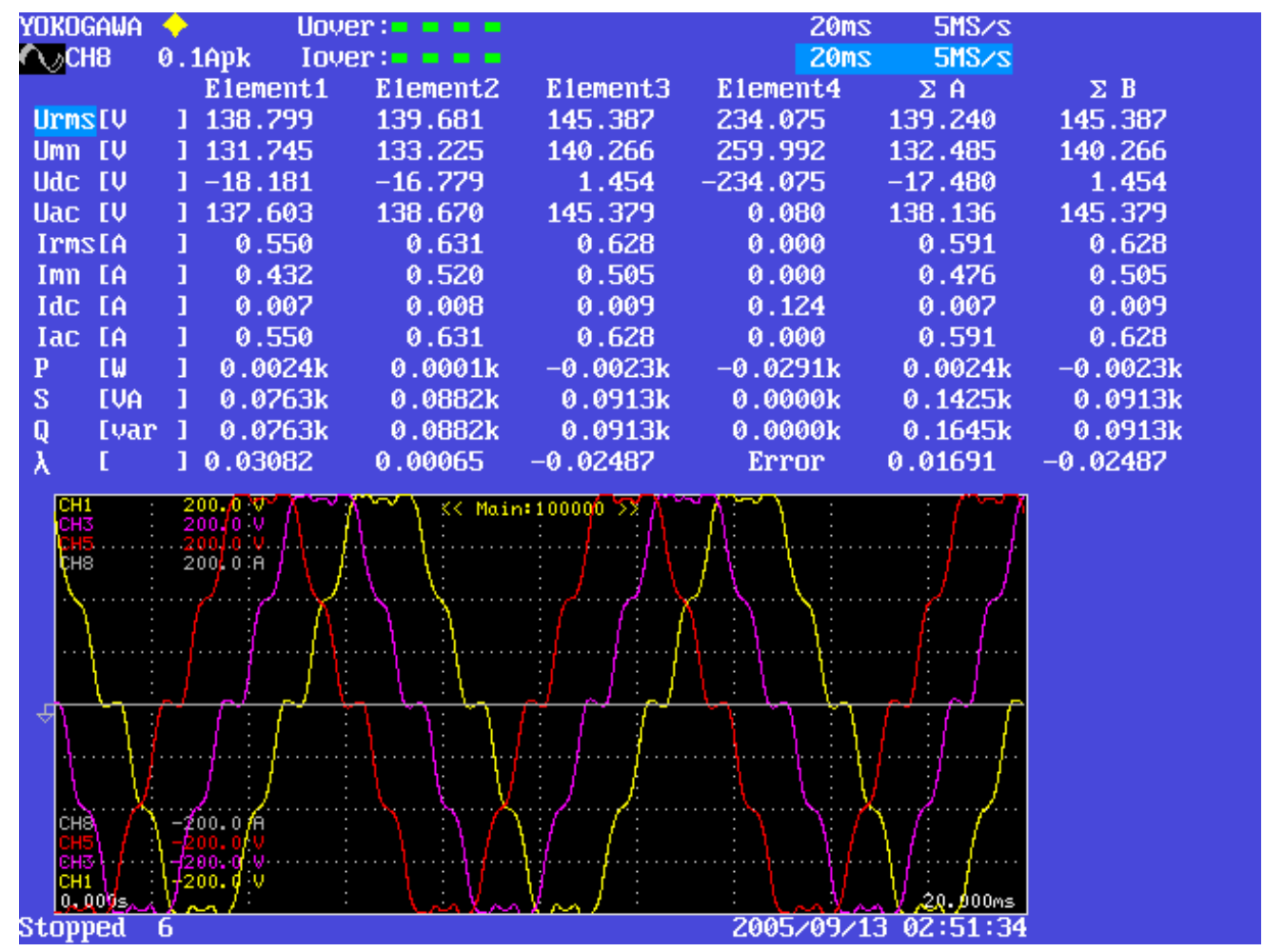

Fig. $72.0 .240 \mathrm{in}$. thick magnet rotor back-emf at $2000 \mathrm{rpm}$ with field enhancement at 5 Adc.

Mechanical losses were measured at 500-2000 rpm without field enhancement or weakening. The data collected and the calculated power loss is presented in Table 3.

Table 3. Mechanical losses on 0.240 in. magnet rotor at 500-2000 rpm without field enhancement/weakening

$\begin{array}{ccc}\text { Rpm } & \text { Torque } & \text { Loss }(\mathbf{W}=\mathbf{r p m * N m * ( 2 \pi / 6 0 )} \\ 500 & 0.8 \mathrm{Nm} & 42 \mathrm{~W} \\ 1000 & 0.95 \mathrm{Nm} & 99 \mathrm{~W} \\ 1500 & 1.10 \mathrm{Nm} & 173 \mathrm{~W} \\ 2000 & 1.15 \mathrm{Nm} & 241 \mathrm{~W} \\ 1500 & 1.0 \mathrm{Nm} & 157 \mathrm{~W} \\ 1000 & 0.9 \mathrm{Nm} & 94 \mathrm{~W} \\ 500 & 0.7 \mathrm{Nm} & 37 \mathrm{~W}\end{array}$

The RIPM-BFE machine containing the 0.240 in. thick magnets had locked rotor tests performed to determine the torque output on the motor shaft. The tests were conducted without field excitation and with excitation in both the weakening and enhancement state. The motor was excited with a direct current, sufficient enough for the rotor to "cog" to one of its four magnetic zero states. The output from the shaft encoder was then zeroed and the locked rotor tests began at this "zero" position. The stator was given currents of 50, 100, 150, 200, and 250 amps dc while being held in the "locked" position and torque readout was recorded. The motor was driven in 5 degree increments through a total of 45 degrees and the torque value at each level was recorded. The torque readings at each ampere level are represented in Tables 4-18 and 
Figs. 73-76. Highlighted information in each table represents the maximum torque value and its corresponding angular position at the respective stator amperage.

Table 4. Locked rotor torque of RIPM-BFE motor at 50 amps dc stator current

\begin{tabular}{ccccc}
$\begin{array}{c}\text { Rotor position } \\
\text { (degrees) }\end{array}$ & $\begin{array}{c}\text { Stator amperage } \\
\text { (dc) }\end{array}$ & $\begin{array}{c}\text { Stator voltage } \\
\text { (dc) }\end{array}$ & $\begin{array}{c}\text { Field excitation } \\
\text { amperage }\end{array}$ & $\begin{array}{c}\text { Torque reading } \\
\text { (Nm) }\end{array}$ \\
0 & 50 & 50 & 0 & 0.6 \\
5 & 50 & 50 & 0 & 17.05 \\
10 & 50 & 50 & 0 & 32.65 \\
15 & 50 & 50 & 0 & 34.40 \\
\hline 18.5 & 50 & 50 & 0 & 55.7 \\
20 & 50 & 50 & 0 & 51.50 \\
25 & 50 & 50 & 0 & 52.90 \\
30 & 50 & 50 & 0 & 38.75 \\
35 & 50 & 50 & 0 & 44.35 \\
40 & 50 & 50 & 0 & 28.45 \\
45 & 50 & 50 & 0 & 1.75
\end{tabular}

Table 5. Locked rotor torque of RIPM-BFE motor at 100 amps dc stator current

$\begin{array}{ccccc}\begin{array}{c}\text { Rotor position } \\ \text { (degrees) }\end{array} & \begin{array}{c}\text { Stator amperage } \\ \text { (dc) }\end{array} & \begin{array}{c}\text { Stator voltage } \\ \text { (dc) }\end{array} & \begin{array}{c}\text { Field excitation } \\ \text { amperage }\end{array} & \begin{array}{c}\text { Torque reading } \\ \text { (Nm) }\end{array} \\ 0 & 100 & 50 & 0 & 3.2 \\ 5 & 100 & 50 & 0 & 29.65 \\ 10 & 100 & 50 & 0 & 53.55 \\ 15 & 100 & 50 & 0 & 64.2 \\ 20 & 100 & 50 & 0 & 83.35 \\ 25 & 100 & 50 & 0 & 101.15 \\ 26.3 & 100 & 50 & 0 & 104.0 \\ 30 & 100 & 50 & 0 & 82.25 \\ 35 & 100 & 50 & 0 & 87.25 \\ 40 & 100 & 50 & 0 & 61.5 \\ 45 & 100 & 50 & 0 & 6.4\end{array}$

Table 6. Locked rotor torque of RIPM-BFE motor at 150 amps dc stator current

\begin{tabular}{ccccc}
$\begin{array}{c}\text { Rotor position } \\
\text { (degrees) }\end{array}$ & $\begin{array}{c}\text { Stator amperage } \\
\text { (dc) }\end{array}$ & $\begin{array}{c}\text { Stator voltage } \\
\text { (dc) }\end{array}$ & $\begin{array}{c}\text { Field excitation } \\
\text { amperage }\end{array}$ & $\begin{array}{c}\text { Torque reading } \\
\text { (Nm) }\end{array}$ \\
0 & 150 & 100 & 0 & 9.95 \\
5 & 150 & 100 & 0 & 36.6 \\
10 & 150 & 100 & 0 & 66.9 \\
15 & 150 & 100 & 0 & 80.8 \\
20 & 150 & 100 & 0 & 106.3 \\
25 & 150 & 100 & 0 & 134.85 \\
\hline 26 & 150 & 100 & 0 & 139.45 \\
30 & 150 & 100 & 0 & 118.6 \\
35 & 150 & 100 & 0 & 120.7 \\
40 & 150 & 100 & 0 & 91.9 \\
45 & 150 & 100 & 0 & 9.1
\end{tabular}


Table 7. Locked rotor torque of RIPM-BFE motor at 200 amps dc stator current

\begin{tabular}{ccccc}
$\begin{array}{c}\text { Rotor position } \\
\text { (degrees) }\end{array}$ & $\begin{array}{c}\text { Stator amperage } \\
(\mathbf{d c})\end{array}$ & $\begin{array}{c}\text { Stator voltage } \\
\text { (dc) }\end{array}$ & $\begin{array}{c}\text { Field excitation } \\
\text { amperage }\end{array}$ & $\begin{array}{c}\text { Torque reading } \\
\text { (Nm) }\end{array}$ \\
0 & 200 & 100 & 0 & 13.9 \\
5 & 200 & 100 & 0 & 41.6 \\
10 & 200 & 100 & 0 & 74.4 \\
15 & 200 & 100 & 0 & 90.7 \\
20 & 200 & 100 & 0 & 122.45 \\
25 & 200 & 100 & 0 & 160.6 \\
26.5 & 200 & 100 & 0 & 167.0 \\
\hline 30 & 200 & 100 & 0 & 143.95 \\
35 & 200 & 100 & 0 & 149.9 \\
40 & 200 & 100 & 0 & 118.05 \\
45 & 200 & 100 & 0 & 9.35
\end{tabular}

Table 8. Locked rotor torque of RIPM-BFE motor at 250 amps dc stator current

$\begin{array}{ccccc}\begin{array}{c}\text { Rotor position } \\ \text { (degrees) }\end{array} & \begin{array}{c}\text { Stator amperage } \\ \text { (dc) }\end{array} & \begin{array}{c}\text { Stator voltage } \\ \text { (dc) }\end{array} & \begin{array}{c}\text { Field excitation } \\ \text { amperage }\end{array} & \begin{array}{c}\text { Torque reading } \\ \text { (Nm) }\end{array} \\ 0 & 250 & 100 & 0 & 15.1 \\ 5 & 250 & 100 & 0 & 45.0 \\ 10 & 250 & 100 & 0 & 81.1 \\ 15 & 250 & 100 & 0 & 99.35 \\ 20 & 250 & 100 & 0 & 134.1 \\ 25 & 250 & 100 & 0 & 179.6 \\ 26.2 & 250 & 100 & 0 & 187.7 \\ 30 & 250 & 100 & 0 & 165.7 \\ 35 & 250 & 100 & 0 & 172.2 \\ 40 & 250 & 100 & 0 & 132.55 \\ 45 & 250 & 100 & 0 & 1.25\end{array}$

Table 9. Locked rotor torque of RIPM-BFE motor at 50 amps dc stator current with 5 amps field excitation (enhance)

\begin{tabular}{ccccc}
$\begin{array}{c}\text { Rotor position } \\
\text { (degrees) }\end{array}$ & $\begin{array}{c}\text { Stator amperage } \\
\text { (dc) }\end{array}$ & $\begin{array}{c}\text { Stator voltage } \\
\text { (dc) }\end{array}$ & $\begin{array}{c}\text { Field excitation } \\
\text { amperage } \\
\text { (enhance) }\end{array}$ & $\begin{array}{c}\text { Torque reading } \\
\text { (Nm) }\end{array}$ \\
0 & 50 & 50 & 5 & 6.55 \\
5 & 50 & 50 & 5 & 19.85 \\
10 & 50 & 50 & 5 & 41.2 \\
15 & 50 & 50 & 5 & 38.8 \\
20 & 50 & 50 & 5 & 59.85 \\
25 & 50 & 50 & 5 & 63.35 \\
26.45 & 50 & 50 & 5 & 66.8 \\
30 & 50 & 50 & 5 & 46.45 \\
35 & 50 & 50 & 5 & 54.9 \\
40 & 50 & 50 & 5 & 36.95 \\
45 & 50 & 50 & 5 & 0.8 \\
\hline
\end{tabular}


Table 10. Locked rotor torque of RIPM-BFE motor at 100 amps dc stator current with 5 amps field excitation (enhance)

\begin{tabular}{ccccc}
$\begin{array}{c}\text { Rotor position } \\
\text { (degrees) }\end{array}$ & $\begin{array}{c}\text { Stator amperage } \\
\text { (dc) }\end{array}$ & $\begin{array}{c}\text { Stator voltage } \\
\text { (dc) }\end{array}$ & $\begin{array}{c}\text { Field excitation } \\
\text { amperage } \\
\text { (enhance) }\end{array}$ & $\begin{array}{c}\text { Torque reading } \\
\text { (Nm) }\end{array}$ \\
0 & 100 & 50 & 5 & 0.85 \\
5 & 100 & 50 & 5 & 35.15 \\
10 & 100 & 50 & 5 & 65.2 \\
15 & 100 & 50 & 5 & 72.05 \\
20 & 100 & 50 & 5 & 102.15 \\
25 & 100 & 50 & 5 & 119.0 \\
26.9 & 100 & 50 & 5 & 123.1 \\
\hline 30 & 100 & 50 & 5 & 99.9 \\
35 & 100 & 50 & 5 & 106.95 \\
40 & 100 & 50 & 5 & 73.65 \\
45 & 100 & 50 & 5 & 3.75 \\
\hline
\end{tabular}

Table 11. Locked rotor torque of RIPM-BFE motor at 150 amps dc stator current with 5 amps field excitation (enhance)

\begin{tabular}{ccccc}
$\begin{array}{c}\text { Rotor position } \\
\text { (degrees) }\end{array}$ & $\begin{array}{c}\text { Stator amperage } \\
\text { (dc) }\end{array}$ & $\begin{array}{c}\text { Stator voltage } \\
\text { (dc) }\end{array}$ & $\begin{array}{c}\text { Field excitation } \\
\text { amperage } \\
\text { (enhance) }\end{array}$ & $\begin{array}{c}\text { Torque reading } \\
\text { (Nm) }\end{array}$ \\
0 & 150 & 100 & 5 & 5.7 \\
5 & 150 & 100 & 5 & 44.75 \\
10 & 150 & 100 & 5 & 81.75 \\
15 & 150 & 100 & 5 & 95.05 \\
20 & 150 & 100 & 5 & 131.35 \\
25 & 150 & 100 & 5 & 162.15 \\
26.6 & 150 & 100 & 5 & 170.6 \\
\hline 30 & 150 & 100 & 5 & 145.10 \\
35 & 150 & 100 & 5 & 146.2 \\
40 & 150 & 100 & 5 & 111.1 \\
45 & 150 & 100 & 5 & 10.6 \\
\hline
\end{tabular}

Table 12. Locked rotor torque of RIPM-BFE motor at 200 amps dc stator current with 5 amps field excitation (enhance)

\begin{tabular}{ccccc}
$\begin{array}{c}\text { Rotor position } \\
\text { (degrees) }\end{array}$ & $\begin{array}{c}\text { Stator amperage } \\
\text { (dc) }\end{array}$ & $\begin{array}{c}\text { Stator voltage } \\
\text { (dc) }\end{array}$ & $\begin{array}{c}\text { Field excitation } \\
\text { amperage } \\
\text { (enhance) }\end{array}$ & $\begin{array}{c}\text { Torque reading } \\
\text { (Nm) }\end{array}$ \\
0 & 200 & 100 & 5 & 11.8 \\
5 & 200 & 100 & 5 & 52.35 \\
10 & 200 & 100 & 5 & 94.6 \\
15 & 200 & 100 & 5 & 115.1 \\
20 & 200 & 100 & 5 & 156.3 \\
25 & 200 & 100 & 5 & 193.85 \\
26.75 & 200 & 100 & 5 & 202.1 \\
\hline 30 & 200 & 100 & 5 & 177.35 \\
35 & 200 & 100 & 5 & 179.8 \\
40 & 200 & 100 & 5 & 137.95 \\
45 & 200 & 100 & 5 & 11.4 \\
\hline
\end{tabular}


Table 13. Locked rotor torque of RIPM-BFE motor at 250 amps dc stator current with 5 amps field excitation (enhance)

\begin{tabular}{ccccc}
$\begin{array}{c}\text { Rotor position } \\
\text { (degrees) }\end{array}$ & $\begin{array}{c}\text { Stator amperage } \\
\text { (dc) }\end{array}$ & $\begin{array}{c}\text { Stator voltage } \\
\text { (dc) }\end{array}$ & $\begin{array}{c}\text { Field excitation } \\
\text { amperage } \\
\text { (enhance) }\end{array}$ & $\begin{array}{c}\text { Torque reading } \\
\text { (Nm) }\end{array}$ \\
0 & 250 & 100 & 5 & 13.4 \\
5 & 250 & 100 & 5 & 58.2 \\
10 & 250 & 100 & 5 & 105.05 \\
15 & 250 & 100 & 5 & 127.85 \\
20 & 250 & 100 & 5 & 175.85 \\
25 & 250 & 100 & 5 & 219.4 \\
26.6 & 250 & 100 & 5 & 228.0 \\
30 & 250 & 100 & 5 & 201.15 \\
35 & 250 & 100 & 5 & 207.3 \\
40 & 250 & 100 & 5 & 156.9 \\
45 & 250 & 100 & 5 & 13.8 \\
\hline
\end{tabular}

Table 14. Locked rotor torque of RIPM-BFE motor at 50 amps dc stator current with 5 amps field excitation (weaken)

\begin{tabular}{ccccc}
$\begin{array}{c}\text { Rotor position } \\
\text { (degrees) }\end{array}$ & $\begin{array}{c}\text { Stator amperage } \\
\text { (dc) }\end{array}$ & $\begin{array}{c}\text { Stator voltage } \\
\text { (dc) }\end{array}$ & $\begin{array}{c}\text { Field excitation } \\
\text { amperage } \\
\text { (weaken) }\end{array}$ & $\begin{array}{c}\text { Torque reading } \\
\text { (Nm) }\end{array}$ \\
0 & 50 & 50 & 5 & 0.5 \\
5 & 50 & 50 & 5 & 14.0 \\
10 & 50 & 50 & 5 & 29.0 \\
15 & 50 & 50 & 5 & 32.95 \\
20 & 50 & 50 & 5 & 46.8 \\
25 & 50 & 50 & 5 & 47.85 \\
26.05 & 50 & 50 & 5 & 49.1 \\
30 & 50 & 50 & 5 & 34.4 \\
35 & 50 & 50 & 5 & 41.3 \\
40 & 50 & 50 & 5 & 26.7 \\
45 & 50 & 50 & 5 & 1.95 \\
\hline
\end{tabular}

Table 15. Locked rotor torque of RIPM-BFE motor at 100 amps dc stator current with 5 amps field excitation (weaken)

\begin{tabular}{ccccc}
$\begin{array}{c}\text { Rotor position } \\
\text { (degrees) }\end{array}$ & $\begin{array}{c}\text { Stator amperage } \\
\text { (dc) }\end{array}$ & $\begin{array}{c}\text { Stator voltage } \\
\text { (dc) }\end{array}$ & $\begin{array}{c}\text { Field excitation } \\
\text { amperage } \\
\text { (weaken) }\end{array}$ & $\begin{array}{c}\text { Torque reading } \\
\text { (Nm) }\end{array}$ \\
0 & 100 & 50 & 5 & 3.85 \\
5 & 100 & 50 & 5 & 22.95 \\
10 & 100 & 50 & 5 & 47.55 \\
15 & 100 & 50 & 5 & 57.35 \\
20 & 100 & 50 & 5 & 76.45 \\
25 & 100 & 50 & 5 & 91.9 \\
\hline 26.5 & 100 & 50 & 5 & 96.0 \\
30 & 100 & 50 & 5 & 74.6 \\
35 & 100 & 50 & 5 & 82.5 \\
40 & 100 & 50 & 5 & 57.65 \\
45 & 100 & 50 & 5 & 6.05 \\
\hline
\end{tabular}


Table 16. Locked rotor torque of RIPM-BFE motor at 150 amps dc stator current with 5 amps field excitation (weaken)

\begin{tabular}{ccccc}
$\begin{array}{c}\text { Rotor position } \\
\text { (degrees) }\end{array}$ & $\begin{array}{c}\text { Stator amperage } \\
\text { (dc) }\end{array}$ & $\begin{array}{c}\text { Stator voltage } \\
\text { (dc) }\end{array}$ & $\begin{array}{c}\text { Field excitation } \\
\text { amperage } \\
\text { (weaken) }\end{array}$ & $\begin{array}{c}\text { Torque reading } \\
\text { (Nm) }\end{array}$ \\
0 & 150 & 100 & 5 & 7.05 \\
5 & 150 & 100 & 5 & 27.8 \\
10 & 150 & 100 & 5 & 56.9 \\
15 & 150 & 100 & 5 & 71.7 \\
20 & 150 & 100 & 5 & 98.05 \\
25 & 150 & 100 & 5 & 124.8 \\
26.73 & 150 & 100 & 5 & 131.8 \\
\hline 30 & 150 & 100 & 5 & 110.2 \\
35 & 150 & 100 & 5 & 115.4 \\
40 & 150 & 100 & 5 & 89.0 \\
45 & 150 & 100 & 5 & 9.3 \\
\hline
\end{tabular}

Table 17. Locked rotor torque of RIPM-BFE motor at 200 amps dc stator current with 5 amps field excitation (weaken)

\begin{tabular}{ccccc}
$\begin{array}{c}\text { Rotor position } \\
\text { (degrees) }\end{array}$ & $\begin{array}{c}\text { Stator amperage } \\
\text { (dc) }\end{array}$ & $\begin{array}{c}\text { Stator voltage } \\
\text { (dc) }\end{array}$ & $\begin{array}{c}\text { Field excitation } \\
\text { amperage } \\
\text { (weaken) }\end{array}$ & $\begin{array}{c}\text { Torque reading } \\
\text { (Nm) }\end{array}$ \\
0 & 200 & 100 & 5 & 9.3 \\
5 & 200 & 100 & 5 & 32.65 \\
10 & 200 & 100 & 5 & 66.05 \\
15 & 200 & 100 & 5 & 83.1 \\
20 & 200 & 100 & 5 & 114.85 \\
25 & 200 & 100 & 5 & 151.3 \\
26.7 & 200 & 100 & 5 & 158.9 \\
30 & 200 & 100 & 5 & 137.25 \\
35 & 200 & 100 & 5 & 145.75 \\
40 & 200 & 100 & 5 & 116.2 \\
45 & 200 & 100 & 5 & 11.75 \\
\hline
\end{tabular}

Table 18. Locked rotor torque of RIPM-BFE motor at 250 amps dc stator current with 5 amps field excitation (weaken)

\begin{tabular}{ccccc}
$\begin{array}{c}\text { Rotor position } \\
\text { (degrees) }\end{array}$ & $\begin{array}{c}\text { Stator amperage } \\
\text { (dc) }\end{array}$ & $\begin{array}{c}\text { Stator voltage } \\
\text { (dc) }\end{array}$ & $\begin{array}{c}\text { Field excitation } \\
\text { amperage } \\
\text { (weaken) }\end{array}$ & $\begin{array}{c}\text { Torque reading } \\
\text { (Nm) }\end{array}$ \\
0 & 250 & 100 & 5 & 10.8 \\
5 & 250 & 100 & 5 & 35.05 \\
10 & 250 & 100 & 5 & 73.05 \\
15 & 250 & 100 & 5 & 93.45 \\
20 & 250 & 100 & 5 & 127.4 \\
25 & 250 & 100 & 5 & 173.05 \\
26.9 & 250 & 100 & 5 & 182.3 \\
\hline 30 & 250 & 100 & 5 & 160.95 \\
35 & 250 & 100 & 5 & 173.25 \\
40 & 250 & 100 & 5 & 136.25 \\
45 & 250 & 100 & 5 & 17.15 \\
\hline
\end{tabular}




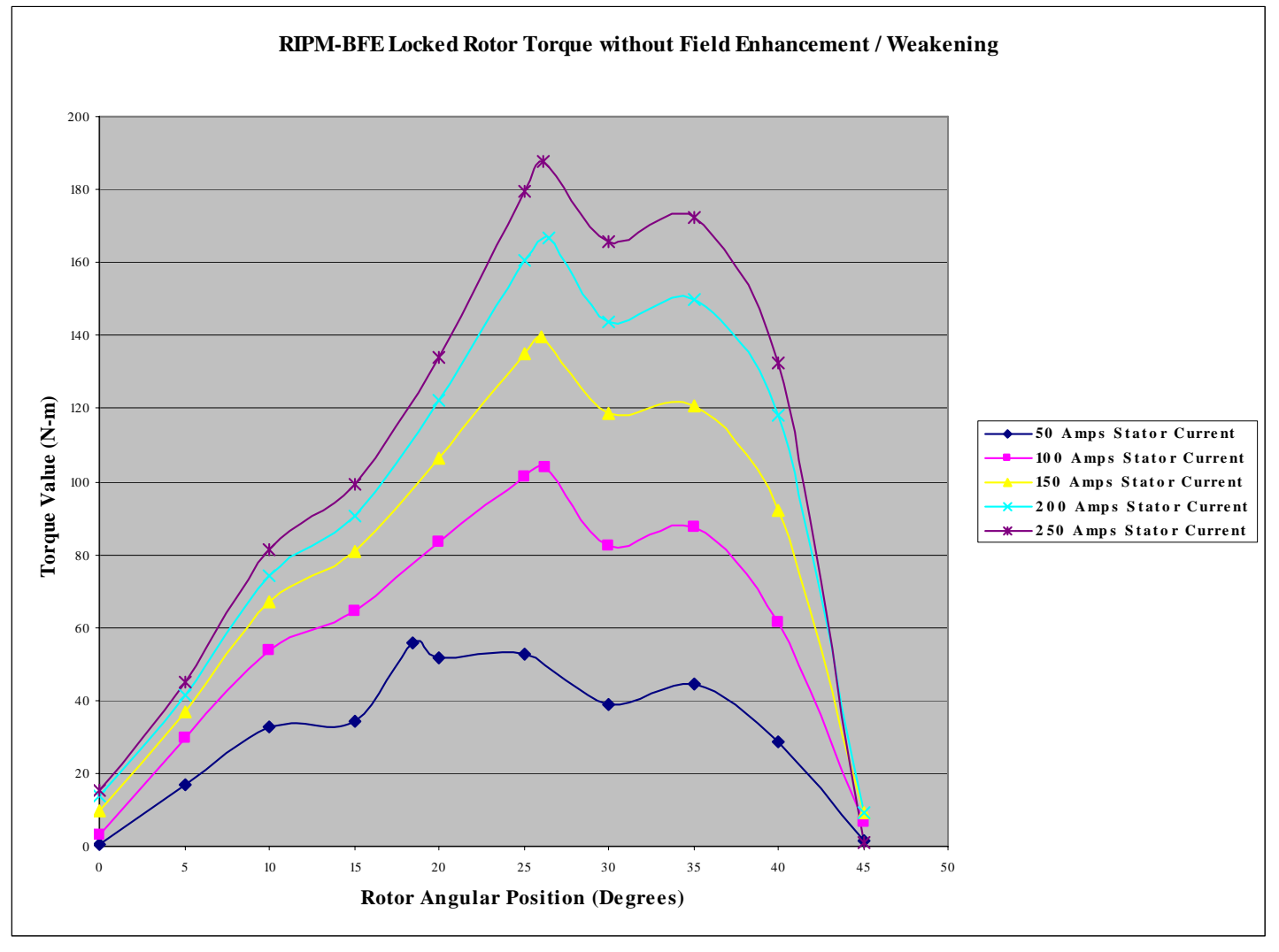

Fig. 73. RIPM-BFE locked rotor torque vs. rotor angular position without field enhancement/weakening.

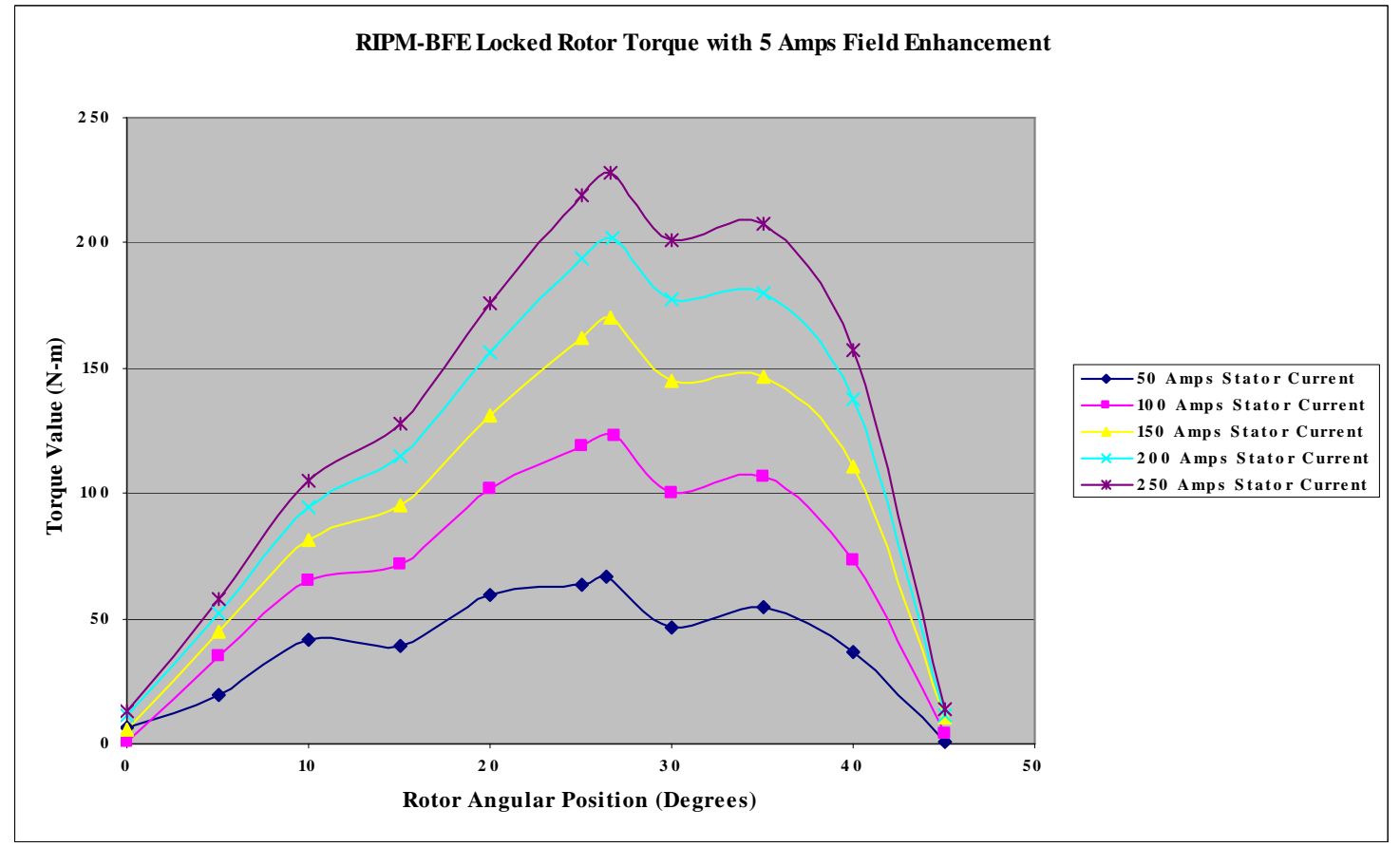

Fig. 74. RIPM-BFE locked rotor torque vs. rotor angular position with 5 amps field enhancement. 


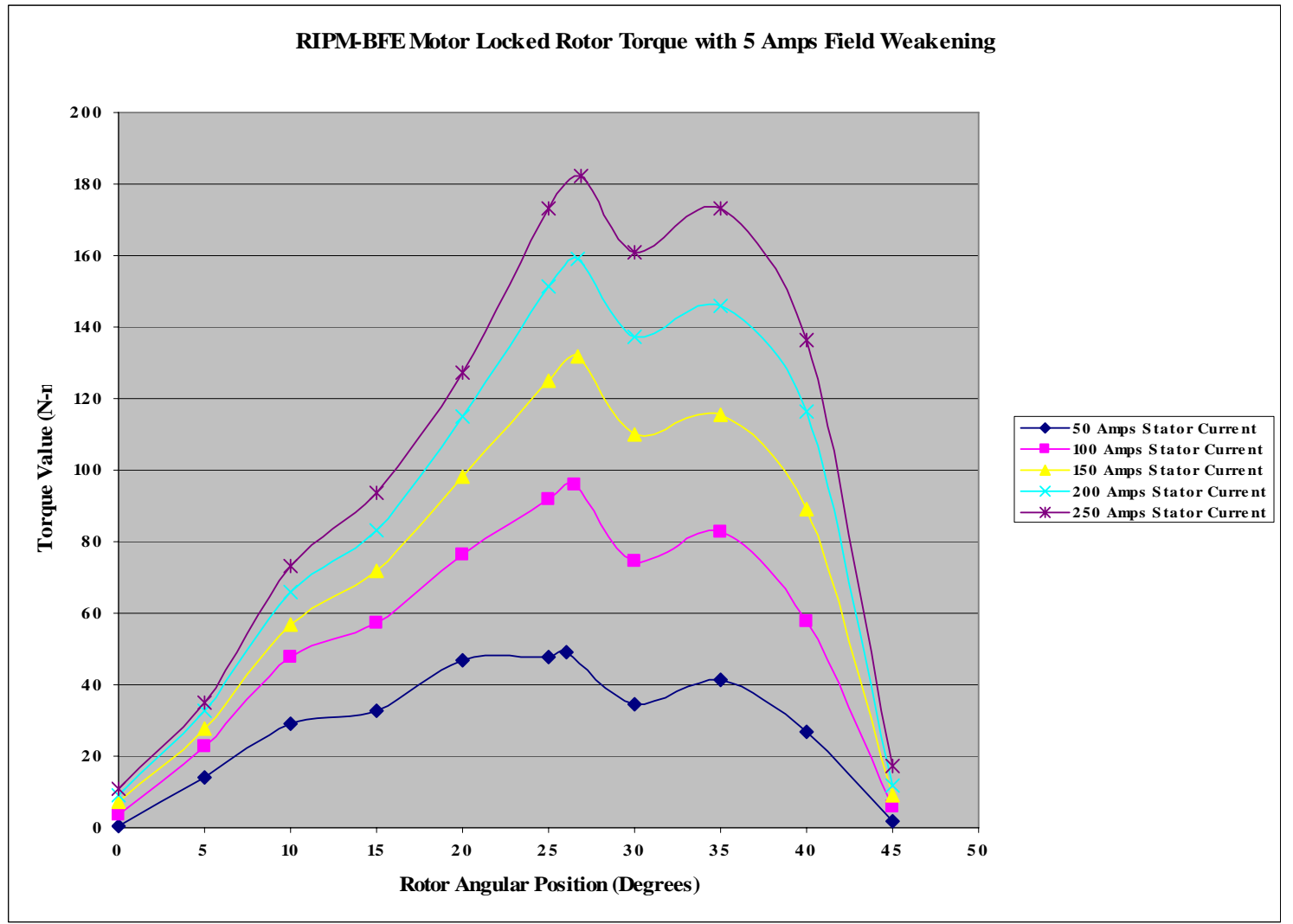

Fig. 75. RIPM-BFE locked rotor torque vs. rotor angular position with 5 amps field weakening.

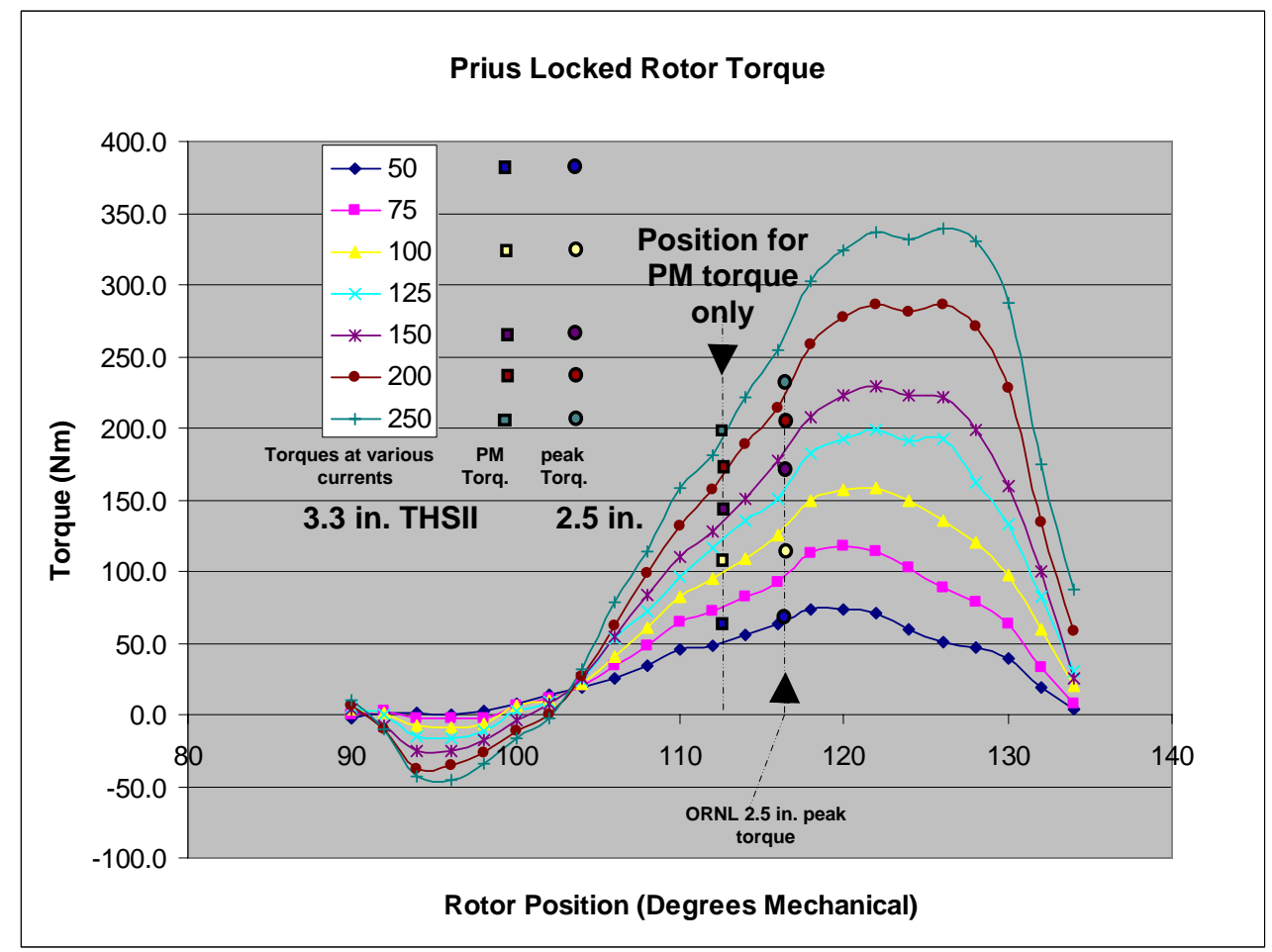

Fig. 76. Comparison of PM torque components and peak-torque components between 2.5 in. ORNL machine and 3.3 in. THSII machine. 


\section{CONCLUSIONS}

The ORNL RIPM-BFE motor has been simulated and built with a stator core length of 2.5 in., which is shorter than the 3.3 in. of the THSII stator core. The back-emf of the ORNL motor is higher than that of the THSII motor, which is indicative of the enhancement of the air-gap flux density in the ORNL motor. The ORNL PM torque component is slightly higher than that of the THSII motor at all stator current levels. The reluctance torque component of the ORNL motor is about the same at a low stator current of $50 \mathrm{amp}$. When the stator current increases to $250 \mathrm{amp}$, there is a significant difference between the ORNL motor and the THSII motor reluctance torque components. The ORNL motor requires further design modifications to deal with this saturation issue to achieve a higher-reluctance torque component at high-phase currents.

The RIPM-BFE motor is particularly suitable for short core length motors with weak PMs because the axial dc flux produced by the brushless stationary field winding can enter one end of the rotor axially and then distribute in the radial air gap for entry into the stator core. If the core length is long, the radial air gap area per pole can be much greater than the axial area per pole where the axial dc flux enters the rotor. For a given axial flux, the greater the radial area the lower the radial flux density, hence there will be a weaker influence of the excitation current on the radial air-gap flux density.

The concept of the ORNL RIPM-BFE motor has been proven. Future modifications of the design are required to optimize the motors performance. 


\section{DISTRIBUTION}

\section{Internal}

1. D. J. Adams

2. C. L. Coomer

3. E. C. Fox

4. K. P. Gambrell

5. J. S. Hsu
6. L. D. Marlino

7. M. Olszewski

8. R. H. Wiles

9-10. Laboratory Records

\section{External}

11. T. Q. Duong, U.S. Department of Energy, EE-2G/Forrestal Building, 1000 Independence Avenue, S.W., Washington, D.C. 20585.

12. R. R. Fessler, BIZTEK Consulting, Inc., 820 Roslyn Place, Evanston, Illinois 60201-1724.

13. K. Fiegenschuh, Ford Motor Company, Scientific Research Laboratory, 2101 Village Road, MD-2247, Dearborn, Michigan 48121.

14. V. Garg, Ford Motor Company, 15050 Commerce Drive, North, Dearborn, Michigan 48120-1261.

15. E. Jih, Ford Motor Company, Scientific Research Laboratory, 2101 Village Road, MD1170, Rm. 2331, Dearborn, Michigan 48121.

16. A. Lee, Daimler Chrysler, CIMS 484-08-06, 800 Chrysler Drive, Auburn Hills, Michigan 48326-2757.

17. F. Liang, Ford Motor Company, Scientific Research Laboratory, 2101 Village Road, MD1170, Rm. 2331/SRL, Dearborn, Michigan 48121.

18. M. W. Lloyd, Energetics, Inc., 7164 Columbia Gateway Drive, Columbia, Maryland 21046.

19. Brenda Medellon, USCAR, brenda@uscar.org

20. M. Mehall, Ford Motor Company, Scientific Research Laboratory, 2101 Village Road, MD-2247, Rm. 3317, Dearborn, Michigan 48124-2053.

21. J. Rogers, Chemical and Environmental Sciences Laboratory, GM R\&D Center, 30500 Mound Road, Warren, Michigan 48090-9055.

22. S. A. Rogers, U.S. Department of Energy, EE-2G/Forrestal Building, 1000 Independence Avenue, S.W., Washington, D.C. 20585.

23. G. S. Smith, General Motors Advanced Technology Center, 3050 Lomita Boulevard, Torrance, California 90505.

24. E. J. Wall, U.S. Department of Energy, EE-2G/Forrestal Building, 1000 Independence Avenue, S.W., Washington, D.C. 20585.

25. B. Welchko, General Motors Advanced Technology Center, 3050 Lomita Boulevard, Torrance, California 90505.

26. P. G. Yoshida, U.S. Department of Energy, EE-2G/Forrestal Building, 1000 Independence Avenue, S.W., Washington, D.C. 20585. 